\title{
CONTRIBUIÇÃO PARA O ESTUDO DO BORO DISPONIVEL EM SOLOS
}

\author{
VIRGILIO DE MORAES RUY \\ Engenheiro Agrônomo
}

Orientador : Prof. Dr. EURÍPEDES MALAVOLTA

Dissertação apresentada à Escola Superior de Agricultura "Luiz de Queiroz", da Universidade de São Paulo, para obtenção do título de Mestre em Agronomia - Área de Concentração: Solos e Nutrição de Plantas.

\footnotetext{
PIRACICABA

Estado de São Paulo - Brasil

Fevereiro - 1986
} 
.$e$.

A meus pais

DERVILLE E MARIA

DEDICO E OFEREÇO 


\section{AGRADEC IMENTOS}

- Ao Prof. Dr. Eurípedes Malavolta, pela orientação, incenti - vo e amizade durante todo o curso de mestrado;

- A Fundacão de Amparo à Pesquisa do Estado de São PauZo (FAPESP), pela bolsa de mestrado concedida;

- Ao Convênio FEALQ/FINEP, pela ajuda financeira;

- A.Profa. Dra. Clarice Garcia Borges Demëtrio, pelo auxílio nas anälises estatísticas;

- Aos colegas e funcionärios que conviveram comigo na Seg̃a de Nutrigão Mineral de Plantas do CENA, pelo auxilio, sü gestões e amizades;

- Aos amigos da Segão de Química Analïtica do CENA, pela co laboração prestada nas determinações analíticas;

- Ao amigo Alfredo José Ferraz de MeZZo, pela datilografia deste trabalho;

- A todos que di reta ou indiretamente contribuiram para o bom desenvolvimento da presente pesquisa. 
.iii.

TNDICE

Pägina

RESUMO .

SUMMARY.

1. InTROdUÇÃOO. . . . . . . . . . . . . . . . . . I

2. Revisão de literatura. . . . . . . . . . . . . . 4

2.1. Sintomas visuais de deficiencia de boro. . . . 4

2.2. Crescimento e composição mineral das plantas . 5

2.3. Boro do solo disponível às plantas. . . . . . 8

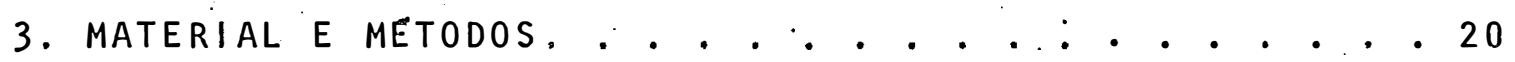

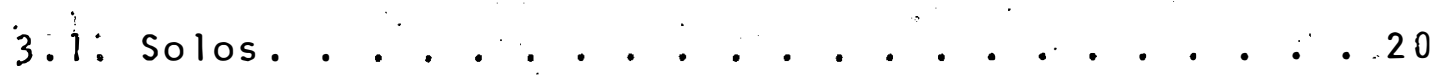

3.2. Amostragem e preparo dos solos....... 20

3.3. Anălises químicas............... . . 21

3.4. Anālises físicas. . . . . . . . . . 21

3.5. Determinação química do boro no solo. . . . . 22

3.5.1. Boro solúvel em ägua quente. . . . . 25

3.5.1.1. Extração......... . 25

3.5.1.2. Determinạ̧ão. . . . . . . 26

3.5.2. Boro solüvel em HCl 0,05 M..... . 26

3.5.2.1. Extração. . ...... . 26

3.5.2.2. Determinação. . . ... . . 27

3.5.3. Boro solúvel em acetato de amônio $1,0 \mathrm{~N}$,

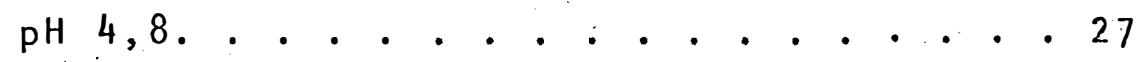

3.5.3.1. Extração. . . . . . . . 27

3.5.3.2. Determinação. . . . . . 28 
.iv.

3.6. Anālise do material vegetal........ . 28

3.7. Montagem e execução do experimento. . . . . 29

3.7.1. Delineamento experimental. .... . 29

3.7.2. Correção da acidéz dos solos. . : . . 29

3.7.3. Recipientes.......... . . 30

3.7.4. Fornecimento de nutrientes. . . . . . 30

3.7.5. Variedade de girassol utilizada. . . 30

3.7.6. Técnica experimental. . . . . . . . 33

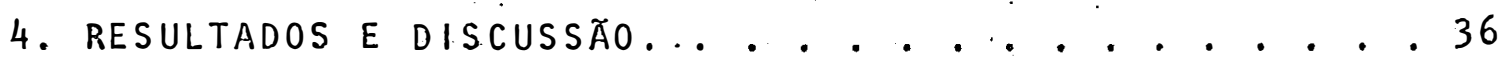

4.1. Sintomas visuais... . . . . . . . . 36

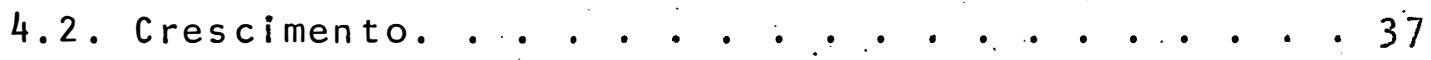

4.3. Composição mineral das plantas. ...... . . 42

4.3.1: Teores. . . . . . . . . . . 42

4.3.2. Quantidades absorvidas de boro em função da dose deste micronutriente. . . . 69

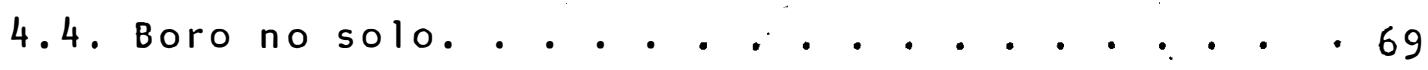

4.4.1. Teor inicial............ . . . 69

4.4.2. Teor final............ . 81

5. conclusóts. . . . . . . . . . . . . . . . . . 93

6. literatura citada. . . . . . . . . . . . 97 
CONTRIBUIÇAO PARA O ESTUDO DO BORO

DISPONIVEL EM SOLOS

\author{
Autor: VIRRILIO DE MORAES R.UY \\ Orientador: Prof. Dr. Eurípedes Malavolta
}

RESUMO

Com o propósito de avaliar a disponibilidade de boro, plantas de girassol (Helianthus annus Li) foram cultivadas em casa de vegetação utilizando solos de cinco séries (TRE, LR, LE, PVA e AQ) do município de Piracicaba, estado de São Paulo, Brasil. Foram aplicadas sete doses de boro, com quatro repetições, sob um esquema fatorial inteiramente casualizado.

0 mëtodo simplificado da ägua quente (GUPTA, 1967), o àcido clorídrico 0,05 M (PONNAMPERUMA et alii, 1981) e o acetato de amọnio 1,0 N, pH 4,8 (GUPTA e STEWART, 1975) foram empregados como soluções extratoras. 0 boro nos extra tos foi determinado pela técnica da curcumina quando empre gou-se as duas primeiras soluções e pela azometina quando se utilizou o $\mathrm{NH}_{4} \mathrm{AC} 1,0 \mathrm{~N}$, pH 4,8. 
.vi.

Durante a condução dó experimento foram realí. zadas medidas de crescimento e observados os sintomas de defi ciência de B. Após a colheita, executada 44 dias apōs a semea dura, foram realizadas análises minerais nas diversas partes das plantas.

Foram levados a efeito estudos de correlação. entre os teores iniciais e finais de B no solo, B absorvido pelas plantas de girassol e parâmetros de crescimento.

As principais conclusões foram as seguintes:

(1) A altura das plantas refletiu o estado nutr cional em relação ao boro melhor que qual quer outra característica das mesmas;

(2) Com relação à composição mineral as follias novas foram a parte da planta mais, sensível . à disponibilidade de boro;

(3) A extração com ăgua quente forneceu a me lhor indicação do B disponível do solo, sen do seguida com relação a este aspecto pelo HCl $0,05 \mathrm{M}$, os resultados obtidos com o $\mathrm{NH}_{4} \mathrm{AC} 1,0 \mathrm{~N}, \mathrm{pH} 4,8$ apresentaram menor con fiabi 1 idade; 
.vii.

(4) Para as três soluções extratoras foi possível estabelecer classes de fertilidade para o boro disponível do solo. 
CONTRIBUTION TO THE STUDY OF AVAILABLE

BORON IN SOILS

Author: VIRGILIO'DE MOPAES RUY

Adviser: Prof. Dr. Eurípedes Malavolta

\section{SUMMARY}

In order to assess boron availability sunflower (Helianthus annus L.) plants were grown in the greenhouse using soils belonging to five series of the Piracicaba County, State of S. Paulo, Brazil. Seven rates of B were applied with four replicates in a completely randomized design.

A simplified hot water technique (GUPTA, 1967), $0,05 \mathrm{M}$ hydrochloric acid (PONNAMPERUMA et ali $i, 1981$ ) and ammonium acetate buffered at pH 4,8 (GUPTA e STEWART, 1975) were employed as extracting solutions. In the extracts B was determined either by the curcumin. or by the azomethine technique.

During the course of the experiment which lasted for 44 days growth measurements were made and symptoms of deficiency were registered. After harvesting the plants mineral analyses were performed in the several parts thereof.

Correlation studies between initial and final $B$ in the soil, B taken up by the sunflower plants and growth 
parameters were conducted.

Main conclusions are the following:

(1) plant height reflected the nutritional status with respect to boron better than any other plant, characteristic;

(2) the $B$ content of younger leaves gave the best évaluation of the plant response insofar analyses of plant parts are concerned;

(3) hot water extraction provided the best indication of available $B$ in the soil, being followed in this respect by $0.05 \mathrm{M}$ HCl; results obtained with ammonium acetate were less reliable;

(4) it was possible to establish fertility classes for soil B using three extracting solutions. 


\section{INTRODUÇĀO}

Agrícola (1556); citado por BERGER (1949), menciona que o boro foi utilizado pela primeira vez com fina lidade fertilizante há quatrocentos arioś, através da aplica ção de börax, produto originärio da Āsia Central. BERGER(1949) ainda relata que apenas em 1857 foi constatado, por Witstein e Apoiger, a presença de boro nas cinzas de uma planta de no me Maesa picta, originária da Abissínia, pertencente à ordem Myrsinaceae. No entanto, segundo RUSSEL (1957), foi Waring ton no ano de 1923 quem forneceu a primeira prova conclusiva da essencialidade deste elemento para as plantas; anterior mente, no ano de 1915 , baseado num ensaio realizado com mi Iho em solução nutritiva, Mazé havia sugerido que o boro era essencial para a vida das plantas. 
Relatos sobre a ocorrência de deficiência de boro, bem como respostas das culturas à aplicação deste ele mento, já foram feitos há vários anos em quase todas as par tes do mundo, sendo que o Brasil não constitui exceção. Se gundo MALAVOLTA (1981) jả fóram constatadas deficiências de boro em doze estados brasileiros, para diversas culturas de real interesse econômico tai como: cana-de-açūcar, çafeei. ro, hortaliças, pinus, eucalipto, algodoeiro, batatinha, la ranjeira, macieira, mamoeiro e videira.

Devido à existência de um limite estreito en tre as concentrações deficientes e töxicas para o crescimen to normal das culturas, um programa de fertilização com boro requer planejamento cuidadoso. Necessita-se, primeiramente, so lucionar alguns problemas relacionados com os testes realiza dos para avaliar o boro existente no solo que está dispon vel às plantas. Os problemas geralmente se encaixam em duas categorias: são problemas de análise e interpretação. os pro blemas analiticos estão relacionados com os reagentes utili zados para a extração e determinação do boro; problemas en volvendo interpretação incluem a calibração da anälise do. so lo com as respostas das culturas.

o método da ägua quente, mais utilizado para a extração do boro do solo que está em formas disponíveis às plantas, por apresentar uma sērie de problemas, estä longe 
de ser apropriado para anälises rápidas de rotina. GUPTA e STEWART (1975) e PONNAMPERUMA et alii (1981) propuseram no vos procedimentos para a extração e determinação do boro que apresentaram nos trabalhos originais vantagens sobre o méto do da ägua. quente.

A presente pesquisa teve como objetivos:

- verificar o efeito de doses crescentes de boro no cresci - mento e na composição mineral de plantas de girassol;

- estabelecer curvas de calibração para trés extratores do boro do solo que está disponível às plantas: HCl 0,05 $\mathrm{M}$, acetato de amônio $1,0 \mathrm{~N}, \mathrm{pH} 4,8$ e àgua quente (mëtodo sim plificado);

- estudar como os três extratores se inter-relacionam;

- relacionar os teores de boro disponivel do solo fornecido pelos três extratores com o teor deste elemento nas diver sas partes da planta e com a quantidade de boro absorvida pelas plantas de girassol. 


\section{REVISĀO DE LITERATURA}

\subsection{SinTOMAS VISUAIS DE DEFICIÊNCIA DE BORO}

$$
\text { Segundo BRASIL SOBRINHO (1965) e CASAGRANDE }
$$

(1978) os sintomas de deficiência de boro em girassol podem ser classificados em diferentes estadios: inicialmente desen volve-se uma levé clorose na base das folhas terminais da planta (início); a seguir a clorose torna-se bem definida (1 a fase). Com o progredir dos sintomas, alēm da clorose do primeiro par, o segundo par de folhas torna-se verde-brilhan te ou com clorose na parte da base e coloração verde-brilhan te na parte restante do 1 imbo ( $2^{a}$ fase). Num estádio mais avançado há morte da gema terminal e paralisação do cresci mento da planta, acentuando-se os sintomas das folhas mais

novas $\left(3^{a}\right.$ fase). Em casos de deficiências extremas ocorre.a 
morte da gema apical logo no início do desenvolvimento da planta permanecendo apenas as folhas cotiledonares, as quais crescem exageradamente tornando-se disformes e com aspecto coriäceo, o tronco mostra entumecimento podendo ocorrer ra chaduras na altura do colo. Em condições de campo BLAMEY et alii (1979) relatam que a adição de boro à cultura de giras sol, crescendo em solos onde a deficiência deste micronu. triente jä tinha sido anteriormente constatada, teve um pe queno efeito visível nos estádios iniciais de crescimento das plântulas de girassol, entretanto, com o progredir do de senvolvimento das plantas foram observados clorose, necrose e consistência coriācea das folhas superiores nos tratamen tos onde o boro não foi aplicado.

\subsection{CRESCIMENTO E COMPOSIÇĀO MINERAL DAS PLANTAS}

SCHUSTER E STEPHENSON (1940) apös o cultivo de diversas plantas de girassol em vasos com 400 gramas de terra, aos quais tinham sido adicionados todos os elementos essenciais com exceção do boro, observaram que o peso da ma téria seca e a altura das plantas no final do experimento re velavam a disponibilidade de boro no solo.

CASAGRANDE (1978) verificou com base no cres cimento de plantas de girassol, cultivadas em vasos com meio litro de terra fina seca ao ar proveniente de cinco séries 
de solos do município de Piracicaba, que a aplicação de 0,3 e 0,4 ppm de $B$ foram suficientes para o desenvolvimento nor mal do girassol em relação ao peso da matéria seca e à altü ra, respectivamente. 0 auțor aindá relata que a utilização do peso da matéria seca como critério para avaliar a dispon bilidade de boro não foi tão eficiente quanto o valor-idade e a altura das plantas, sendo que estes dois ültimos. crité rios refletiram com boa precisão as faixas dos teores do bo ro do solo extraídos por meio do método da āgua quente.

BLAMEY et alii (1979) constataram um aumento de $48 \%$ na produção de sementes por. plantas de girassol, cul tivadas em condições de campo, como resposta à adição de bo ro. Por sua vez MESQUITA FILHO e OLIVEIRA (1984) obtiveram; em ensaio de casa de vegetação com solo sob vegetação de ce r rado, que à produção de matéria seca peila batata (Solanum tu berosum L.I, os teores de boro das follhas e dos solos aumen taram à medida que foram adicionadas doses crescentes do mi cronutriente; sendo que os teores de boro nas folhas não a mentaram proporcionalmente ao aumento da dose de boro. Jä PETERSON e NEWMAN (1976) observaram que a concentração de bo ro nas folhas de festuca (Festuca arundinacea Schreb) variou de 8 a 739 ppm para cinco cortes, sendo significativamente a fetada pela taxa de aplicaçäo de boro nos cinco cortes, vis to que cada incremento adicional de boro fornecido mais que 
dobrou a concentração do micronutriente no tecido foliar em todos os cortes efetuados.

Segundo HANWAY (1973), para alguns nutrien tes, a anälise de solo pode não ser possível ou exequível com resultados satisfatórios. Neste caso as análises de plan tas podem, muitas vezes, serem utilizadas para fornecer indi ces do estado nutricional em relação aos nutrientes em ques tão, ou mesmo para suplementar as informações para os nutri entes cuja anălise química nos solos é feita com suceśso. No caso do boro, jă foram encontradas por HIROCE $\in$ t alii (1971) correlações significativas entre o. teor de boro nas folhas e a produção de tubérculos de batatinha (Solanum tuberosum L:). Por outro lado BERGER e TRUOG (1940), baseados em correla. ções obtidas entre o boro extraído por meio da âgua quente e o teor de boro existente em folhas de beterraba, haviam su gerido que a análise de tecidos das plantas era um método promissor para determinar a disponibilidade de boro nos so los. BAKER e COOK (1959) relatam que a anălise do tecido das plantas com relação ao boro moströu ser um indicador melhor que o teor de boro no solo, extraído pelo método da água quente, para avaliar o boro do solo disponível às plantas. 
- GUPTA e MacLEOD (1977) não obtiveram efeito significativo de doses de boro sobre as concentrações de cā cio e magnésio nos tecidos de alfafa e nabo. ELLIOTT e NELSON (1981) fornecendo boro a intervalos regulares até o apareci mento de toxidez deste micronutriente em plantas de begōnia (Begonia hiemalis), cultivadas em vasos, não observaram nas folhas novas destas plantas, quando comparadas a plantas de mesma idade que não receberam boro, efeito deste nutriente so. bre os teores foliares de nitrogēnio, fósforo, potássio, cā cio, magnésio, cobre, ferro, manganēs e zinco, tendo sido ob servado efeito marcante de doses de boro sobre os teores des. te elemento nas folhas.

\section{3; BORO DO SOLO DISPONIVEL ȦS PLANTAS}

De acordo com WALSH e BEATON (1973) os proce dimentos analíticos para medir as frações disponíveis de mi cronutrientes do solo necessitam novas pesquisas. A grande maioria dos pesquisadores tem dado preferência à utilização da ägua quente como extrator do boro existente no solo que estā em formas disponíveis às plantas, mëtodo proposto por BERGER e TRUOG (1939). Segundo BRAY (1948) para que a análise química do solo alcance sucesso é necessārio empregar uma so lução extratora que possua as seguintes propriedades: a) extrair a 
quantidade total ou proporcional das formas disponiveis do nu triente de solos com propriedades variáveis; b) medir com ra zoăvel precisão a quantidade do nutriente no solo e, c) pos suir rapidez e precisão. GUPTA e STEWART.(1975) citam fatos pelos quais concluem que a água quente não possui as proprie dades sugeridas por BRAY (1948); segundo os autores descri ções recentes do método de extração de boro do solo por meio da àgua quente mostram algumas variações. entre laboratórios, sejam estes localizados em paises diferentes ou num mesmo país, que dificultam a comparação dos resultados embora o extrator seja o mesmo. GUPTA e STEWART (1975) relatam vários problemas e desvantagens relacionados com o uso deste extrator, tais. có mo morosidade da análíse, procedimento muito trabalhoso, pos sibilidade de aparecimento de filtrados turvos e perda de bo ro na forma de vapor. Para MELSTED e PECK (1973) a anālise do solo é aplicada em praticamente todas as partes do mundo com sucesso variāvel; as causas do sucesso ou fracasso são di versas mas, geralmente, éstão relacionadas com a quantidade e a qualidade dos dados de pesquisa disponiveis para a calibra ção e interpretação destas anālises.

BRAY (1948) considera que o valor obtido na anālise de solo deve ser uma medida de duas propriedades in ter-relacionadas do mesmo, ou seja, a severidade da deficiên cia, isto é, como crescerá a produção se a deficiência do nu triente for corrigida e a quantidade de fertilizante requer 
da para corrigir esta deficiência; o processo experimental no qual estas duas propriedades do solo são estabelecidas e com binadas para fornecer a base para recomendação de fertilizan tes é chamado calibração da anālise de solo. Para COPE e HOU SE (1973) o objetivo da anālise química do solo é fornecer um guia para o manejo da fertilidade do mesmo, através da utili zação de relações determinadas experimentalmente entre proprie dades químicas dos solos e crescimento das culturas. Segundo os autores o processo de determinar as relações solo/colheita é comumente chamado de calibração dos valores da análise quI mica do solo; um valor calibrado da anälise de solo para um nutriente particular deve indicar o grau de deficiência deste nutriente e a quantidade do mesmo que deve ser aplicada como fertilizante. para corrigir esta deficiência. Por outro lado WALSH e BEATON. (1973) relatam que existem dūvidas sobre os significados dos termos calibração e correlação, existindo uma tendência dos mesmos serem empregados como sinônimos. Pa ra WALSH e BEATON (1973) o termo correlação deve ser usado pạ ra expressar a relação entre as quantidades extraídas pelos testes de laboratório e a absorção pelas plantas, sendo o ter mo calibração entendido como a relação entre testes de labora tōrio e valores de produção para doses crescentes do nutrien te em estudo.

o princípio bäsico para verificar se o solo 
.11.

estä deficiente, segundo BRAY (1948), ë a existência de um tratamento onde nenhum dos nutrientes está deficiente ou em quantidades töxicas ao lado de outro tratamento em condições semelhantes, onde o nutriente em estudo é omitido. HANWAY(1973) tambēm se refere a este aspecto relatando que nos éstudos em casa de vegetação é importante que todos os nutrientes essen ciais, exceto o que está em falta, estejam disponíveis em con dições adequadas. Ainda segundo BRAY (19.48) para se saber o nível da deficiência é necessārio trabalhar com doses crescen tes do nutriente em estudo até se atingir o tratamento comple to.

ROUSE (1968) relata que nos ensaios visando obter dados destinados'à calibração as condições experimen tais variam muito, não se podendo utilizzar as produções reais como base de comparação. As produções obtidas como respostas às diferentes doses do nutriente podem ser comparadas através da conversão das produções reais em produções relativas: a produção mais alta deve ser tomada como um valor 100 e todas as outras produções daquele solo devem ser relaciona das com a mais alta. No entanto, BRAY (1948) considera que to dos os solos devem receber uma quantidade igual do nutriente em estudo que serä suficiente, mesmo nos solos mais pobres, para atingir a produção mäxima, sendo a produção relativa de todos os solos expressas em relação à produção com 
.12.

este teor comum. WALMSLEY et alii (1971) tambëm relatam que as produções relativas devem ser calculadas com relação à uma produçăo mäxima obtida com um parâmetro comum.

A relação entre valores de anālise química de solo e niveis de fertilidade do mesmo são usualmente des critas com base nos termos baixo, médio e alto. No entanto, segundo ROUSE (1968), para a pälise de solos ser quantitati va os termos utilizados para descrever os teores devem ser de finidos em termos de suficiência para o crescimento das plan tas. 0 autor adota os seguintes niveis de fertilidade: a) ex cessivamente alto - significa uma quantidade excessiva do nu triente no solo, sendo que adições futuras podem ser prejudi ciais; b) muito alto - significa que o fornecimento do nutri ente é adequado, sendo que adições futuras não devem ser fei tas enquanto a anälise do solo não mostrar uma queda no teor do elemento; $\dot{c}$ ) alto - significa que o fornecimento do nutri ente é adequado para as produçöes mais elevadas, no entanto, è vantajoso iniciar uma adubação leve (de manutenção) pàra conservar alto o nível de fertilidade; d) médio - significa que o solo poderá produzir de 75 a $100 \%$ da produção potencial sem a adição do elemento; e) baixo - significa que o solo po derá produzir de 50 a $75 \%$ da produção potencial sem a adição do elemento e,f) muito baixo - significa que o solo poderä produzir menos que $50 \%$ da produção potencial sem a adição do 
elemento. Para eliminar o sinal de porcentagem ROUSE (1968) es tabeleceu indices de fertilidade, que são os seguintes: a) me nor. que 50 - corresponde a mui to baixo; b) 50-75 - baixo; c) 75-100 - médio; d) 100-300 - alto; e) 300-600 - muito alto e, f) maior que 600 - excessivamente alto. Por outro lado, RAl (1974) considera que o uso de cinco classes de teores têm a vantagem de diminuir os riscos de erro na formulação de adu bos devido a desvios imprevistos da calibração estabelecida. outra vantagem é que as classes tendo sido estabelecidas com base na produção relativa, refletem melhor a produção que de ve ser esperada sem adubação com o nutriente em estudo do que utilizando-se apenas duas ou três classes. Sagundo o autor oś limites de classes são dados pela produção relativa que varia de 0 a $50 \%$ para teores muito baixos, 51 a $75 \%$ para teores ba xos, 76 a $90 \%$ para teores médios, 91 a $100 \%$ para teores altos e acima de $100 \%$ para teores muito altos, sendo que a produção relativa é calculada pela rélação entre a produção do trata mento que não recebeu o nutriente e um tratamento completo co mum a todos os solos.

RAIJ (1981) relata que um tipo de estudo mui to interessante para selecionar métodos de análise de solo consiste em conduzir ensaios em vasos com amostras de diver sos solos provenientes da.região, variando bastante naquelas propriedades que afetam a disponibilidade do nutriente em ques tão. Os solos devem receber todos os nutrientes necessärios 
para o desenvolvimento vegetal, menos o que está em teste. Uma planta è cultivada admitindo-se como ūnico fator a afe tár o crescimento a disponibilidade do nutriente testado no solo. Colhem-se as plantas e determinam-se as quantidades ab sorvidas do nutriente. Determina-se o nutriente em amostras dos mesmos solos, separadas antes do ensaio, por vários méto dos. Estudos de correlação entre teores dos nutrientes dos solos, determinados pelos diversos métodos, e as quantidades absorvidas pelas plantas indicarão as melhores possibilida des. O autor ainda relata que alguns outros critērios que têm influência na escolha de um método de anālise de solo são a facilidade de execução analitica, custo e uniformidade entre diversos laboratórios. Para RAlJ (1981) a vantagem de se utilizar produções relativas no estabelecimento de corré lações entre respostas às adubações e teores de nutrientes em solos está na minimização dos efeitós das condições climä ticas, que influem na produtividade e, portanto, nas respos tas em termos absolutos, mas afetam pouco as produções rela tivas.

BRASIL SOBRINHO (1965) encontrou coeficien te de correlação linear igual a $0,76^{* *}$ enitre altura e boro extraído por meio da água quente para os grandes grupos de solos do estado de São Paulo, sendo que para as séries do mu nicípio de Piracicaba o coeficiente foi igual a $0,79^{* *}$. CASE GRANDE (1978) encontrou para as séries do município de pira 
cicaba coeficiente de correlação linear entre altura e boro extraído por meio da ägua quente igual a $0,85^{* *}$. Com relação ao teor de boro solüvel em àgua quente e peso da matēria se ca produzida por plantas de gi rassol BRASIL SOBRINHO encontrou $r^{\prime}=0,80^{* *}$ tanto para os grandes grupos de solos do estado de São Paulo como para as sëries de solos do mun cípio de Piracicaba, para estas ültimas CASAGRANDE (1978) en controu $r^{\prime}=0,79^{* *}$.

OKAZAKI e CHAO (1968), estudando a adsorção e dessorção de boro por solos do Havai, levantaram uma crit i ca ao método de àgua quente. Chegoüse à conclusão de que o boro, provavelmente; forme durante o: processo de... adsorção mais de um produto de reação, istó porque a liberação do bo ro adsorvido mostrou a não reversibilidade total do processo de adsorção. A dessorção do boro foi influenciada pelo perío do de aquecimento da suspensão, pela relação sọlo-ägua e pẹ 10 nūmero de extrações. Segundo os autores, longos períodos de aquecimento, elevadas relações solo-ägua e maior nūmero de extrações tendem a aumentar a recuperação do boro nativo ou do boro adicionado. Com estes resultados contestou-se o fato da quantidade de boro extraída uma única vez com ăgua quente ser considerada disponivel para as plantas, ou seja, esta ex tração quando muito libera uma porção de boro que pode não ser proporcional à quantidade totál disponível presente na solução do solo, sendo que seria mais significativo conside 
rar a quantidade de boro, retirada em uma ünica extração com ägua quente como indicadora do rator intensidade e o boro to tal disponível, ou seja, o liberadó em repetidas extraçó̀es, como indicador do fator capacidade.

BAKER (1971) obtevé uma medida do boro bio logicamente disponínel analisando a quantidade removida de um pequeno volume do solo por plantas de girassol. A quanti dade de boro extraída do solo pela àgua quente, antes do plantio, foi bem correlacionada com o boro absorvido pelas plantas de girassol. 0 autor ainda obteve que as quantidades de boro extraídas quimicamente, calculadas através dos teo res de boro obtidos antes e após.o cultivo de cinco plantas de girassol por vaso com $500 \mathrm{ml}$ de terra fina seca ao ar at $\bar{\epsilon}$ todas as plantas mostrarem os sintomas de deficiência deste micronutriente, pelo método da ägua quente foram inferiores às quantidades extraídas pelas plantas. Por outro lado Mc CLUNG e DAWSON (1950), analisando o solo antes e após o cu! tivo de girassol em vasos, notaram que o decréscimo no con teúdo de boro solüvel em àgua quente foi relátivamente menor que as quantidades absorvidas pelas plantas, o que os levou a afirmar que este processo de extração removia apenas uma fração do boro que estaria em formas disponíveis às plantas. PETERSON e NEWMAN (1976) constataram que o boro extraido PE la ägua quente após o cultivo de festuca lFestuca ardindinacea Schreb) foi positivamenté relacioṇado com a taxa de adição 
de boro.

GUPTA e STEWART (1975), que propuseram, o acetato de amônio $1,0 \mathrm{~N}, \mathrm{pH} 4,8$ como extrator do boro dispo nível às plantas, realizaram um experimento comparando a efí ciência desta solução com a da água quente. os dois métodos não extraíram a quantidade total de boro, que tinha sido pre viamente adicionada aos solos, devidóà adsorção que ocorre nos componentes do solo (sesquiōxidos, argila e matéria orgâa nica). No entanto, a ägua quente extraiu menor quantidade de vido às perdas de boro na forma de vapor. os autores expli cam o ocorrido relatando que o método da água quente utiliza temperaturas ao redọr de $100^{\circ} \mathrm{C}$, ao passo que a extração com acetato de amônio se realiza à temperatura ambiente; a 103 ${ }^{\circ} \mathrm{C}$ a pressão de vapor do ácido bōrico aproxima-se da pressão atmosférica, sendo que a presença de grandes quantidades de sais pode aumentar o ponto de fusão da āgua, pelo que se de duz que durante a extração pela āgua quente há uma grande tendência do ácido bổrico escapar para a atmosfera na forma de vapor. RUSSEL (1957). tambēm relata a ocorrềncia de perdas de boro na forma de vapor durante a extração por meio da àgua. quente. REISENAUER et alii (1973) levantam um problema adicional com relação à utilização da água quente: relatam que muitos pesquisadores têm encontrado que o boro assim ex traído correlaciona-se bem com a absorção do elemento pelas plantas, mas não com respostas à aplicação de boro em cultü 
.18 .

ras conduzidas no campo; o que torna incompleta a proposição de COPE e ROUSE (1973) de que para o extrator ser adequado para dados de calibração a quantidade de nutriente extraída deve ser proporcional à absorvida pela cultura.

PONNAMPERUMA et alii(1981) re latam que o-HGI $9.0 .5 \mathrm{H}$ pode ser usado com sucesso para a extração do boro do solo disponivel às plantas. 0 s autores encontraram que os resulta dos obtidos atravēs déste método se reliacionam muito bem com os conseguidos pelo uso da água quente, $r^{\prime}=0,956^{* * *}$, sendo que a concentração de boro nas plantas de arroz foi melhor corrèlacionada com o método do $\mathrm{HCl} 0,05 \mathrm{M}, \mathrm{r}^{\prime} 0,96^{* *}$, do que com o método de BERGER e TRUOG (1939), $r^{\prime}=0,91^{* *}$.

Com relação à infiluência da textura na dis ponibilidade de boro OBUKHOV (1968) encontrou coeficiente de correlaçäo significativo entre o boro solüvel em àgua quente e o teor de argila $\left(r^{\prime}=0,60\right)$, por sua vez GUPTA (1968) observou que, na quase totalidade dos solos estudados, os teo res de boro solüvel em água foram menores em solos de textu ra grossa e maiores nos de textura fina. BRASIL SOBRINHO (1965), estudando o teor de boro em diversos solos do município de Piracicaba e outras regiões do estado de São Paulo, concluiu que os solos argilosos eram bem supridos, enquanto os areno sos se mostraram muito pobres no micronutriente. CASAGRANDE (1978), trabalhando com solos do município de. Piracicaba, encon 
.19.

trou correlação positiva e significativa entre o teor de ar gila e os valores de boro solúvel em àgua quente. HOROWITZ e DANTAS (1973) observaram uma tendência para o acūmulo de bo ro nos horizontes mais argilosos de solos representativos da zona litoral - mata de Pernambuco. 


\section{MATERIAL E METODOS}

\subsection{SOLOS}

Das sēries de solos do município de Piraci caba, mapeadas por RANZANI et alii (1966), foram escolhidas cinco: Luiz de Queiroz (Terra Roxa Estruturada, eutrófica), I racema (Latosol. Roxo, eutrófico), Sertãozinho(Latosol Verme Iho, textura arenosa, distrófico), Quebra Dente (Podzólico Vermelho Amarelo, textúra arenosa/mēdia) e Ribeirão Claro (Areia Quartzosa).

\subsection{AMOSTRAGEM E PREPARO DOS SOLOS}

As amostras foram coletadas a profundidade de 
0-30 cm, tomando-se aproximadamente $50 \mathrm{~kg}$ de terra de cada solo, os quais foram acondicionados em sacos plästicos, tra zidos à casa de vegetação, homogeneizados, secos ao ar e peneirados em tamis de näilon com malhas de $2 \mathrm{~mm}$ de abertu ra. De cada solo foi retirada uma amostra para as análises físicas e químicas.

\subsection{ANÄLISES QUIMICAS}

As anälises de pH, carbono, fösforo, potäs sio trocável, cálcio trocável, alumínio trocável e hidrogê. nio foram executadas de acordo com CATANI e JACINTHO (1974), os resultados (médias de duas repetições) encontram-se na Ta bela 1 .

\subsection{ANÄLISES FİSICAS}

As anālises granulométricas (Tabela 2) fo ram realizadas pelo método da pipeta, utilizando-se hexameta fosfato de södio a $5 \%$ como agente dispersante, de acordo com KILMER e ALEXANDER (1949).

Além das anālises granulométricas foram de terminados o poder de embebição, as densidades aparente e real, bem como foram calculados os espaços lacunares para ca da solo empregado no experimento (Tabela 3). 
Tabela 1. Resultados das anālises químicas dos solos estuda dos.

\begin{tabular}{|c|c|c|c|c|c|c|c|c|}
\hline \multirow[b]{2}{*}{ isolo } & \multirow[b]{2}{*}{$\begin{array}{c}\mathrm{pH} \\
\left(\mathrm{H}_{2} \mathrm{O}\right)\end{array}$} & \multicolumn{7}{|c|}{ miliequivalentes/100 g de TFSA } \\
\hline & & $\begin{array}{r}m .0 . \\
(\%)\end{array}$ & $\mathrm{PO}_{4}{ }^{(2)}$ & $\mathrm{K}^{+}$ & $\mathrm{Ca}^{2+}$ & $\mathrm{Mg}^{2+}$ & $\mathrm{Al}^{3+}$ & $\mathrm{H}^{+}$ \\
\hline Luiz de Quei roz (TRE) & 6,0 & $2,59^{\prime}$ & 0,06 & $0,2 \dot{6}$ & $5,2.3$ & 0,99 & 0,11 & 3,53 \\
\hline I racema (LR) & 6,1 & 2,43 & 0,90 & 0,40 & 5,62 & 1,73 & 0,10 & $3 ; 76$ \\
\hline Sertãozinho (LV) & 5,0 & 0,78 & 0,23 & 0,23 & 1,52 & 0,02 & 0,62 & 3,72 \\
\hline Quebra Dente (P\A) & 5,8 & 0,98 & 0,08 & 0,12 & 2,99 & 0,33 & 0,11 & 2,13 \\
\hline Ribei rão Claro ( $A Q)$ & 5,5 & $i, 1$ & 0,04 & 0,06 & 2,46 & 0,66 & 0,15 & 2,60 \\
\hline
\end{tabular}

(1) $\%$ M.0. $=\dot{C} \% \times 1,724$.

(2) solüvel em $\dot{\mathrm{H}}_{2} \mathrm{SO}_{4} 0,05 \mathrm{~N}$. 


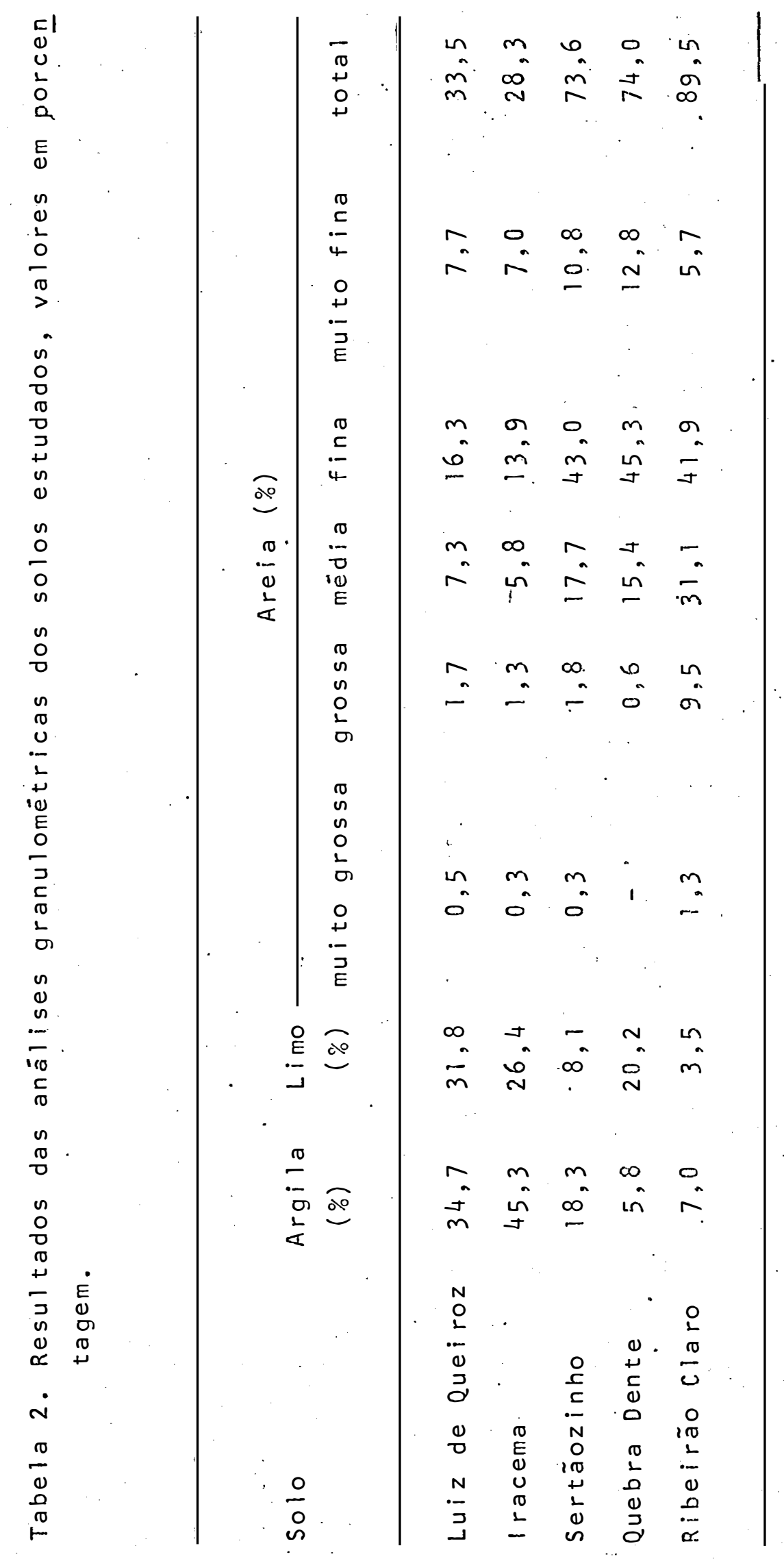


.24 .

Tabela 3. Poder de embebição, densidade aparente (da), dens $\mathbf{i}$ dade real (dr) e espaços lacunares dos solos estü dados (1):

\begin{tabular}{lcccc}
\hline Solo & $\begin{array}{c}\text { Poder de } \\
\text { embeb ição } \\
(\%)\end{array}$ & $\begin{array}{c}\text { Densidade } \\
\text { aparente } \\
\left(\mathrm{g} / \mathrm{cm}^{3}\right)\end{array}$ & $\begin{array}{c}\text { Densidade } \\
\text { real } \\
\left(\mathrm{g} / \mathrm{cm}^{3}\right)\end{array}$ & $\begin{array}{c}\text { Espaços lacunares } \\
\left(\mathrm{E} .1 .=\frac{\mathrm{dr}-\mathrm{da}}{\mathrm{dr}} \cdot 100\right)\end{array}$ \\
\hline Luiz de Quei roż & 37,88 & 1,100 & 2,500 & 56,00 \\
I racema & 42,50 & 1,000 & 2,247 & 55,50 \\
Sertãozinho & 28,97 & 1,200 & 2,439 & 50,80 \\
Quebra Dente & 24,78 & 1,280 & 2,222 & 42,39 \\
Ribei rão Claro & 28,69 & 1,340 & 2,666 & 49,74 \\
\hline
\end{tabular}

(1) Determinações realizadás no laboratōrio de fertilidade do solo do Departamento de Solos, Geologia e Fertilizan tes da ESALQ. 
3.5. DETERMINAÇĀO QUIIMICA DO BORO NO SOLO

\subsubsection{BORO SOLŪVEL EM ÁGUA QUENTE (GUPTA, 1967) \\ 3.5.1.1. EXTRAÇĀO}

Tomou-se $20 \mathrm{~g}$ de solo seco ao ar e peneirado em tamis de 100 "mesh", colocou-se em becker de vidro (Py rex n: 1000) de $250 \mathrm{ml}$ de capacidade, adicionou-se $40 \mathrm{ml}$ de àgua destilada, pesou-se, agitou-se o conteüdo do becker com um bastão de náilon, cobriu-se com vidro relögio e colocouse num prato quente. Apōs a fervura começar deixou-se o mate rial sobre o prato quente por 5 minutos, sendo que quando houve a formação de espuma intensa-uma leve remoção do vidro relögio por 1 ou 2 segundos foi suficiente para desfazer a mesma. Após a fervura esperou-se o esfriamento dos beckers que foram pesados compensando-se a perda de peso com àgua destilada, filtrouse em papel de filtro Whatman 42 receben do-se o extrato em frascos plästicos. Neste ponto, como a guns extratos fossem turvos, realizou-se uma ligeira modifi cação no mëtodo de GUPTA (1967), ou seja, tomou-se $20 \mathrm{ml}$ do filtrado, adicionou-se $5 \mathrm{ml}$ de $\mathrm{HCl} 6 \mathrm{~N}^{*}$ e filtrou-se em papel de filtro Whatman 42 obtendo-se filtrados claros. Os extra tos, contidos em frascos plästicos, foram guardados em refri gerador para posterior determinação. Cada sërie de extrações foi acompanhada de duas provas em branco. 


\subsubsection{DETERMINAÇĀO}

Tomou-se $2 \mathrm{ml}$ do extrato, colocou-se em copo plästico que foi deixado em estufa a $80^{\circ} \mathrm{C}$ durante 4 horas ocorrendo a.secagem do extrato com a consequente volatiliza ção do àcido clorídrico. A seguir o resíduo foi retomado com 1. ml de ägua destilada e o conteüdo de boro determinado pelo método da curcumina (DIBLE et alii, 1954), utilizando-sé cur va padrão obtida atravēs dos padrões 0,$0 ; 0,10 ; 0,20 ; 0,30$; 0,40 e $0,50 \mathrm{ppm}$ de boro.

\subsubsection{BORO SOLÜVEL EM HCL: 0,05 M (PONNAMPERUMA et alii, 1981). \\ 3.5.2.1. EXTRAÇĀO}

Tomou-se $10 \mathrm{~g}$ de solo séco ao ar e peneirado em tamis de 100 "me'sh", colocou-se em erlenmeyer de plästí co (Nalgene) de $125 \mathrm{ml}$ de capacidade, adicionou-se $20 \mathrm{ml}$ de HCl $0,05 \mathrm{M}$ e agitou-se.por 5 minutos num agitador horizontal a $180 \pm 10$ ciclos/minuto. Em seguida filtrou-se em papel de filtro Whatman 42 , sendo que os extratos, contidos em fras cos plästicos, foram guardados em refrigerador para poste rior determinação. Conio prova em branco foram utilizados 20 $\mathrm{ml}$ de $\mathrm{HCl} 0,05 \cdot \mathrm{M}$ agitados também por 5 minutós. 


\subsubsection{DETERMINACĀO}

Foi empregado o método da curcumina (DIBLE et alii, 1954), utilizando-se para o cálculo do teor de boro das amostras a curva padrão obtida com os padrões 0,$00 ; 0,05$; 0,$10 ; 0,15 ; 0,20 ; 0,25 ; 0,30 ; 0,35$ e 0,40 ppm de boro.

3.5.3. BORO SOLÜVEL EM ACETATO DE AMÔNIO 1,0 N, PH 4.8 (GUPTA E STEWART, 1975)

\subsubsection{EXTRAÇĀO}

Tomou-se $10 \mathrm{~g}$ de solo seco ao ar e peneirado em tamis de 100 "mesh", colocou-se em erlenmeyer de plásti co (Nalgene) de $125^{\circ} \mathrm{ml}$ de capacidade, adicionou-se $1,0 \mathrm{~g}$ de carvão vegetal previamente lavado com a solução extratora, $50 \mathrm{ml}$ da solução de acetato de amônio $1,0 \mathrm{~N}, \mathrm{pH} 4,8$ e agi tou-se por 30 minutos num agitador horizontal a $180 \pm 10 \mathrm{ci}$ clos/minuto. Em seguida filtrou-se em papel de filtro Whatman 42, sendo que os extratos, contidos em frascos plásticos, fo ram guardados em refrigerador para posterior determinação. Como prova ém branco foi utilizado $1 \mathrm{~g}$ de carvão vegetal que recebeu $50 \mathrm{ml}$ da solução extratora, tendo também sido agitą do por 30 minutos. 


\subsubsection{DETERMINAÇAO}

Foi empregado o mëtodo da azometina-H segundo o procedimento descrito por GUPTA e STEWART (1975), cuja úni ca modificação foi a necessidade do uso de padrões bem mais diluídos que os usados pelos autores, ou seja, utilizaram-se os padrões 0,$00 ; 0,04 ; 0,06$ e $0,08 \mathrm{ppm}$ de boro. A azometina foi sintetizada de acordo com MAZAHERI (1976).

\subsection{ANÁLISE DO MATERIAL VEGETAL.}

$$
\text { Os extratos para a. determinação de P, K, Ca, }
$$

$\mathrm{Mg}, \mathrm{S}, \mathrm{B}, \mathrm{Cu}, \mathrm{Zn}, \mathrm{Mn}$ e $\mathrm{Fe}$ foram obtidos por méio de digestão nitrico-perclörica segundo a metodologia proposta por SARRU GE e HAG (1974), sendo os elementos determinados pelos se guintes métodos:

P. Ca, Mg, B, Cu, Zn, Mn e Fe..., Plasma Atom Model 975 - Es pectrômetro de plasma indu zido em argônio. .

K.......................... Perkin Elmer 306 - Espectro fotometria de emissão em di luição por fluxo contínuo.

s.................... Turbidimetria em fluxo con tinuo (KRUG et alii, 1977). 
os extratos para a determinação do nitrogênio foram preparados utilizando digestão sulfürica (SARRUGE e HAAG, 1974), sendo a determinação realizada pelo mëtodo do semimicro Kjeldahl.

\subsection{MONTAGEM E EXECUÇĀO DO EXPERIMENTO}

\section{3,7.1, DEL INEAMENTO EXPERIMENTAL}

0 experimento foi instalado sob um esquema fa torial, num delineamento inteiramente casualizado com 4 re petições. Foram utilizados 5 solos e 7 doses de boro, sendo que os vasos eram mudados. semanalmente de posição de acordo com sorteios.

\subsubsection{CORRECĀO DA ACIDEZ DOS SOLOS}

A necessidade de calagem foi determinada de acórdo com o método de CATANl e GALLO (1955), o qual fornece a quantidade de calcário necessāria para elevar o pH a 6,5. Procedeu-se à mistura de $30 \mathrm{~kg}$ de cada solo com as respecti vas quantidades de $\mathrm{CaCO}_{3} P . \dot{A}$., a seguir foi realizada a incu bação durante trinta dias em vasos. de barro revestidos inter namente com neutrol, sendo que a umidade era ireposta por meio de àgua destilada em dias alternados. Apōs a incubação os solos foram secos ao ar, destorroados e novamente peneira 
dos em tamis de $2 \mathrm{~mm}$ de diâmetro.

\subsubsection{RECIPIENTES}

os recipientes utilizados foram latas de óleo lubrificante com capacidade de $1000 \mathrm{ml}$, que foram cortadas de modo a se obter um volume final de aproximadamente $600 \mathrm{ml}$. As la tas foram cuidadosamente limpas, pintadas internamente com neutrol e externamente com tinta aluminio. Cada vaso recebeu $.500 \mathrm{ml}$ dos solos em estudo

\subsubsection{FORNECIMENTO DE NUTRIENTES}

Com exceção do boro todos os vasos receberam a mesma quantidade dé nutrientes (Tabela 4), sendo que todos os produtos utilizados possuiam qualidade anälítica (P.A.).

0 boro foi fórnecido nas doses de 0,$0 ; 0,1$; 0,$2 ; 0,3 ; 0,4 ; 0,5$ e. $1,1 \mathrm{pom}$, de maneira parcelada para se evitar efeito fitotóxico. A solução contendo boro foi preparada pela dissolução de 0,5716 g. de àcido bórico em ägua destilada com o volume final tendo sido completado a um li tro, a seguir esta solução foi di luída vinte vezes obtendose uma solução de trabalho com concentração de $0,005 \mathrm{mg}$ de boro por mililitro, que, foi aplicada nos diferentes tratamen tos conforme a Tabela 5 . 
Tabela 4. Quantidade de nutrientes fornecida por vaso e pro duto químico utilizado.

\begin{tabular}{|c|c|c|c|c|}
\hline \multirow{2}{*}{ Elemento } & \multicolumn{3}{|c|}{ Dose (ppm) } & \multirow{2}{*}{ Fonte } \\
\hline & Semeadura & & ertura & \\
\hline N & 100 & & 100 & $\mathrm{NH}_{4} \mathrm{NO}_{3}$ \\
\hline $\mathrm{P}$ & 200 & $i$ & - & $\mathrm{Ca}\left(\mathrm{H}_{2} \mathrm{PO}_{4}\right)_{2} \cdot \mathrm{H}_{2} \mathrm{O}$ \\
\hline K & 75 & & 75 & $\mathrm{~K}_{2} \mathrm{SO}_{4}$ \\
\hline $\mathrm{Ca}(1)$ & 129 & & - & $\ldots$ \\
\hline $\mathrm{Mg}$ & 15 & & - & $\mathrm{MgSO}_{4} \cdot 7 \mathrm{H}_{2} \mathrm{O}$ \\
\hline$s^{(1)}$ & 59 & & 31 & - \\
\hline $\mathrm{Cu}$ & 1,5 & & - & $\mathrm{CuSO}_{4} \cdot 5 \mathrm{H}_{2} \mathrm{O}$ \\
\hline $\mathrm{Fe}$ & 5,0 & & - & Fe-EDTA \\
\hline$M n$ & 3,0 & & - & $\mathrm{MnSO}_{4} \cdot \mathrm{H}_{2} \mathrm{O}$ \\
\hline $\mathrm{Zn}$ & 5,0 & & - & $\mathrm{ZnSO}_{4} \cdot \mathrm{H}_{2} \mathrm{O}$ \\
\hline Mo & 1,0 & & - & $\mathrm{Na}_{2} \mathrm{Mo}_{4} \cdot 2 \mathrm{H}_{2} \mathrm{O}$ \\
\hline
\end{tabular}

(1) No preparo das soluções não houve preocupação com os teo res de Ca e S, o cälcio fornecido pela mesma fonte de $\bar{P}$ e o enxofre pelas fontes de K, Mg, Cu, Fe, Mn e Zn. 


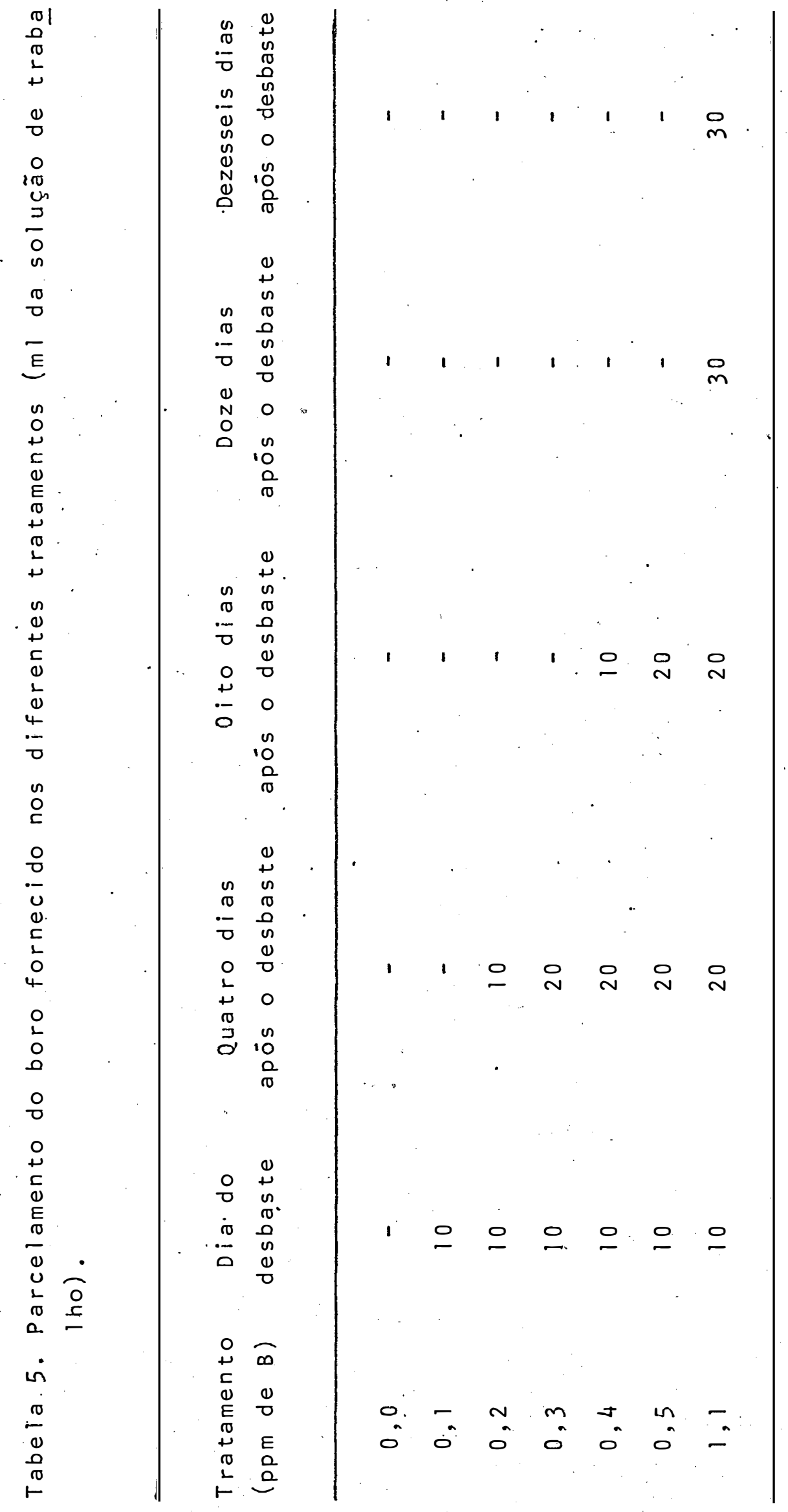

.32. 
3.7.5. VARIEDADE DE GIRASSOL UTILIZADA

Empregou-se a variedade Anhandy, proveniente do Instituto Agronômico de Campinas.

\section{7,6. TËCNICA EXPERIMENTAL}

0s vasos receberam $550,5.00,600,640$ e 670 gramas de terra fina seca ao ar, respectivamente dos, solos Luiz de Queiroz, Iracema, Sertãozinho, Quebra Dente e. Ribe rão Claro; os pesos variáveis de solo foram utilizados para se obter um volume de $500 \mathrm{ml}$ de tẹra fina seca ao ar em to dos os recipientes. Em seguida os vasos receberam os nutrien tes conforme a Tabela 4, procedeu-se ao revolvimento da ter ra contida em cada vaso visando-se uma boa distribuição dos nutrientes. Vinte e quatro horas antes da semeadura os vasos receberam água ạtē ser atingido o peso correspondente a $75 \%$ do poder de embebição. A semeadura foi realizada através do enterrio parcial de doże sementes por vaso.

A umidade dos vasos foi mantida a $75 \%$ do poder de embebição, sendo que no início do ensaio apenas uma irrigação diāria, acompanhada da pesagem dos vasos era sufi ciente. Após o desbaste houve a necessidade de duas irriga ções diārias e na metade final do experimento três irriga 
ções diárias, sempre acompanhadas da pesagem no final da ta de de todos o vasos.

Cinco dias após a semeadura foi realizado um desbaste parcial, reduzindo-se para sete o nümero de plantas por vaso; passados mais cinco dias foi executado o desbaste final, tendo restado cinco plantas por vaso. A adubação em cobertura com nitrogênio e potássio foi realizada quinze dias apōs a semeadura.

Diariamente foi anotado o nümero de plantas de cada vaso que mostravam os sintomas de deficiencia de bo ro, sendo anotados os dias em que a clorose bem definida na base das folhas terminais apareceu em cada planta; as folhas velhas que iriam cair foram coletadas a cada dois dias e guar dadas em sacos de papel. Por oćasião da colheita, realizada 44 dias após a semeadura, após a medida individual da altura de cada planta a partir do colo, as cinco plantas de cada va so foram colhidas conjuntamente e separadas em caules, folhas do terço superior da planta (no presente trabalho chamadas de folhas novas) e folhas restantes (no presente trabalho cha madas de folhas velhas). Após a secagem dos solos foram reti radas as raízes; todo material vegetal foi seco em estufa a $60-65^{\circ} \mathrm{C}$ até peso constante, apös o que se procedeu à pesagem e o preparo das digestões nítrico-perclörica. e sulfúrica. Os solos foram peneirados em tamis de 100 "mesh" e acondicio- 
.35 .

nados em sacos plásticos para posterior deteirminação do boro disponivel pelos três extratores em estudo. 


\section{RESULTADOS E DISCUSSAO}

\subsection{SINTOMAS VISUAIS}

0 primeiro solo a mostrar plantas com sinto mas de deficiência de boro foi o Quebrä Dente, no qual 23 dias apōs a semeadura jā existia no tratamento.0,0 ppm de B uma planta deficiente, serido que passados mais cinco dias to das as plantas do tratamento que não recebeu boro neste so 10, nas quatro repetições, mostraram os sintomas de deficiên cia deste micronutriente: 0 solo Sertãozinho foi visualmente o segundo mais deficiente seguido, em ordem decrescente, pe los solos Ribeirão Claro, Luiz de Queiroz e Iracema.

0s sintomas observados nas plantas deficien tes em boro apareceram na seguinte sequéncia: inicialmente 
surgiu uma leve clorose na base das folhas terminais, que pro grediu para clorose bem definida acompanhada de necrose e en curvamento para baixo das mesmas folhas. Num estádio mais avançado houve a morte da gema terminal com a consequente pa ralização do crescimento da planta; além do aparecimento de consistência coriácea nas folhas terminais. A sintomatoló gia da deficiência de boro foi, em geral, bastante semelhan te à observada por BRASIL SOBRINHO (1965) e CASAGRANDE (1978), tendo sido observada a consistência coriăcea não re latada por estes autores mas descrita por BLAMEY et, alii (1979) para girassóis crescendo em condições de campo.

\subsection{CRESCIMENTO}

Por ocasião da colheita do ensaióforam ob servados: altura média das plantas/vaso, peso da matéria se ca da parte aérea/vaso, peso da matéria seca das raízes/vaso e peso total da matéria seca/vaso (Tabelas 6,7 e 8 ).

Houve efeito das doses de boro sobre as qua tro medidas de crescimento estudadas, as quais, com exceção do peso da matêria seca das raízes que foi significativo ape nas a $5 \%$ de probabilidade, tiveram valores de $F$ significati vos ao nível de $1 \%$ de probabilidade (Tabela 6).

$$
\text { A altura das plantas, com exceção do solo }
$$

Luiz de Queiroz, apresentou maiores valores do teste $F$ que 


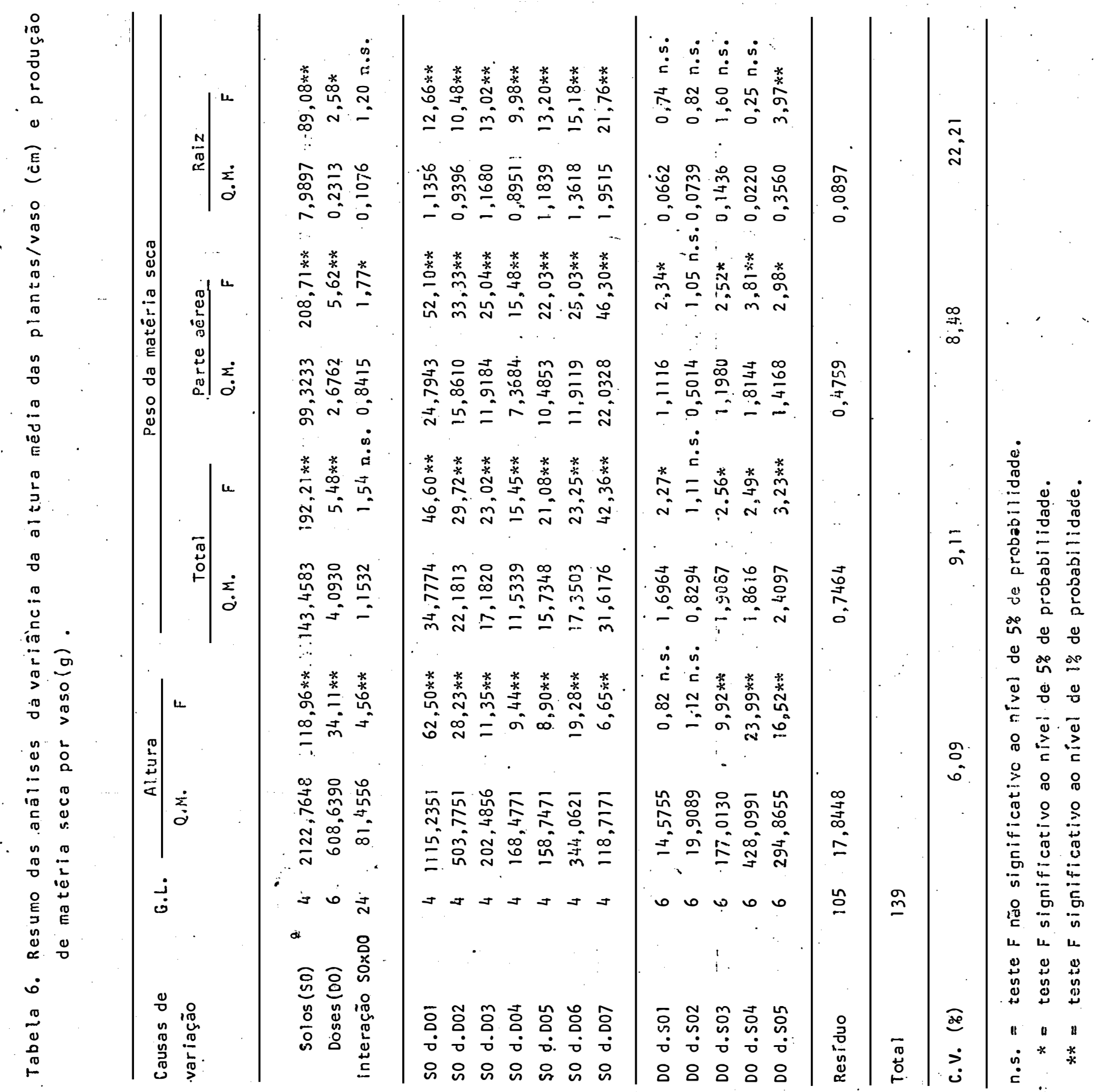




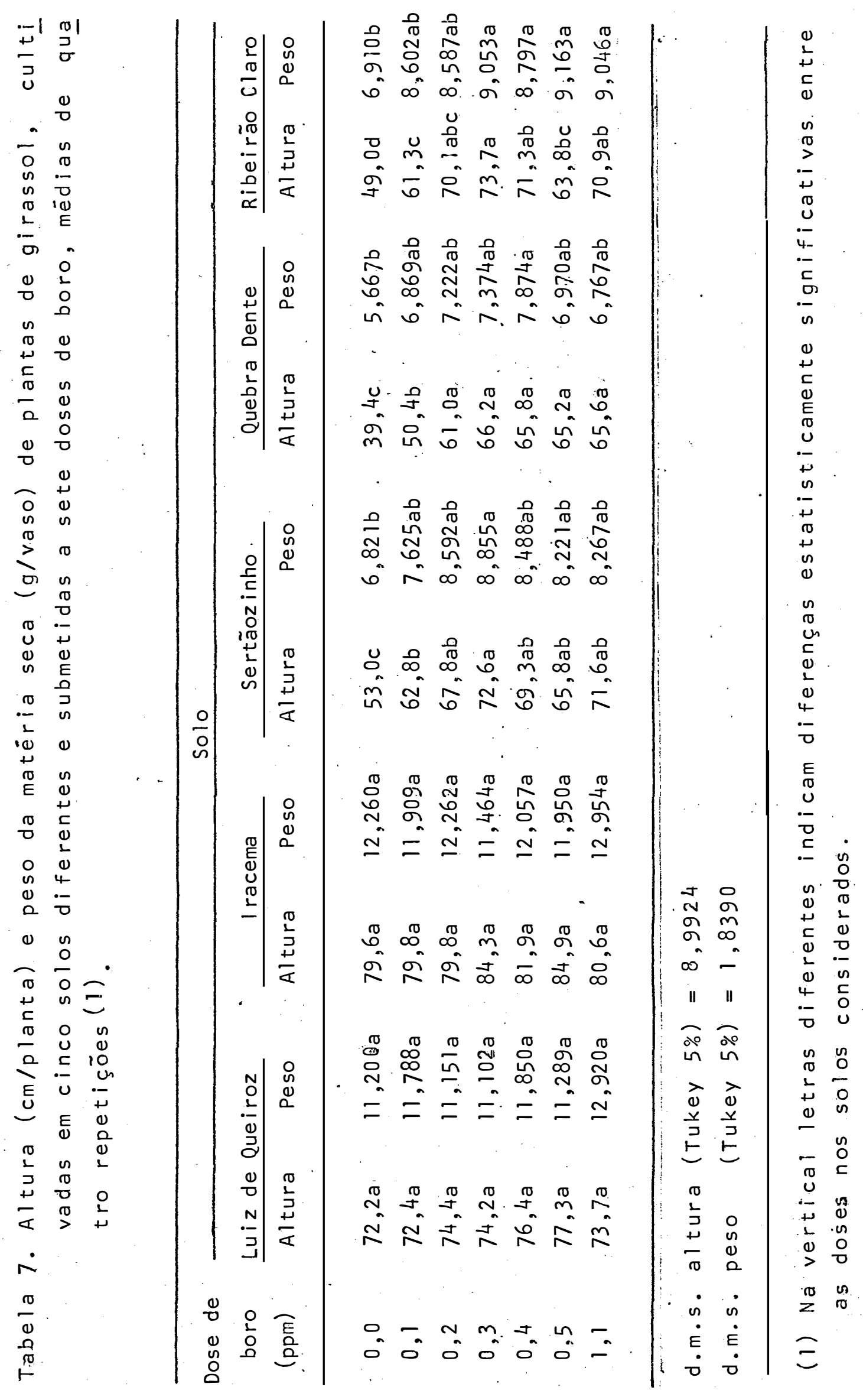




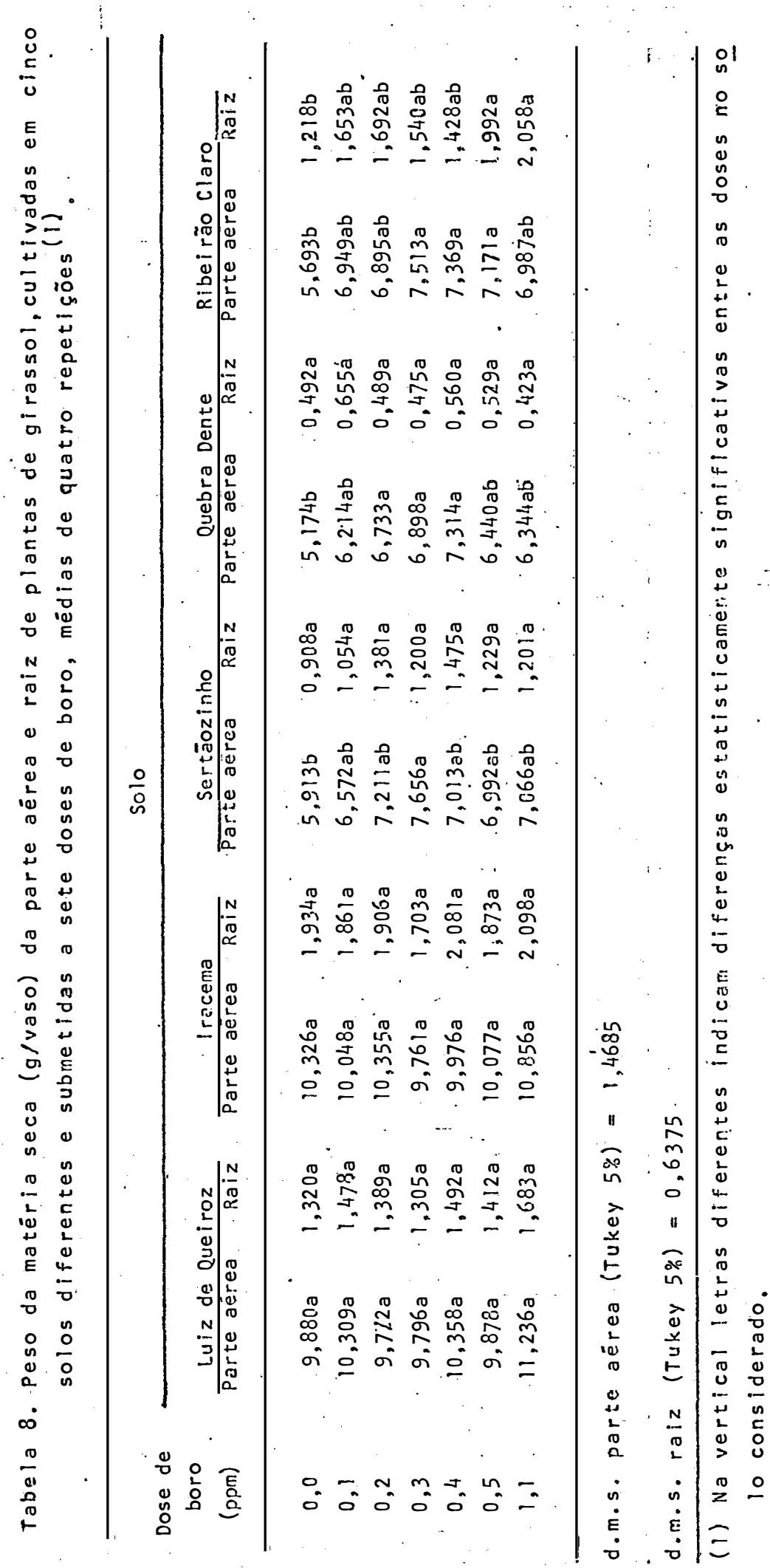

.40 . 
as medidas de crescimento baseadas em peso de matéria seca, podendo-se concluir que a altura das plantas refletiu melhor o estado nutricional que as medidas em peso, o que estä de acordo com o obtido por CASAGRANDE (1978). o peso da matéria seca da parte aérea e de toda a planta praticamente se equi valeram para avaliar o estado nutricional, "fato este que não ocorreu com o peso da matéría seca das raízes que apontou efeito de doses de boro apenas no solo Ribeirão Claro, não sendo, portanto, ủm bom parấmetro para a avaliação do estado nutricional em relação ao boro.

Os dados médios de alturas e pesos da matēria seca (Tabélas 7 e 8) mostram que para os solos. Luiz de Que roz e I racema não houve efeito estátisticamente significati vo das doses de boro sobre as quatro medidas de crescimento estudadas. Para os solos Sertãozinho, Quebra Dente e Ribe rao Claro houve efeito significativo das doses sobre a altu ra, peso da matéria seca da parte aérea e total, sendo que a altura das plantas confirmou ser uma medida da disponibilida de de boro maís sensível que as demais. 0 peso da matéria se ca das raizes somente refletiu o efeito das doses de boro no solo Ribeirão Claro, confirmando ser.dentro as quatro medi das de crescimento estudadas a que pior reflete o estado nu tricional em relação ao boro.

C̣om. relação à altura das plantas para os cin co solos estudados os tratamentos com doses de boro acima 
de $0,2 \mathrm{ppm}$ näo apresentaram valores estatisticamente superio res à altura alcançada por este ültimo, levando à conclusão, tendo a altura das plantas como parámetro de crescimento, que 0,2 ppm de boro foram suficientes para o desenvolvimento nor mal do girassol nas condições empregadas; com relação ao pe so da matéria seca total e das partes das plantas 0,1 ppm de boro foram suficientes para o desenvolvimento normal das plantas de girassol: Estes valores estão de acordo com o ob tido por CASAGRANDE (1978), cujo solo mais deficiente em bo ro foi.tambëm o Quebra Dente, no aspecto de que a altura da planta é uma medida mais sensível que o peso da matéria seca em relaçãọ à disponibilidade de boro, no entanto, as doses de boro necessárias para o desenvolvimento normál das plan tas obtidas por CASAGRANDE (1978) foram mais elevadas, fato este, provavelmente, devido ao período de duração do ensaio, que foi de 54 dias, ao passo que no presente trabalho a co Theita foi realizada quando as plantas atingiram 44 dias de ịdade.

\subsection{COMPOSIÇĀO MINERAL DAS PLANTAS}

\subsubsection{TEORES}

As Tabelas 9 a 28 apresentam os resultados dos teores de nitrogênio, fósforo, potássio, cälcio, magnésio, en xofre, zinco, cobre, ferro e manganês nas quatro partes estu 


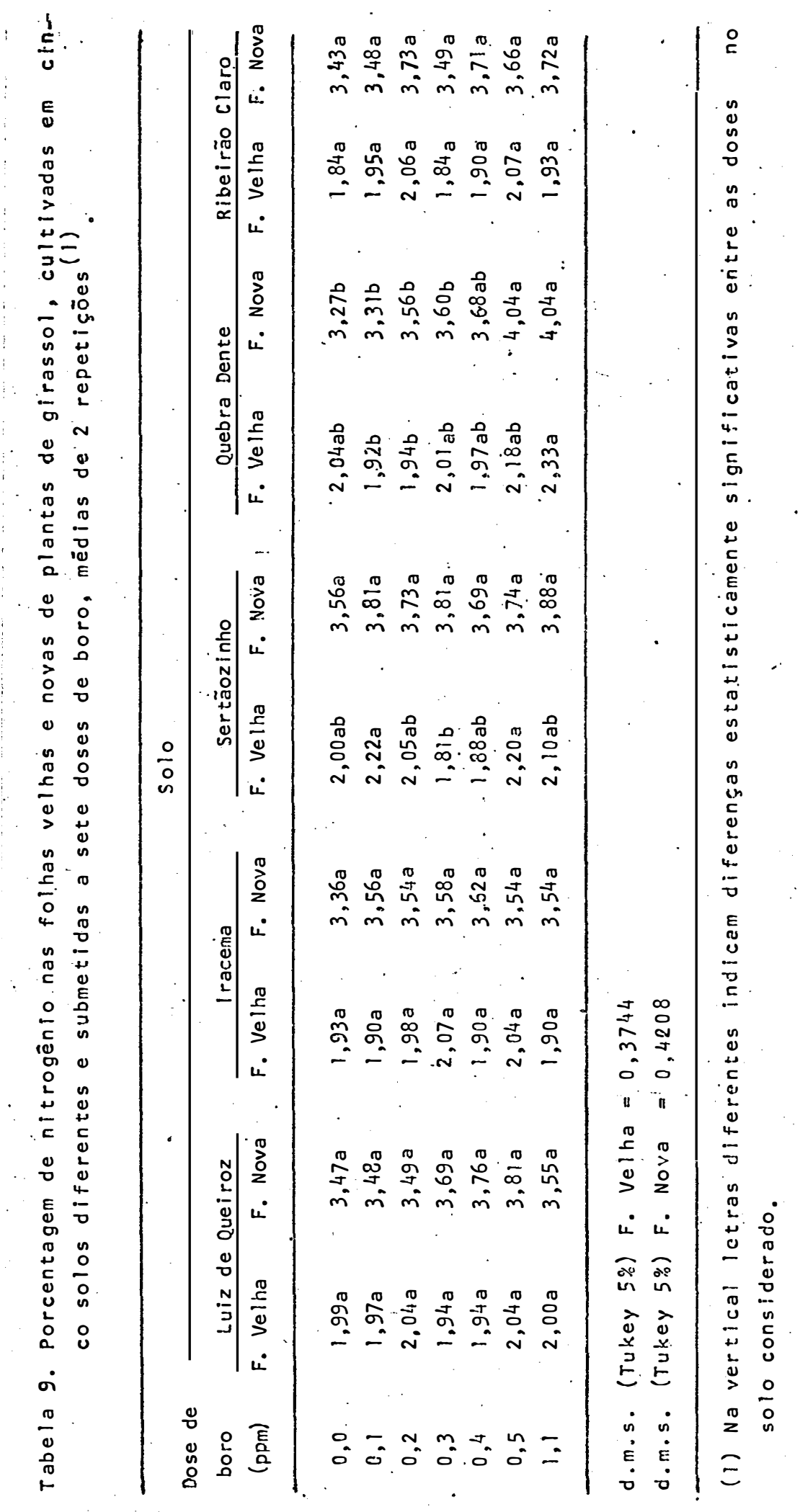




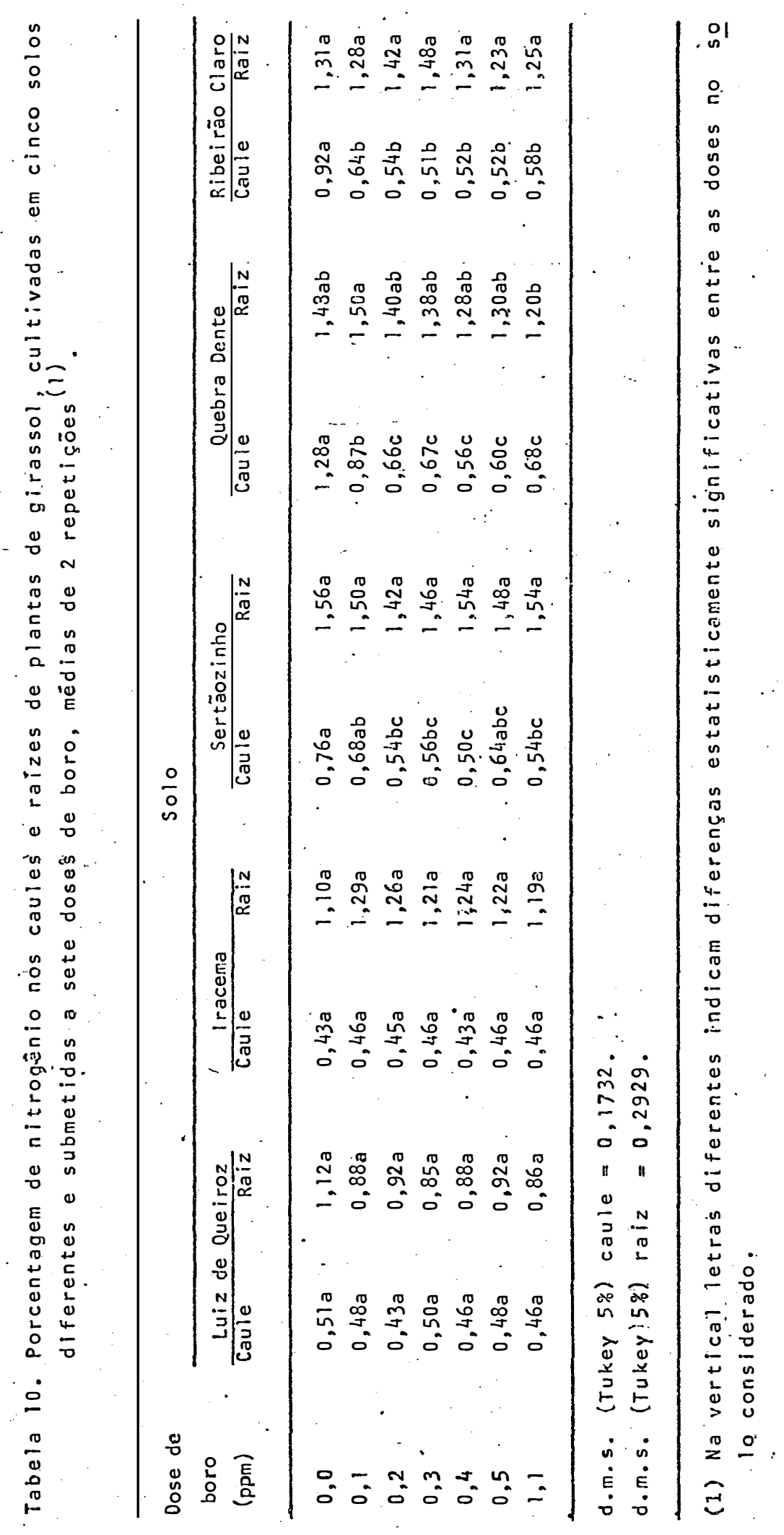




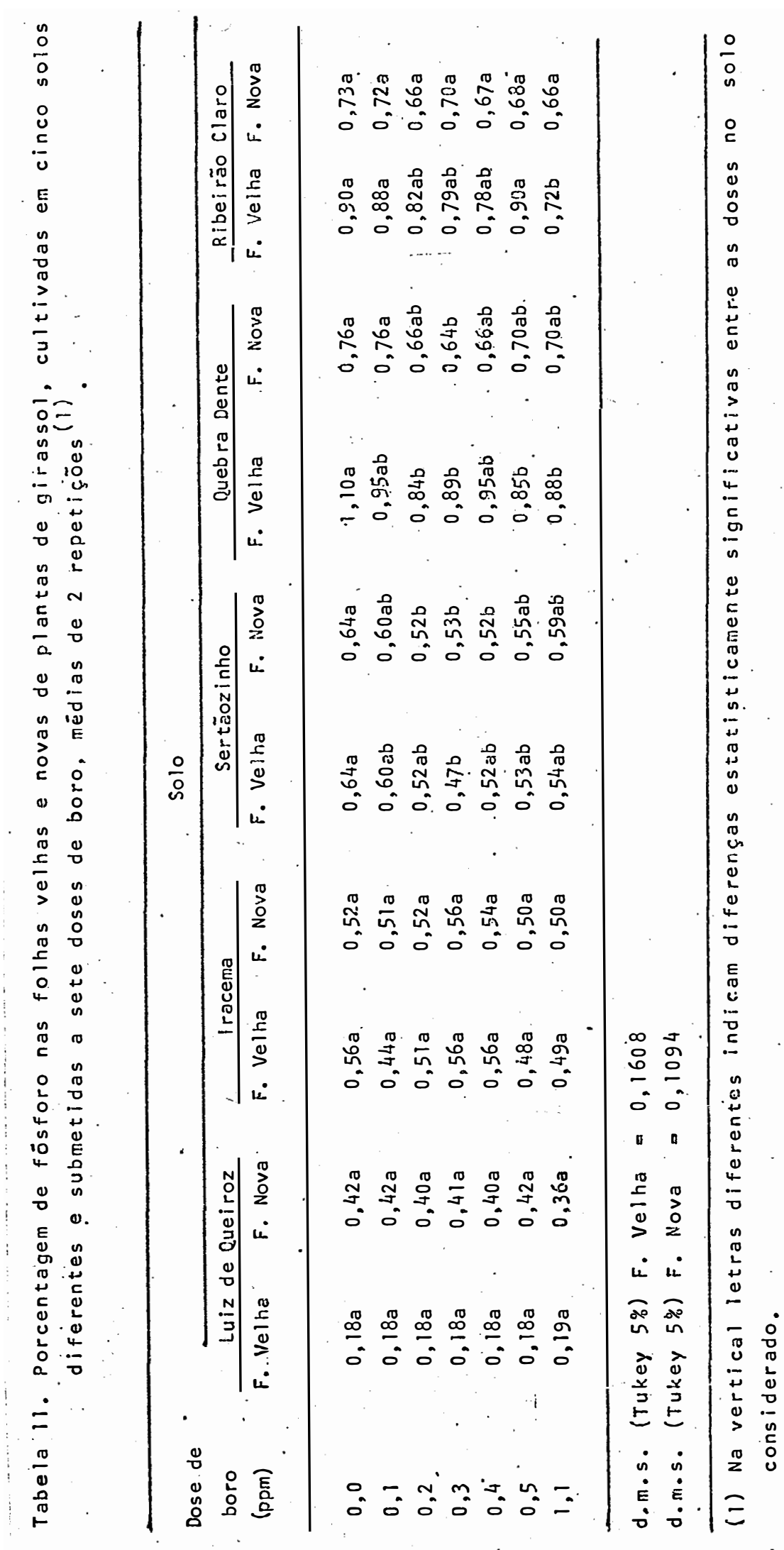




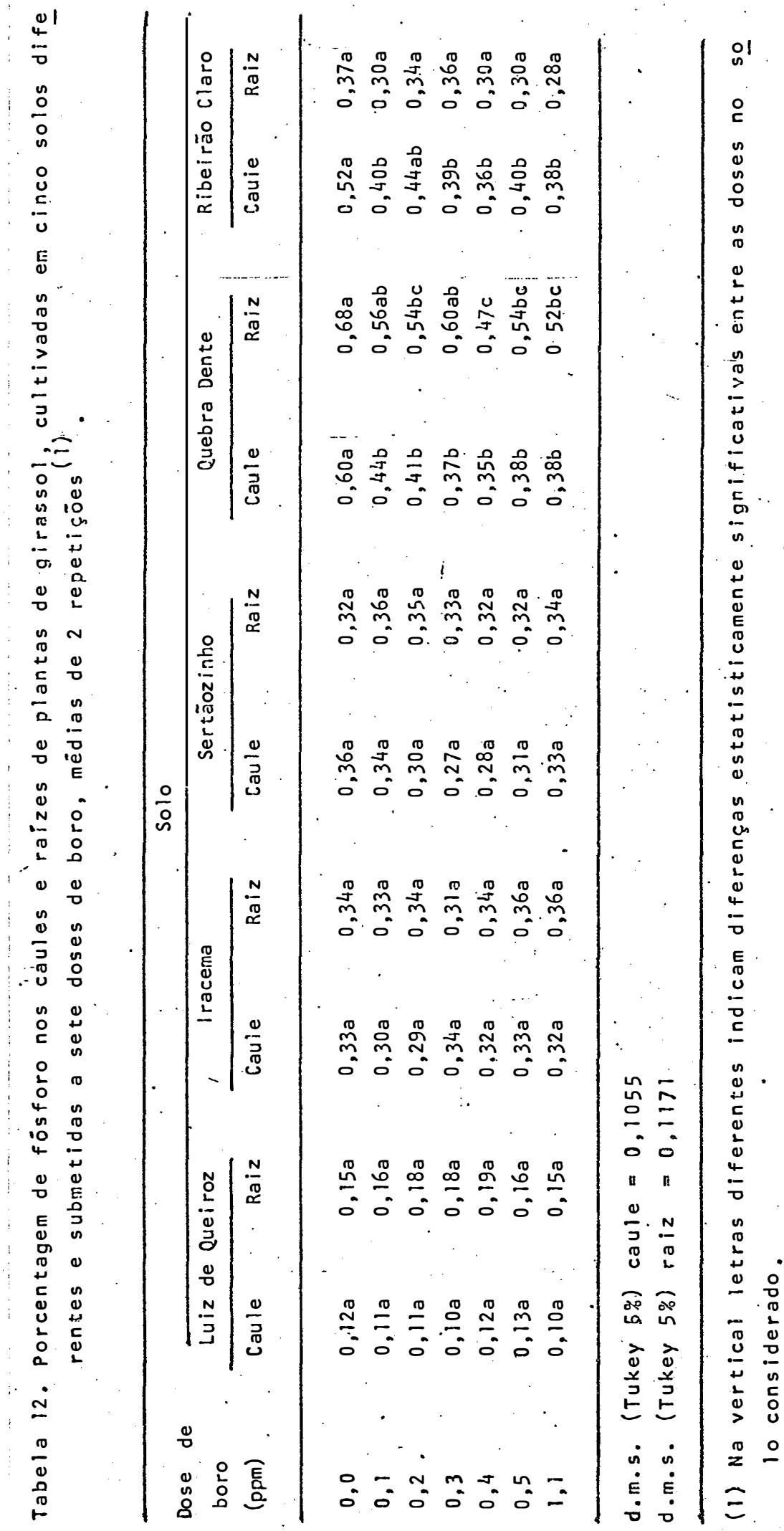

.46. 


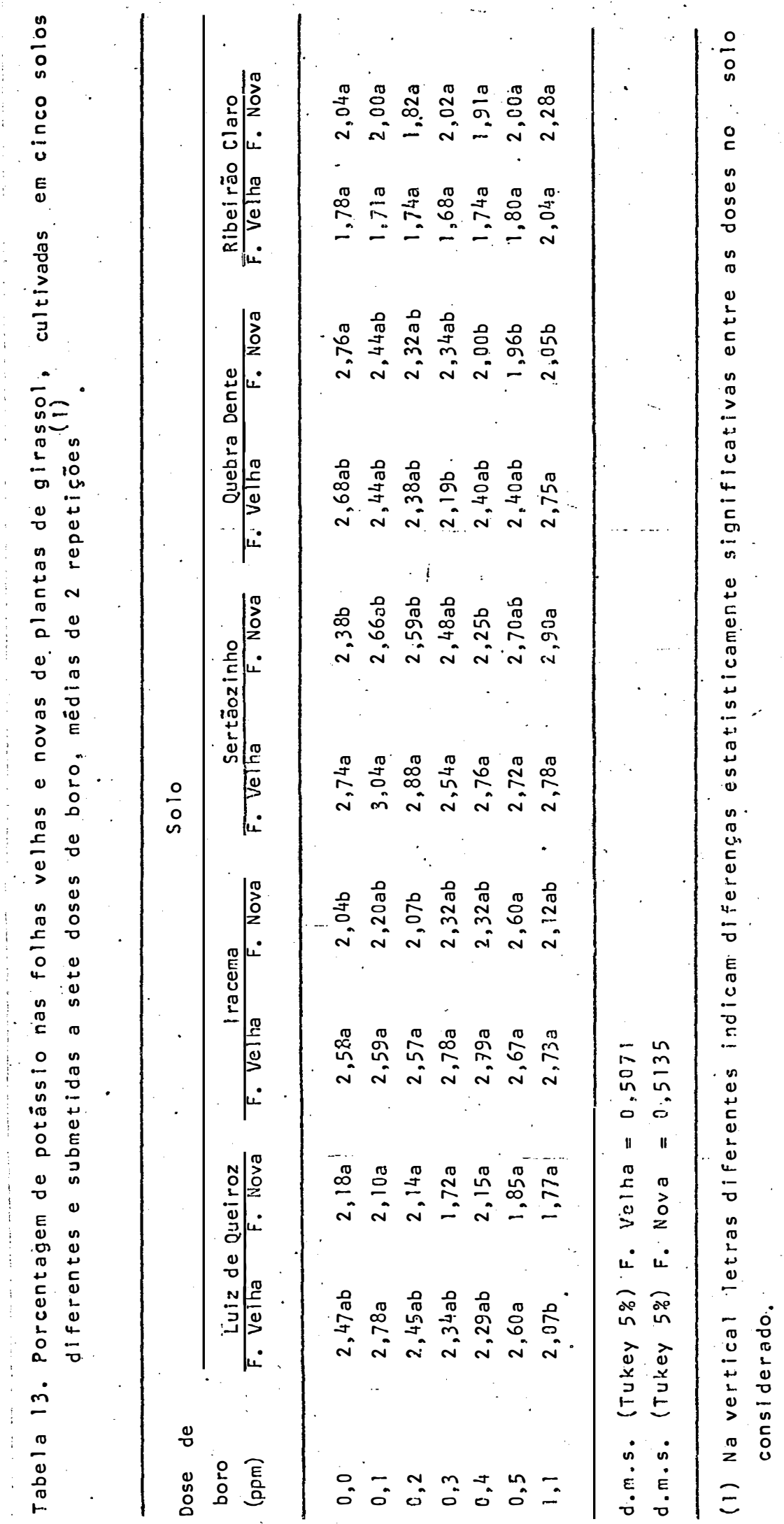




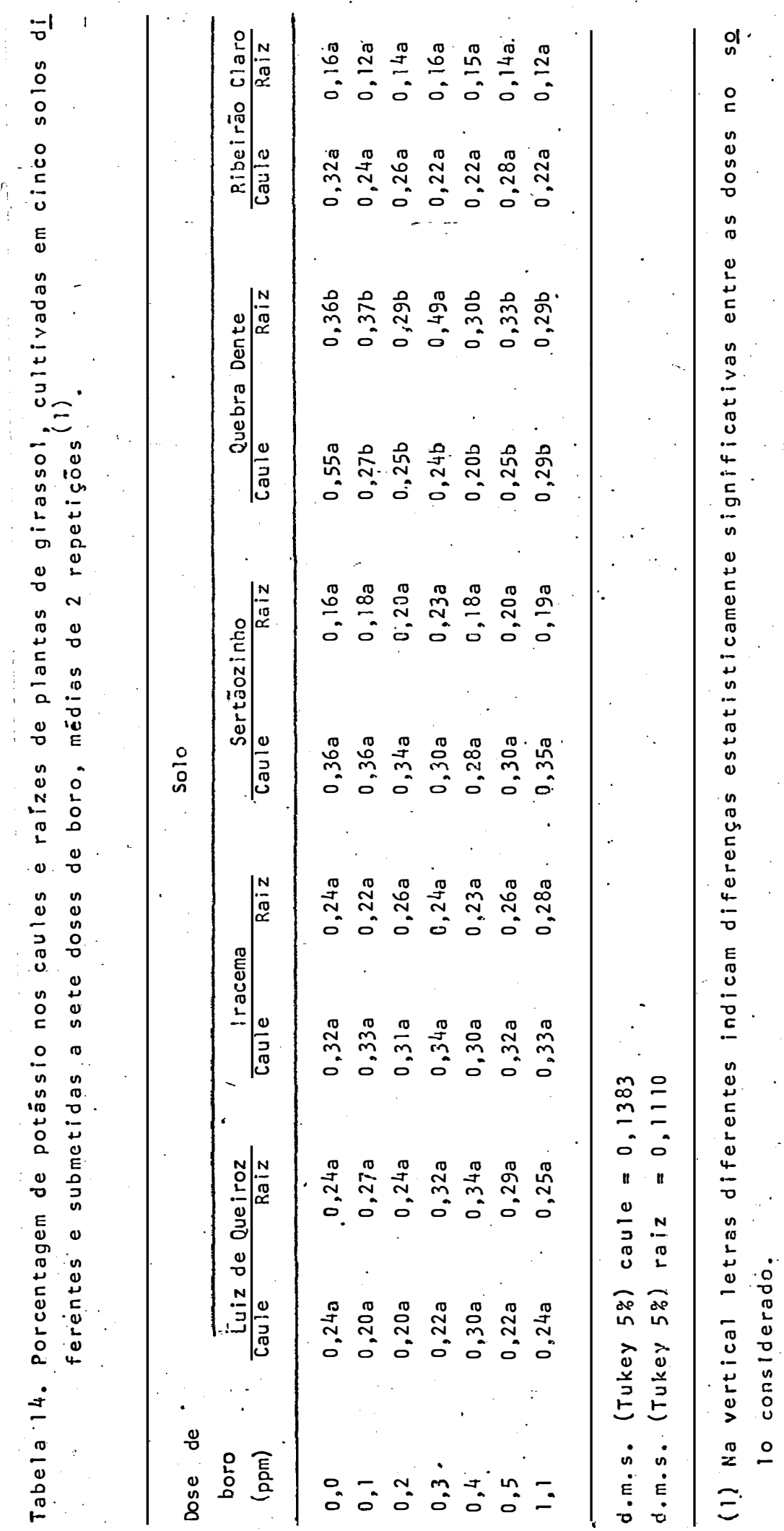




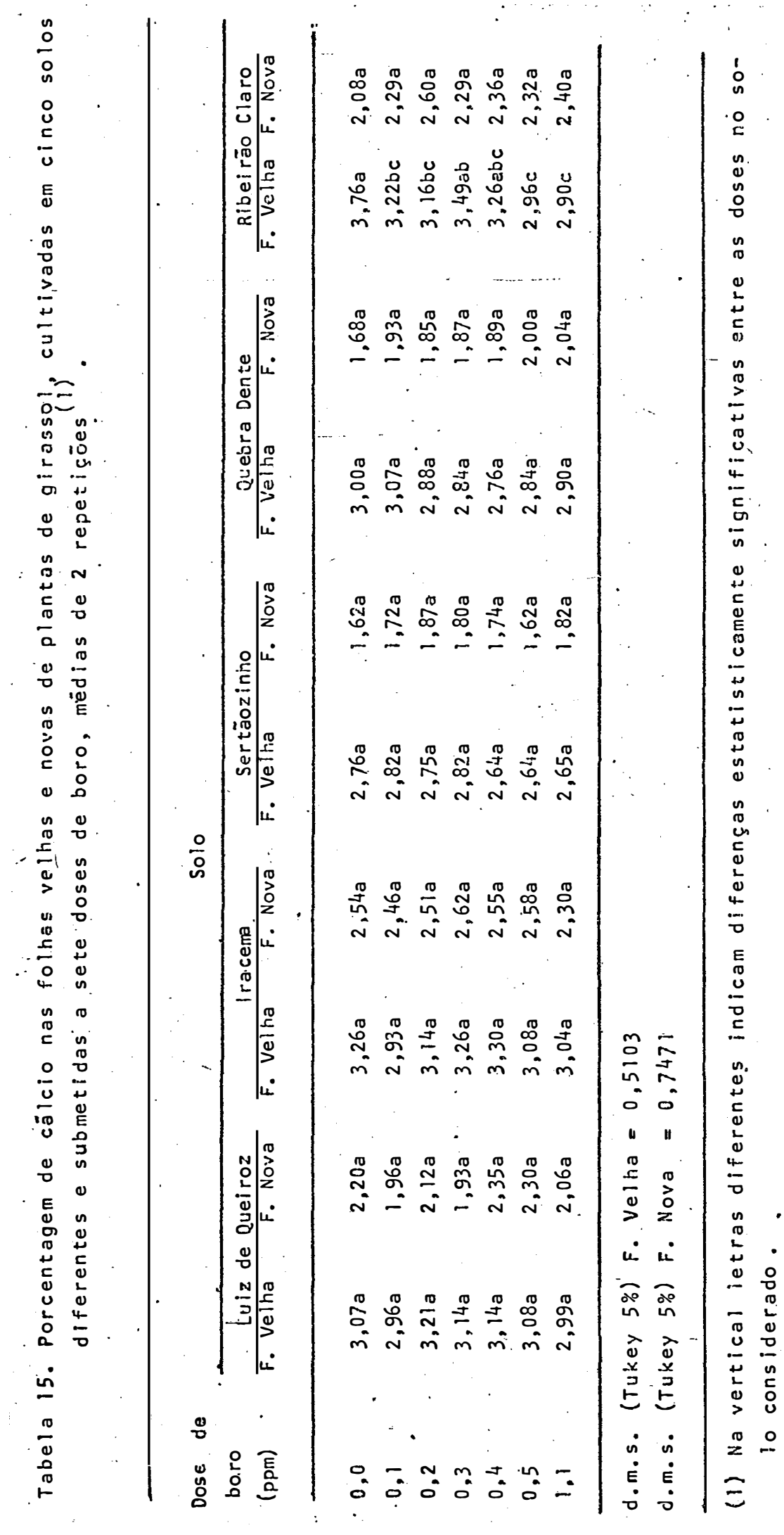

.49. 


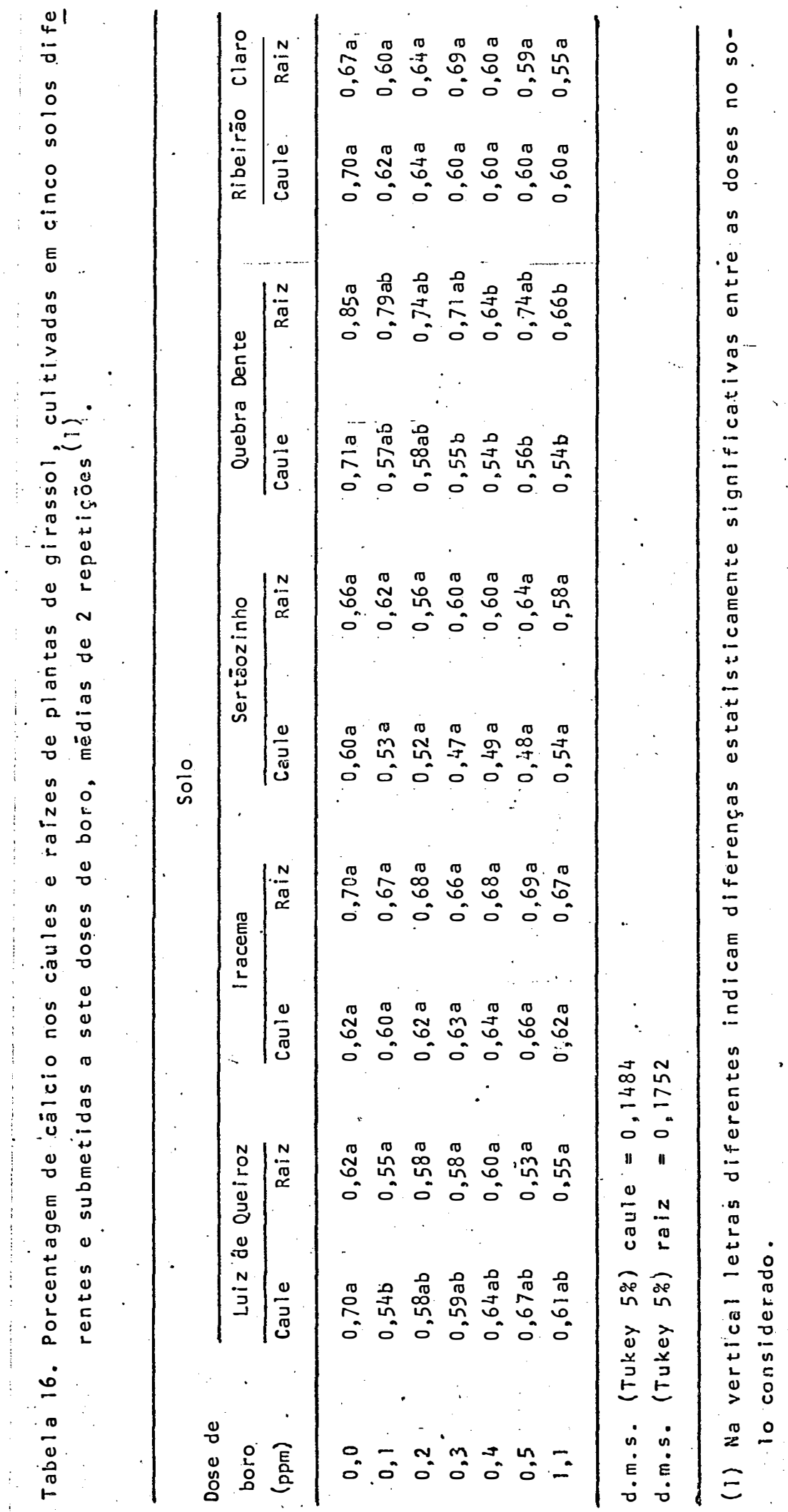




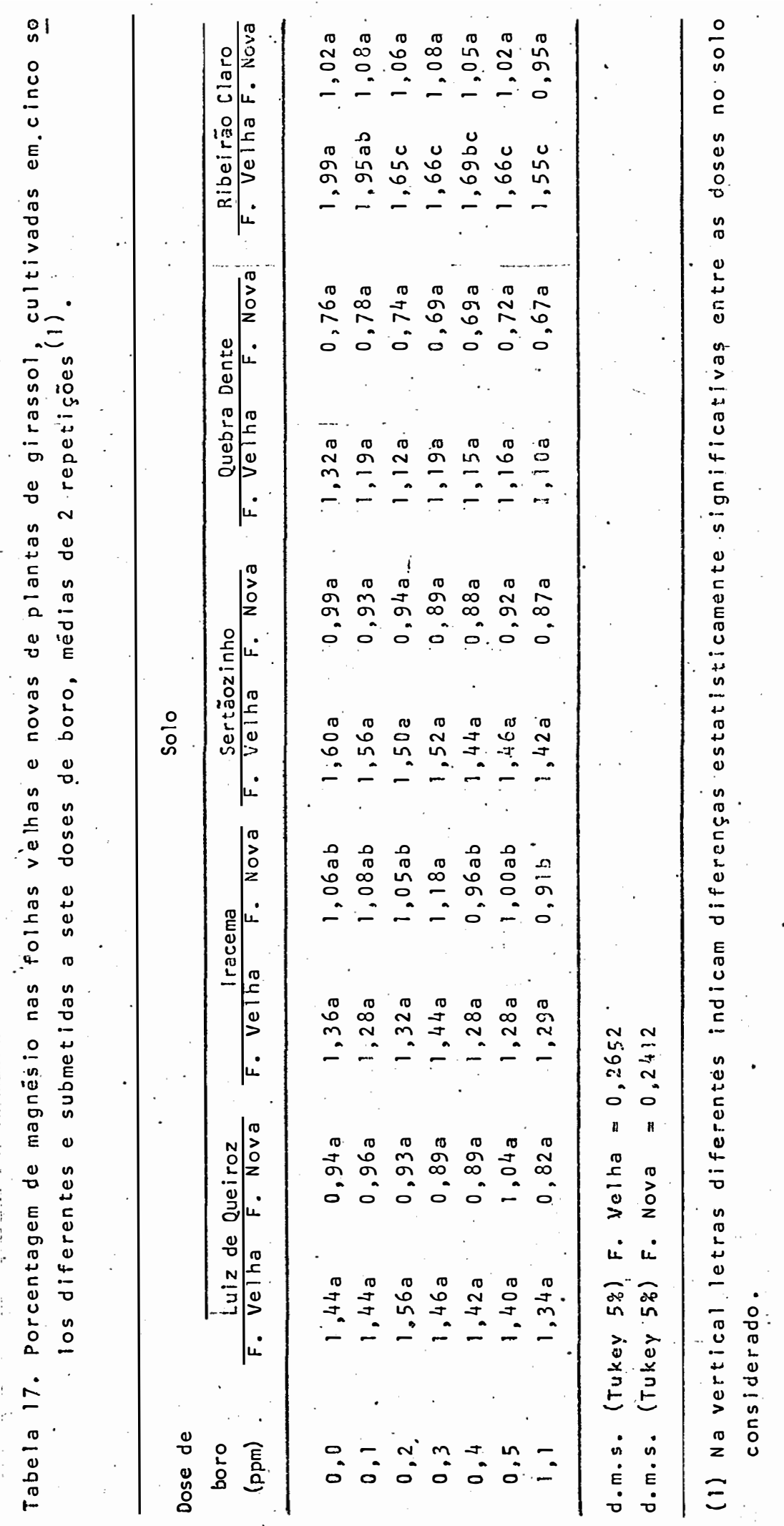




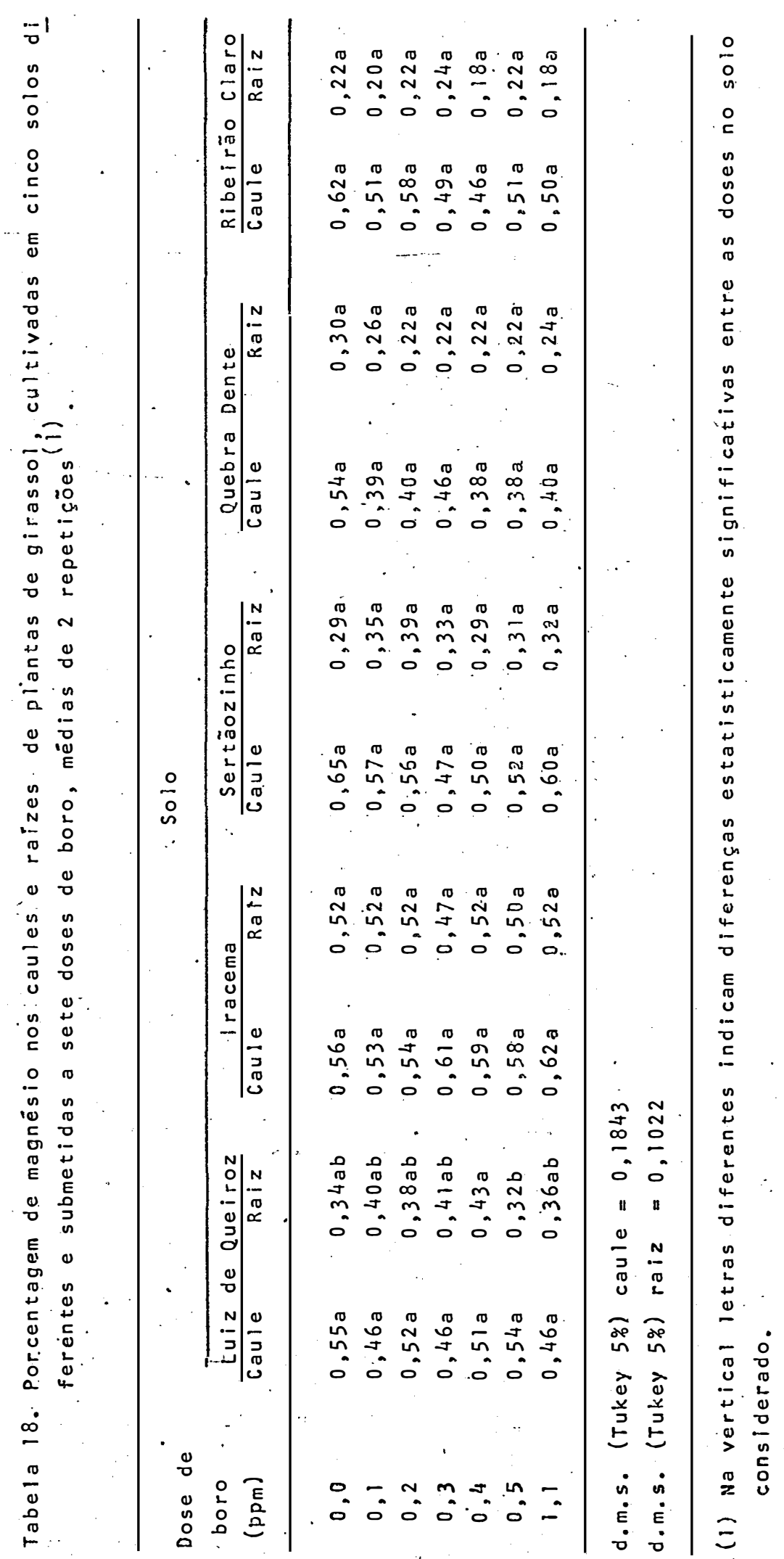

.52 . 
.53.

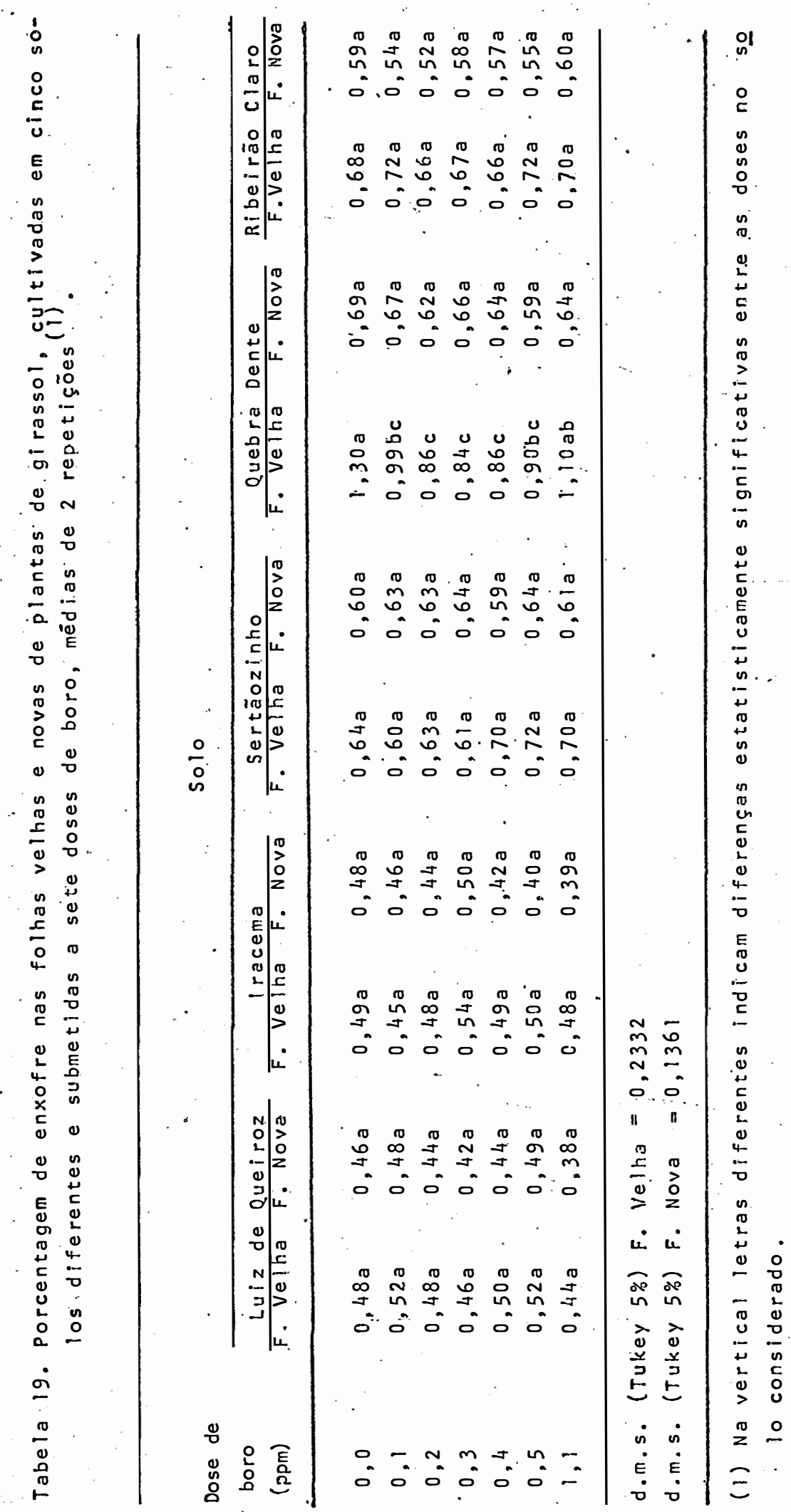


.54 .

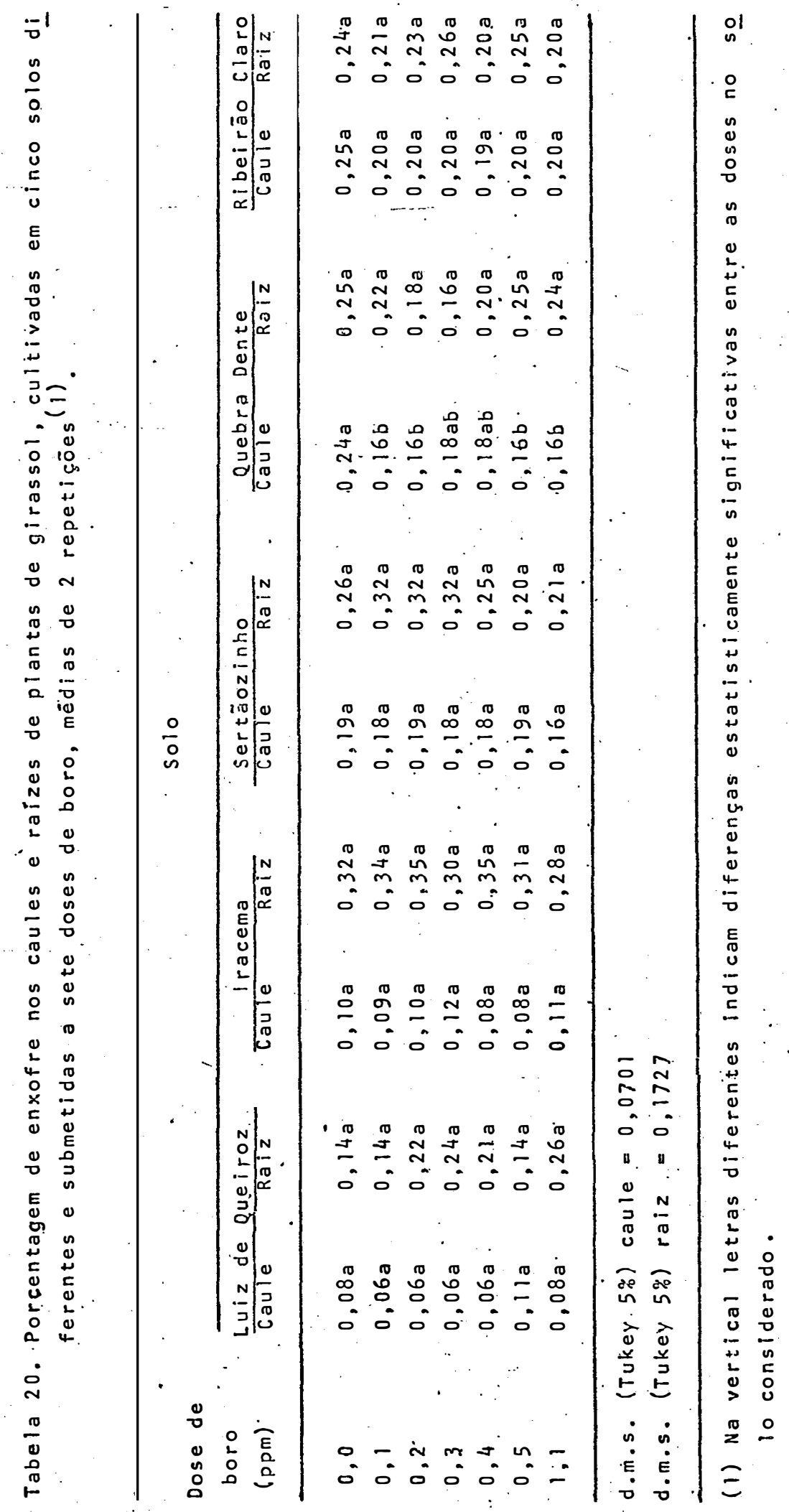




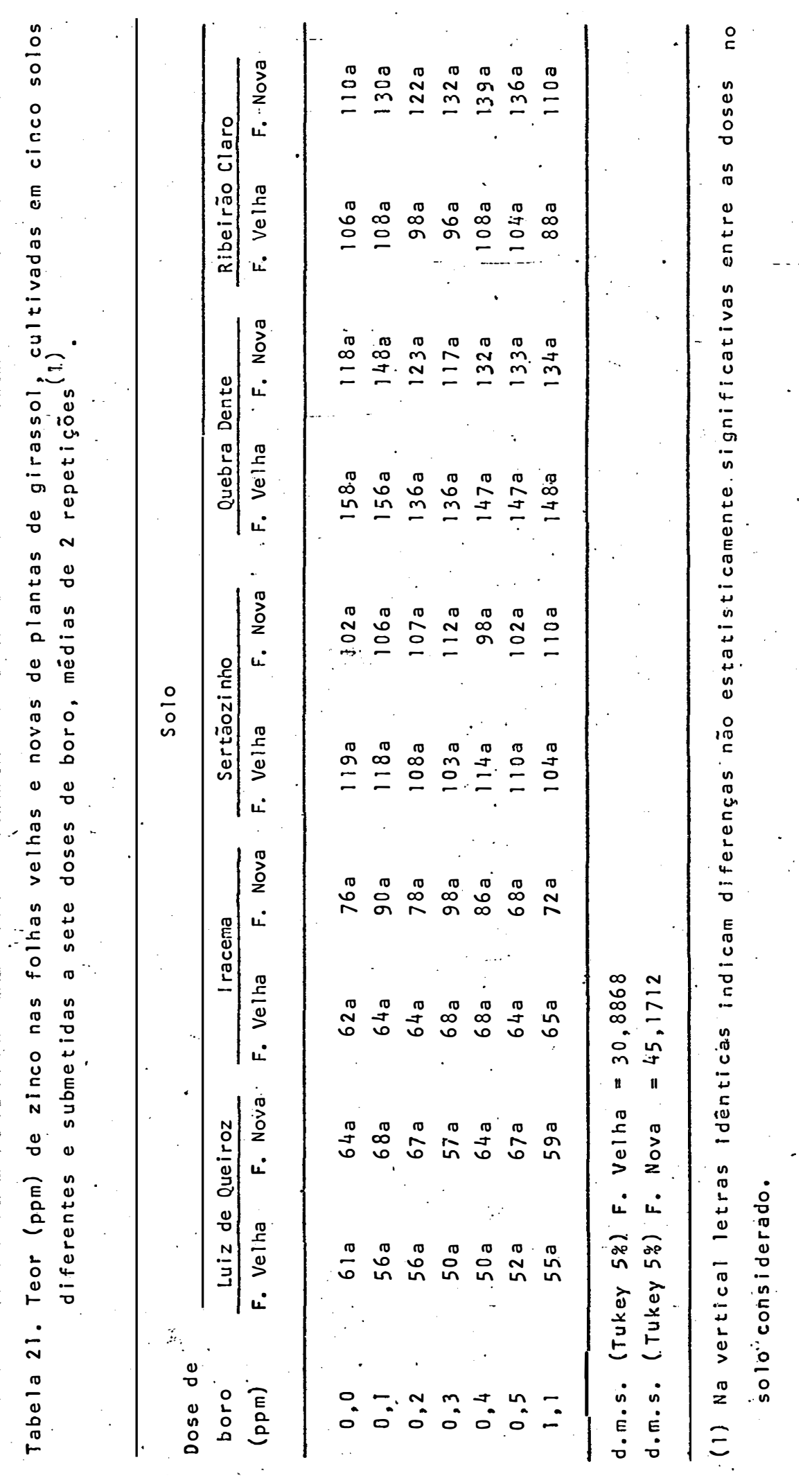




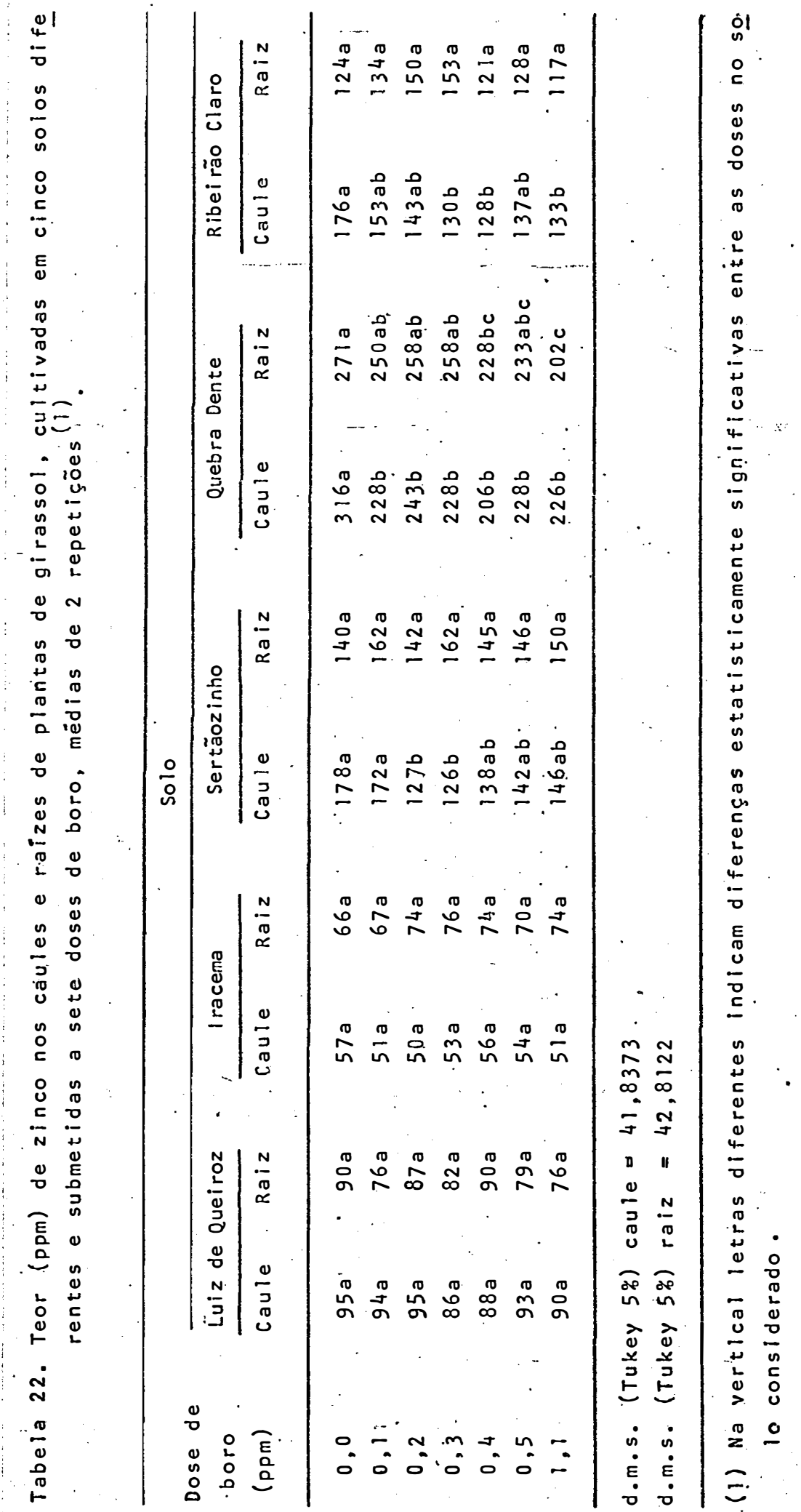




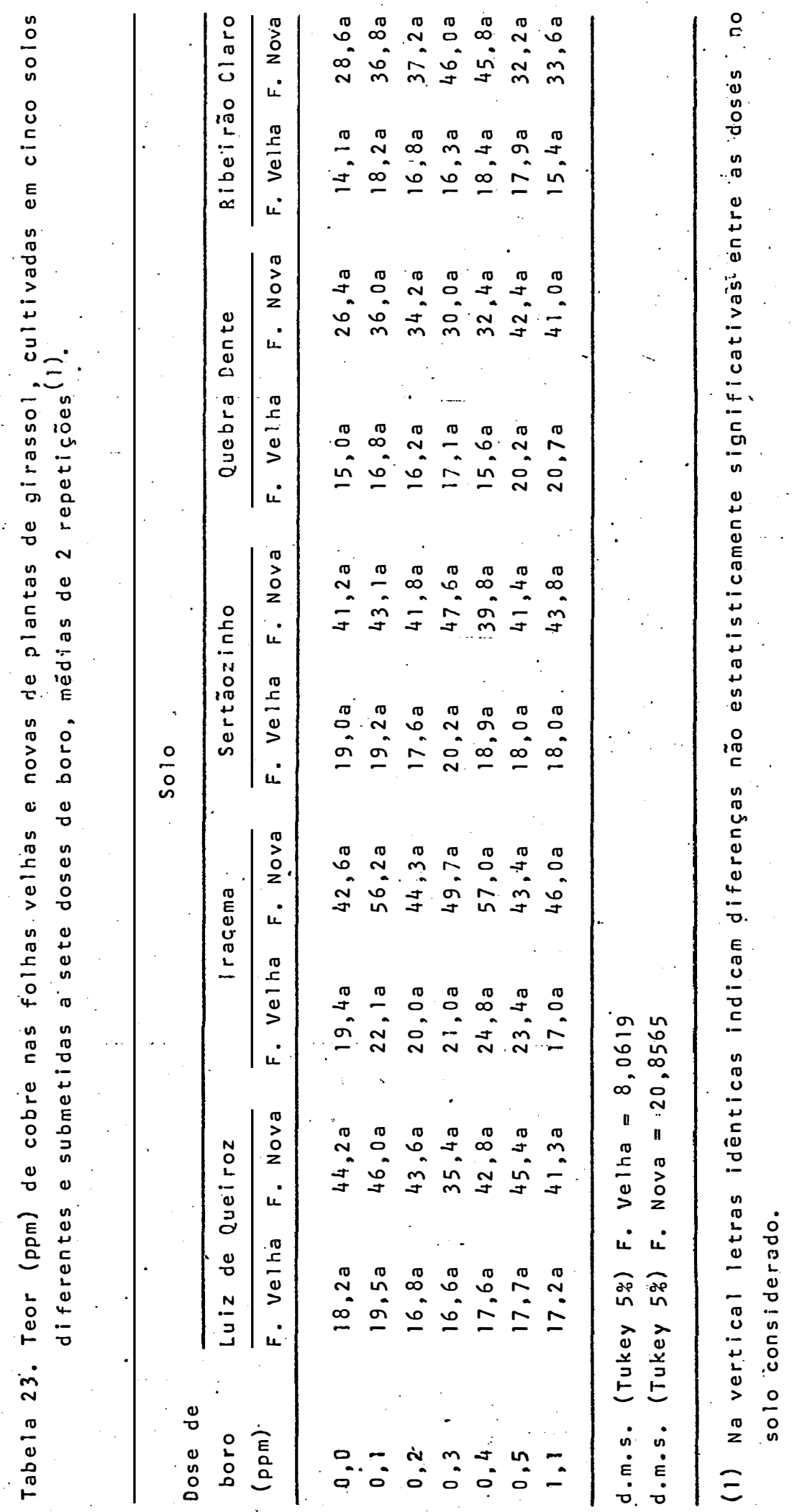




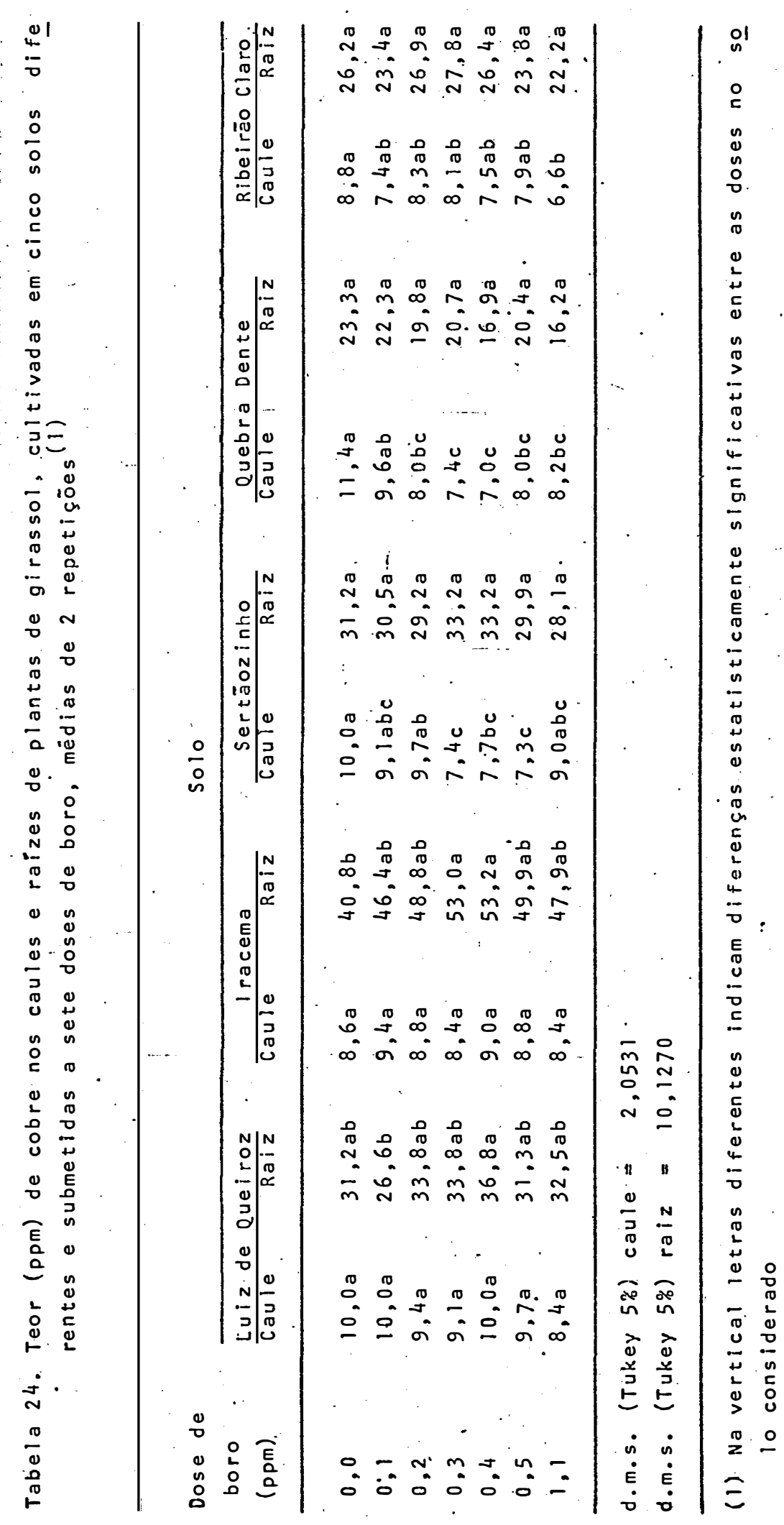




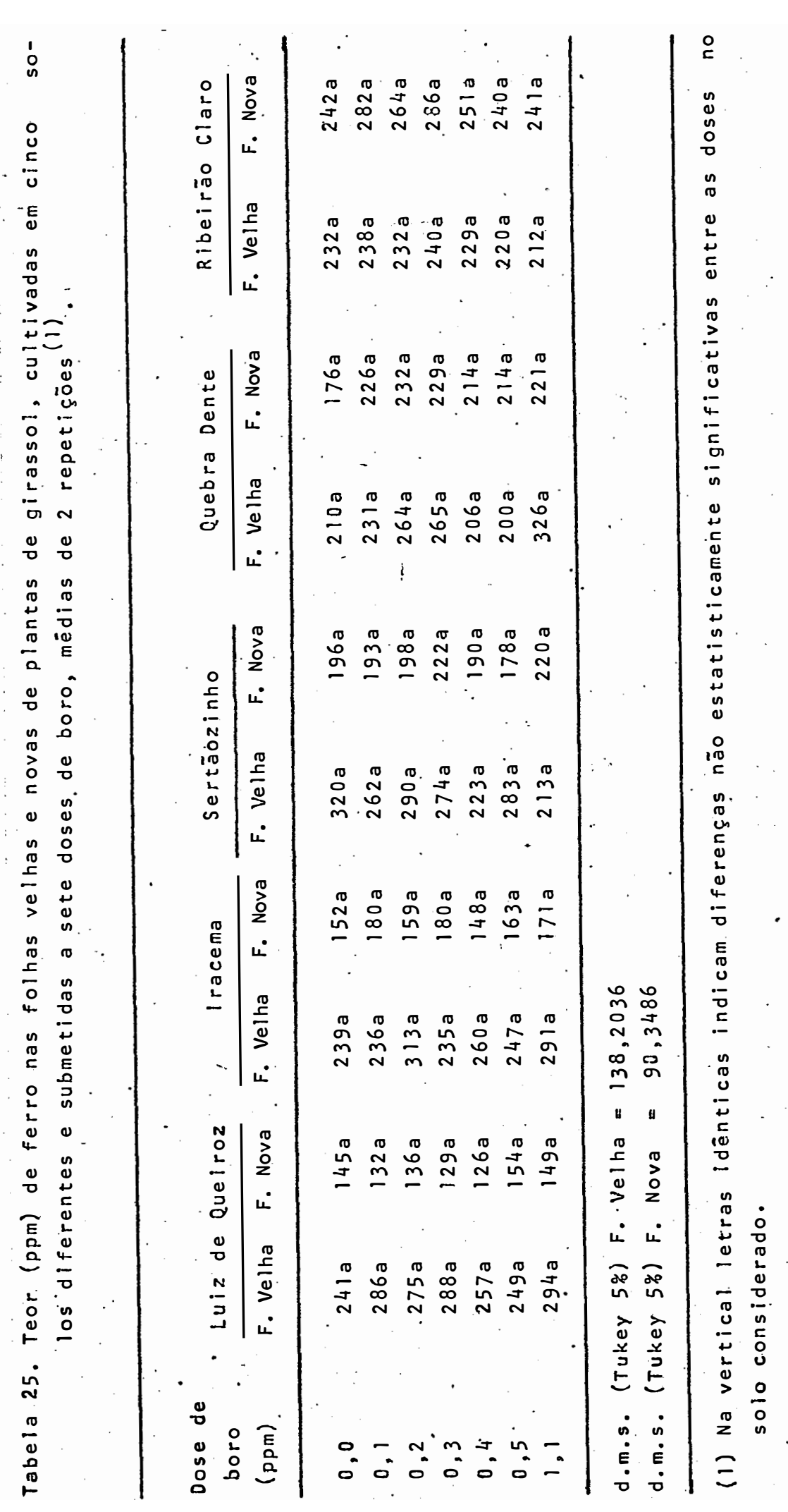




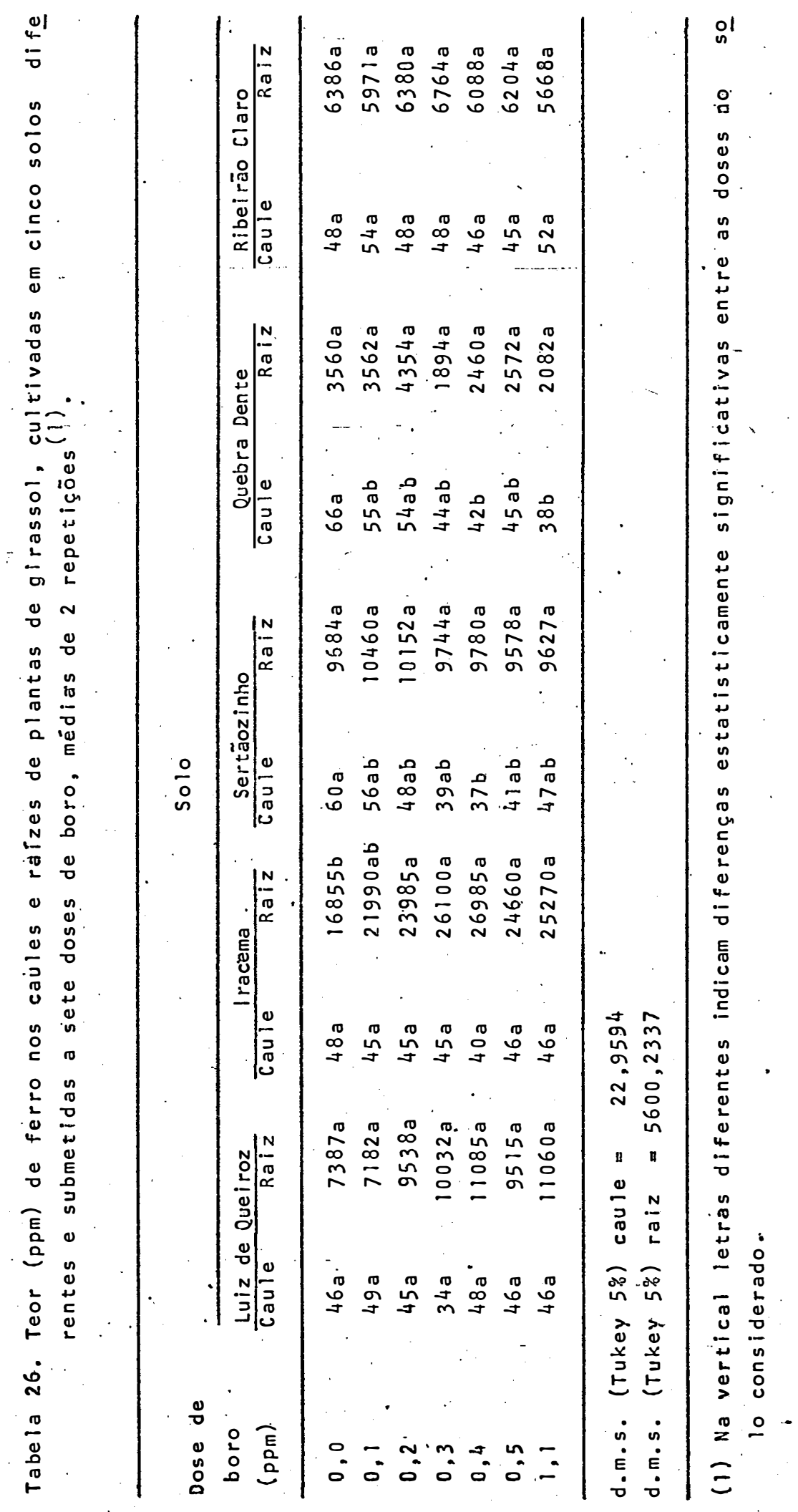




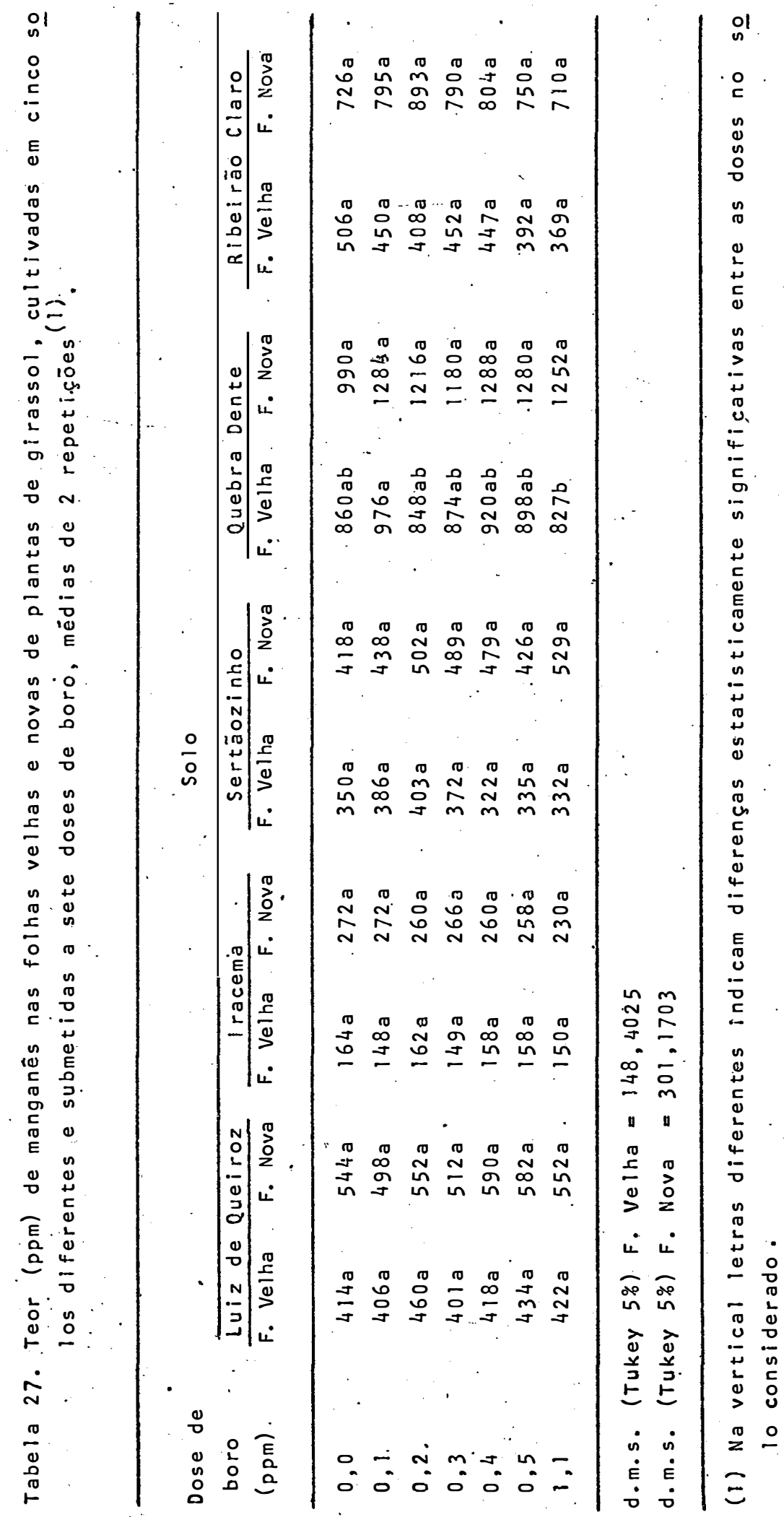

.61. 


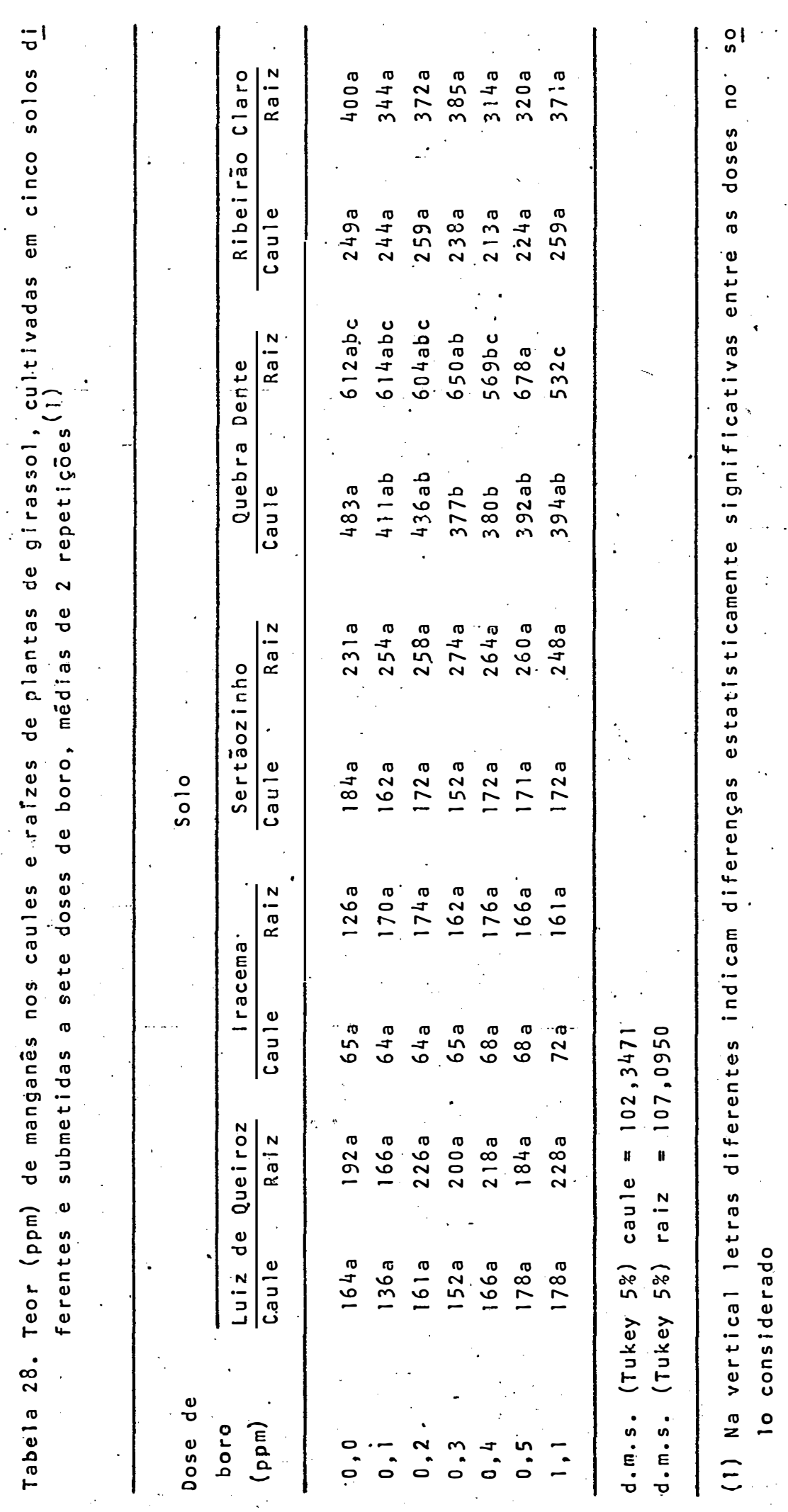

.62. 
.63 .

dadas das plantas de girassol. Quando os dados são observa dos em conjunto observa-se que os teores de nitrogênio, fós foro, cálcio, magnēsio, zinco e cobre, em geral, diminuiram com o aumento da dose de boro, enquanto que os teores de po tássio, enxofre, ferro e manganês praticamente não foram afe tados pelas doses crescentes de boro.

Tomando-se como referência os valores da com posição mineral das plantas, no solo Qụebra Dente, que foi ví sualmente e quimicamente o solo mais deficiente em boro, temse que apenas para o fósforo, magnésio e enxofre houve o mes mo comportamento nas quatro partes estudadas das plantas, o correndo uma diminuição dos teores destes macronutrientes com o aumento das doses de boro. Pára os demais nutrientes estudados não houve comportamento uniforme em função das do ses de boro para as quatro partes em estudo. Os resultados obtidos neste ensaio não permitiram conclusões como as obti das por BAKER e COOK. (1956) que observaram nas porções api cai.s de plantas de alfafa deficientes em boro menores teores de boro, potássio, călcio e magnésio do que nas partes máis velhas das plantas, sendo o. reverso verdadeiro para plantas não deficientes. O efeito dé doses de boro aplicadas ao solo sobre os teores de outros nutrientes nas diversas partes das plantas necessita de maiores pesquisas podendo, talvez, va riar com a espécie vegetal, visto que ELLIOTT e NELSON (1981) nao constataram em plantas de begônia efeito de doses crescen 
tes de boro sobre os teores foliares de nitrogênio, fósforo, potässio, călcio, magnésio, cobre, ferro, manganês e zinco.

Com relação ao boro em todos os solos estuda dos houve efeito estatisticamente significativo de doses de boro sobre os teores nas folhas novas e folhas velhas, no en tanto, em nenhum dos cinco solos houve efeito das doses de boro sobre o teor do micronutriente nos caules e raizes ( $T$ a bela 29).

As Tabelas 30 e 31 mostram os teores (ppm) de boro nas partes das plantas de girassol. Em todos os solos os teores de boro das folhas novas e velhas no tratamento $1 ; 1$ ppm de B foram estatisticamente superiores aos tratamentos 0,$0 ; 0,1$ e 0,2 de boro havendo, portanto, efeito marcante das doses de boro sobre os teores do micronutriente nas folhas o que não ocorreu com as raízes e caules. Quantitativamente os teores nas folhas não aumentaram proporcionalmente ao aumen to da dose de boro o que está.de acordo com o obtido por ME $\underline{S}$ QUITA FILHO e' OLIVEIRA (1984) e conträrio à constatação de PETERSON e NEWMAN (1976). Ao observar-se os valores do teste F (Tabela 29), bèm como os vàlores dos coeficientes de corre laçao linear e quadrätico (Tabela 32 ), conclui-se que as fo lhas novas säo a parte da planta mais sensível à disponibili dade de boro, seguidas pelas folhas velhas, enquanto que os caules e as raízes não se mostraram bom indicadores da dispo 


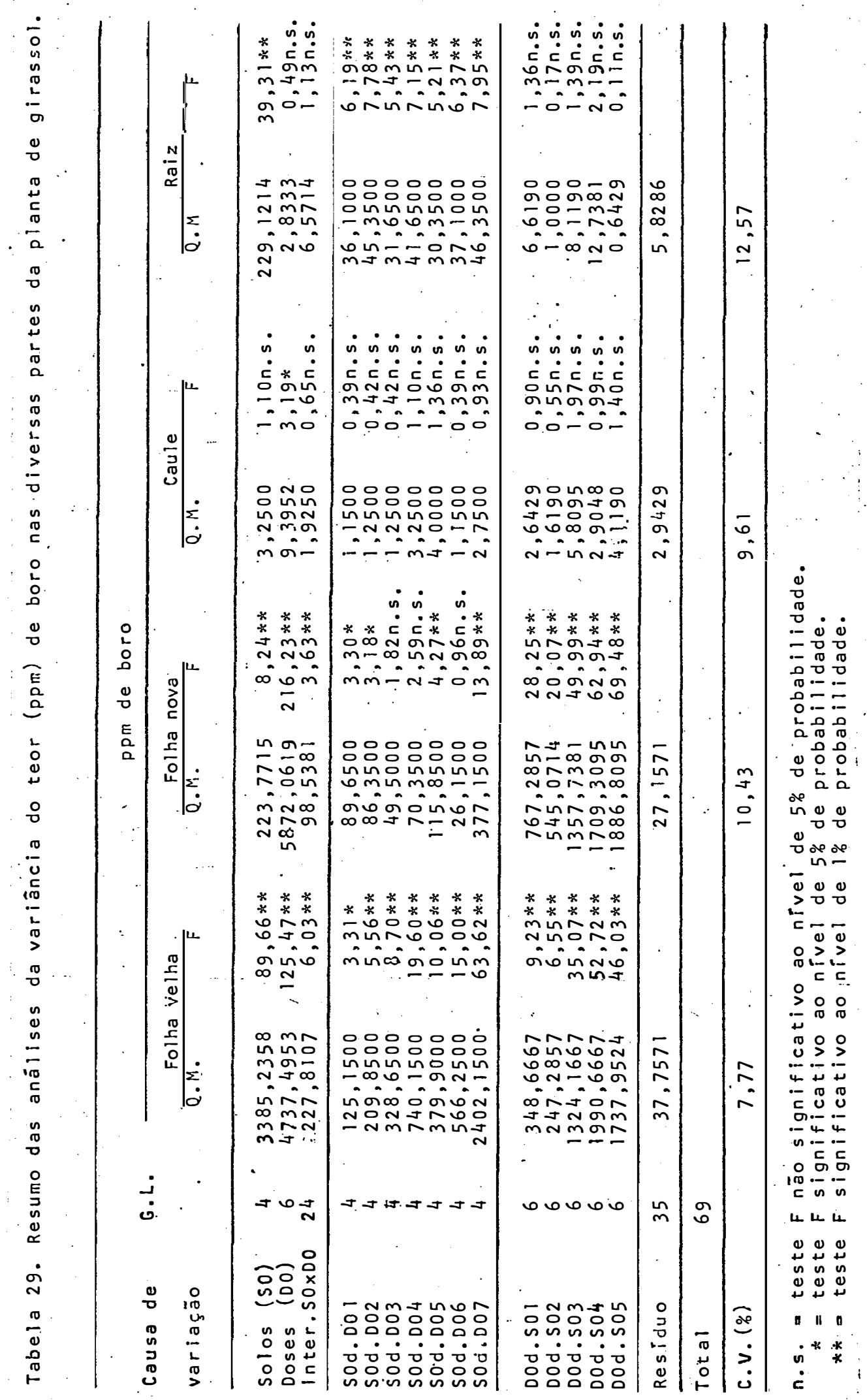


.66.

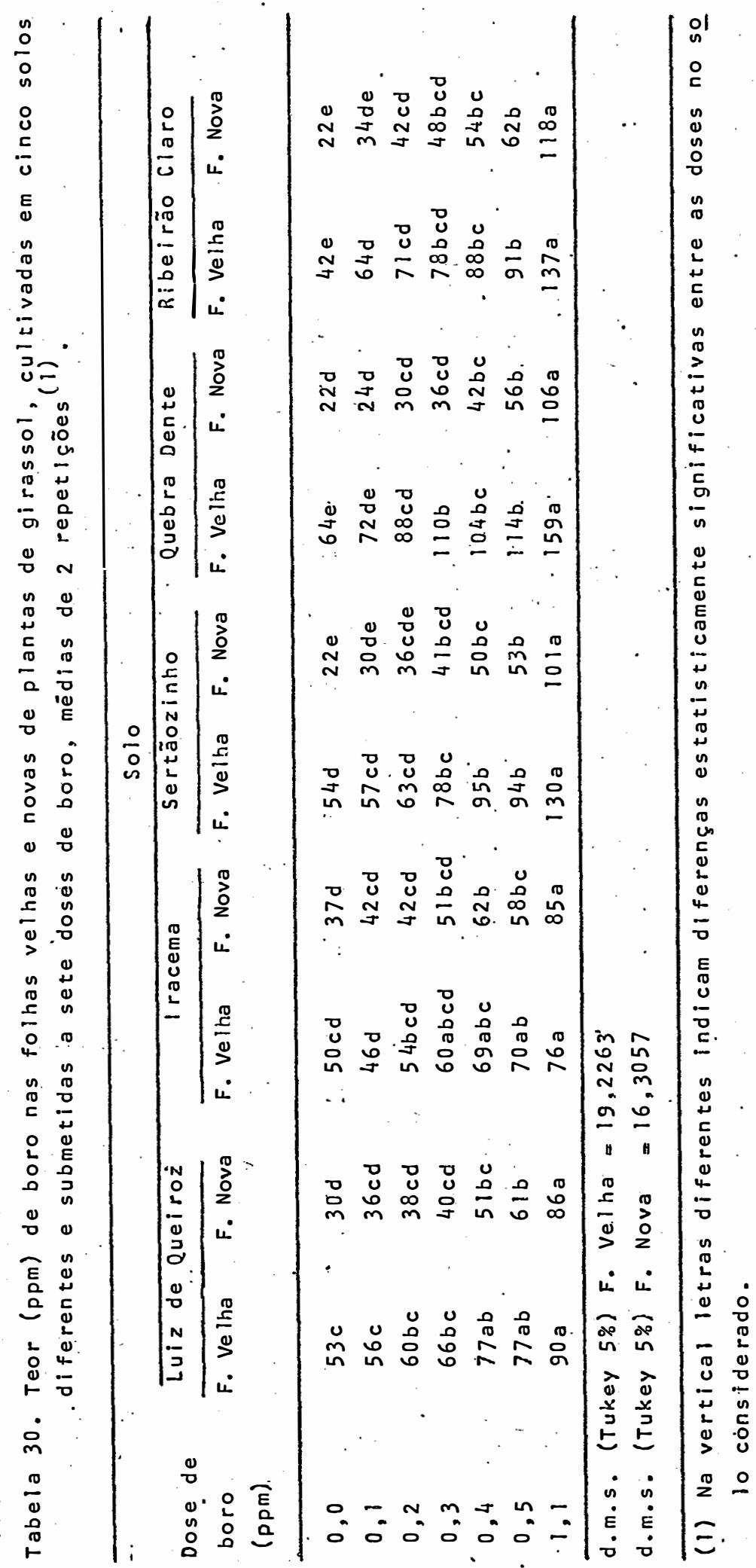


.67.

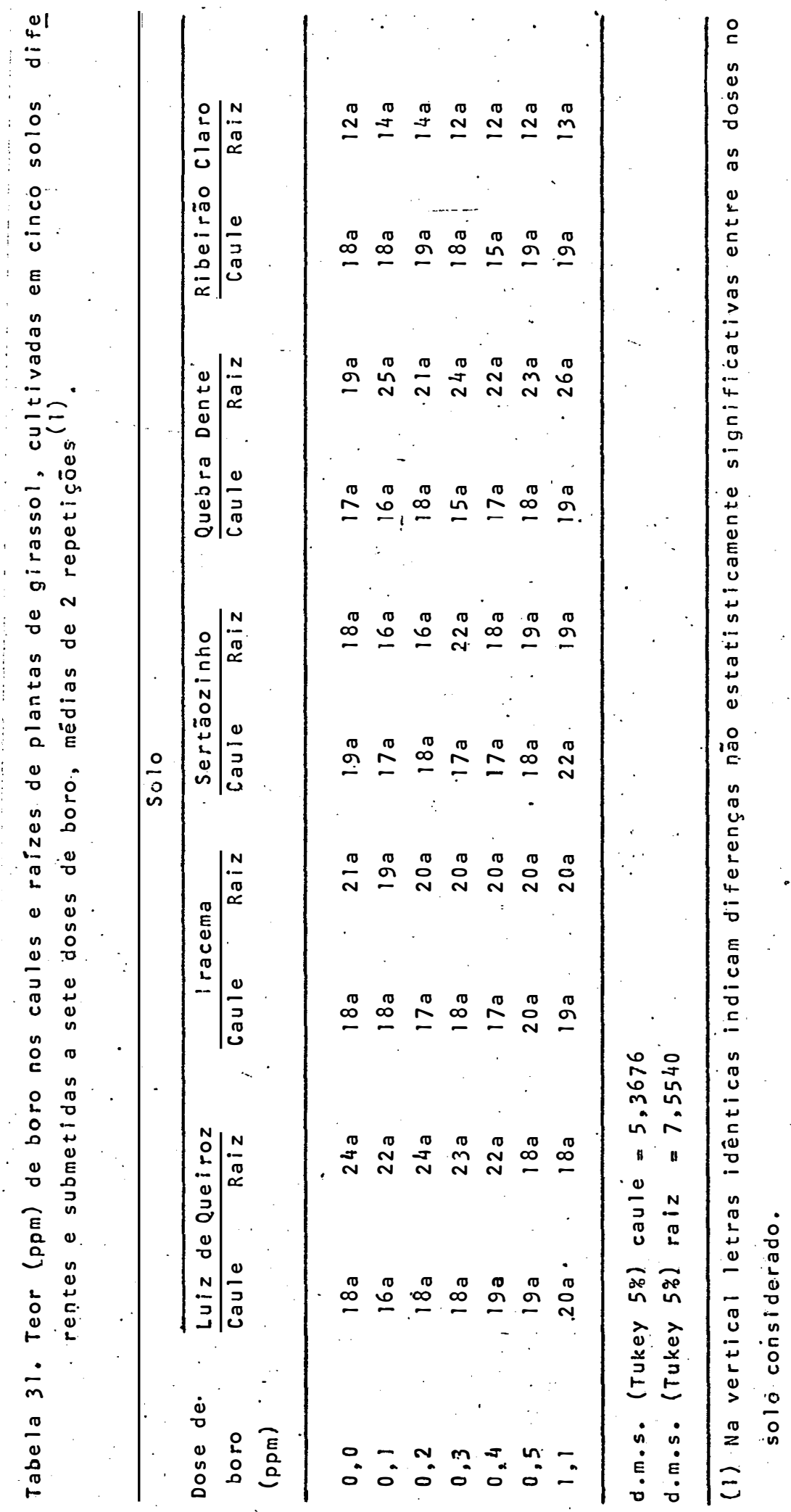


.68 .

Tabela 32. Coeficientes de correlação linear e quadrätico en tre a dose de boro e o teor (ppm) do micronutrien te nas folhas velhas e novas de plantas de giras sol.

\begin{tabular}{|c|c|c|c|c|}
\hline & \multicolumn{4}{|c|}{ Coeficiente de correlação } \\
\hline & \multicolumn{2}{|c|}{$=\quad$ Linear } & \multicolumn{2}{|c|}{ Quadrático } \\
\hline & F. Velha & F. Nova & F. Velha, & $\bar{F}$. Nova \\
\hline Luiz de Queiroz & $0,8844 * * *$ & $0,9740 * * *$ & $0,9518 * * *$ & $0,9743^{* * *}$ \\
\hline I racema & $0,6870 * *$ & $0.9480^{*} * *$ & $0,8411 * * *$ & $0,9503^{* * *}$ \\
\hline Sertäozinho & $0,9642 * * *$ & $0,9900 * * *$ & $0,9702 * * *$ & $0,9912 * * *$ \\
\hline Quebra Dente & $0,9583 * * *$ & $0,9799 * * *$ & $0,9682 * * *$ & $0,9872 * * *$ \\
\hline Ribei rão Claro & $0,9614 * * *$ & $0,9842 * * \dot{x}$ & $0,9668 * * *$ & $0,9854 * * *$ \\
\hline
\end{tabular}


nibilidade de boro.

\subsubsection{QUANTIDADES ABSORVIDAS DE BORO EM FUNÇÃO DA DOSE DESTE MICRONUTRIENTE}

Com base nos valores do teste $F$ podemos con cluir que o efeito de doses foi maior que o de solos (Tabela 33), havendo em todos os solos estudados efeito estatistica mente significativo das doses de boro sobre a quantidade do micronutriente absorvida pelas plantas de girassol. (Tabela 33). Em todos os solos as quantidades absorvidas (microgra mas/vaso) no tratamento l, l ppm de boroforam estatisticamen te superiores ao tratamento testemunha (Tabela 34 ), bem como as correlações entre as doses de boro e a quantidade absorvi da. pelas plantas foram significativas a $0,1 \%$ de probabilida de em todos os solos estudados (Tabela 35).

\section{4,4, BORO NO SOLO}

\subsubsection{TEOR INICIAL}

For am calculadas as produções e alturas rela . tivas para cada solo da seguinte maneira: produção relati $v a=$ média da produção de matēria seca do tratamento que não recebeu boro/média do tratamento que apresentou a maior pro dução, altura relativa = média do tratamento que não recebeu 
.70 .

Tabela 33. Resumo das anālises da variància da quantidade de bo ro absorvida (microgramas/vaso) pór plantas (parte aérea+raiz) de girassol.

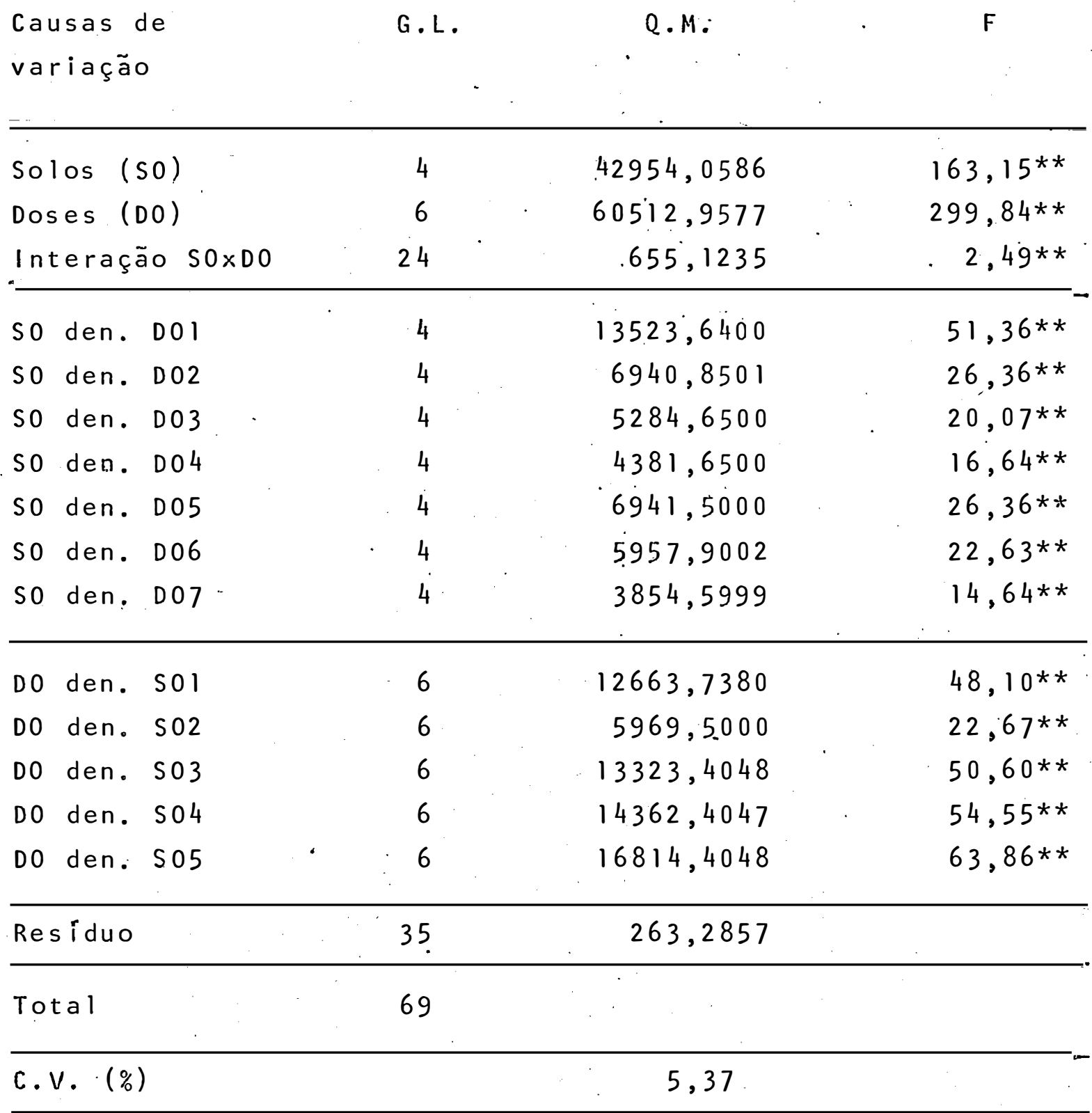

** = teste F significativo ao nivel de $1 \%$ de probabilidade. 


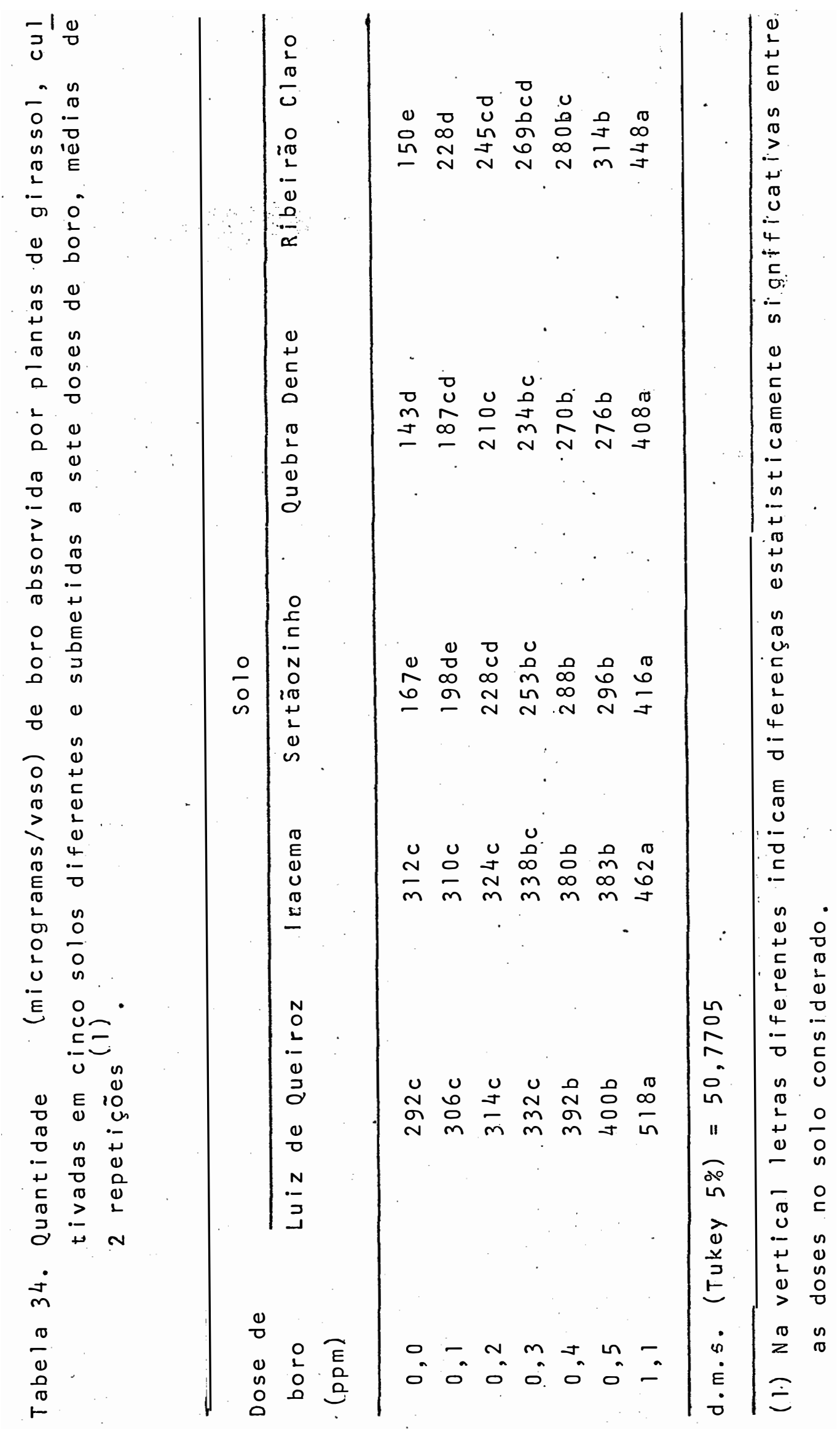


Tabela 35. Coeficientes de correlação linear e quadrático en tre a dose de boro e a quantidade absorvida (mi crogramas/vaso) do micronutriente por plantas de girassol.

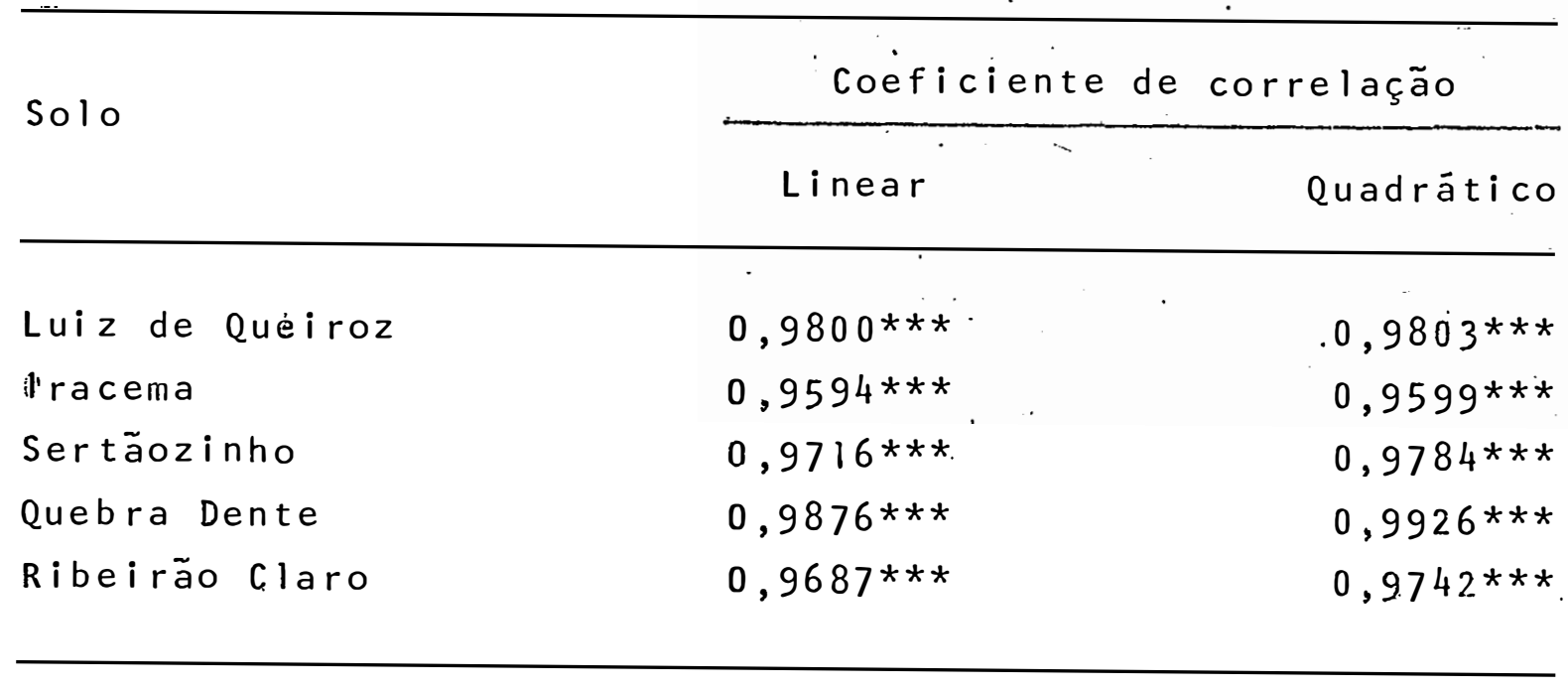

$* * *=$ teste $F$ significativo ao nivel de $0,1 \%$ de probabilidade. 
boro/média do tratamento que apresentou'a maior altura (Tabe la 36 ).

$$
\text { Adotando-se o critērio de RAlJ (1974) de que }
$$
os limites de classes de fertilidade são dados pela produção relativa que varia de 0 a $50 \%$ para teores muito baixos, 51 a 75\% para teores baixos, 76 a $90 \%$ para teores médios, 91: a. $100 \%$ para teores altos e acima de $100 \%$ para teores muito al tos, tem-se a relação à produção relativa de matéria secalfí gura 1) O seguinte: para O HEl $0,05 \mathrm{M}$ teores menores ou iguais a 0,31 ppm são baixos, entre 0,31 a 0,50 ppm são médios e acima de $0,50 \mathrm{ppm}$ são altos; para o $\mathrm{NH}_{4} \mathrm{Ac} 1,0 \mathrm{~N}, \mathrm{pH} 4,8$ teo res menores ou iguais a 0,18 ppm são baixos, entre 0,18 a 0,27 ppm são médios e acima de 0,27 ppm são altos; para a ä gua quente teores menores ou iguais a 0,26 ppm são baixos, entre 0,26 a $0,41 \mathrm{ppm}$ são médios e acima de 0,41 ppm são al tos. Extrapolando-se os critérios de RAlJ (1974) de produção relativa de matéria seca para altura relativa (Figura 2) temse que para o HCl 0,05 M teores menores ou iguais a $0,36 \mathrm{ppm}$ são baixos, entre 0,36 a 0,49 ppm são médios e acima de $0 ; 49$ ppm são altos, para o $\mathrm{NH}_{4} \mathrm{Ac} 1,0 \mathrm{~N}, \mathrm{pH} 4,8$ teores menores ou iguais a $0,18 \mathrm{ppm}$ são baixos, entre 0,18 a $0,25 \mathrm{ppm}$ são mé dios e acima de 0,25 ppm são altos; para a āgua quente teo res menores ou iguais a $0,32 \mathrm{ppm}$ são baixos, entre 0,32 a 0,42 ppm são médios e acima de 0,42 ppm são altos. 0s 1 i mites de classes de fertilidade são semelhantes para os três extratores quer se utilize altura ou produção 


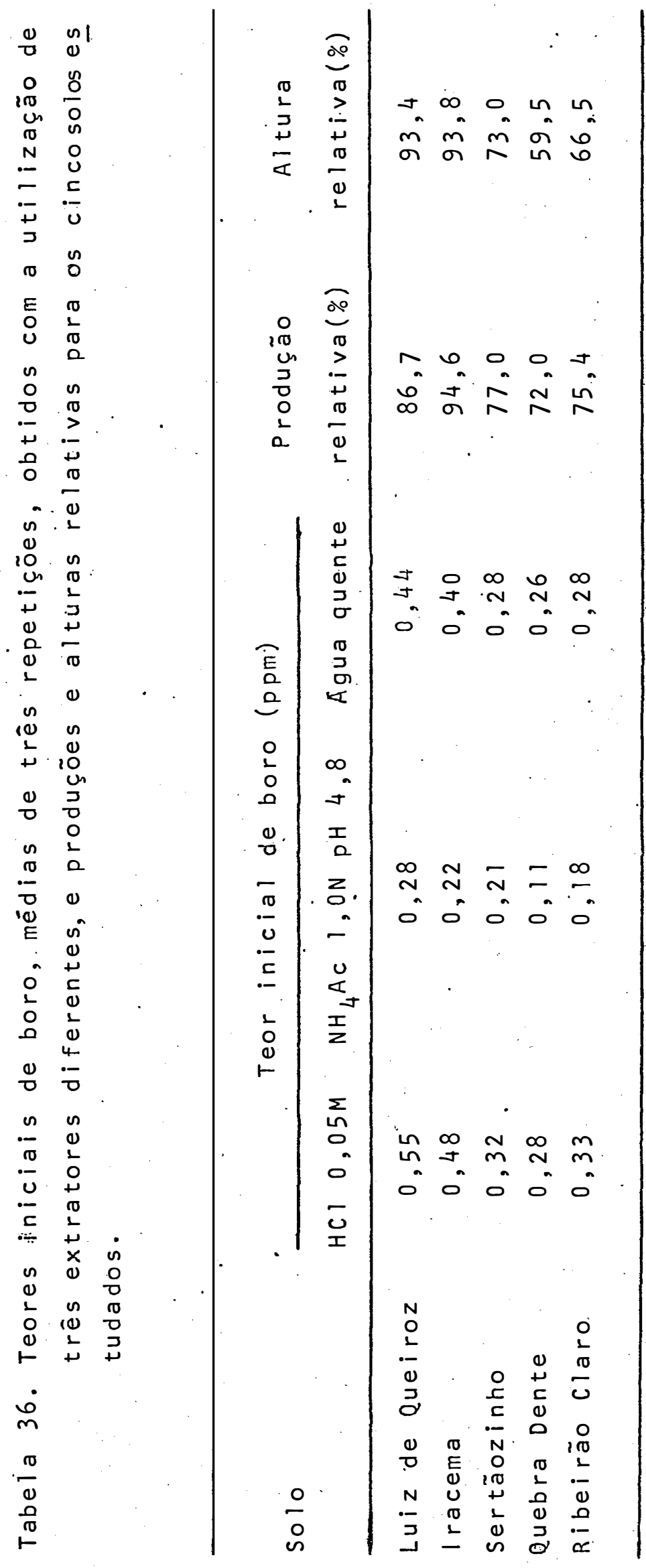

.74. 


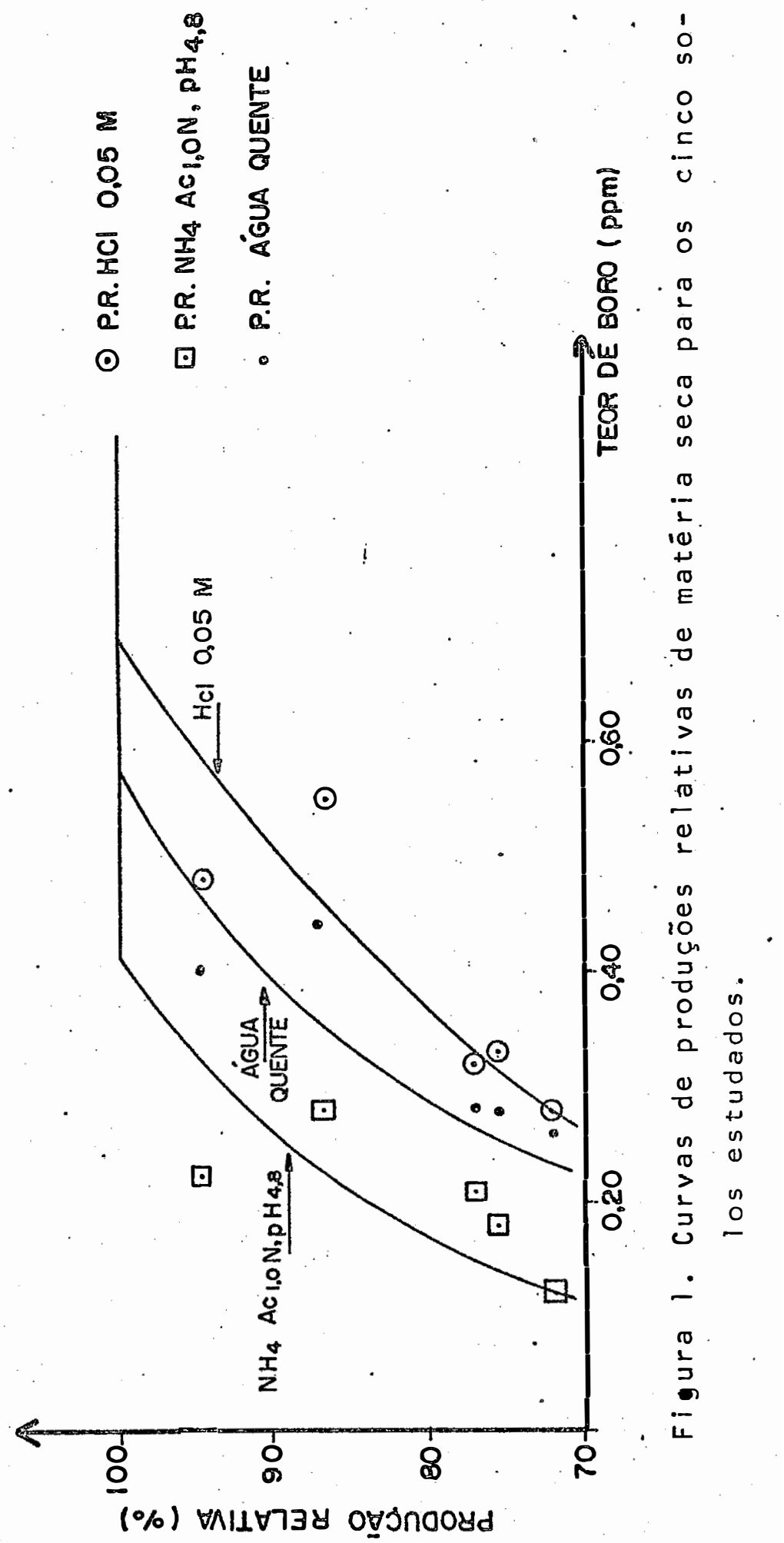


.70.

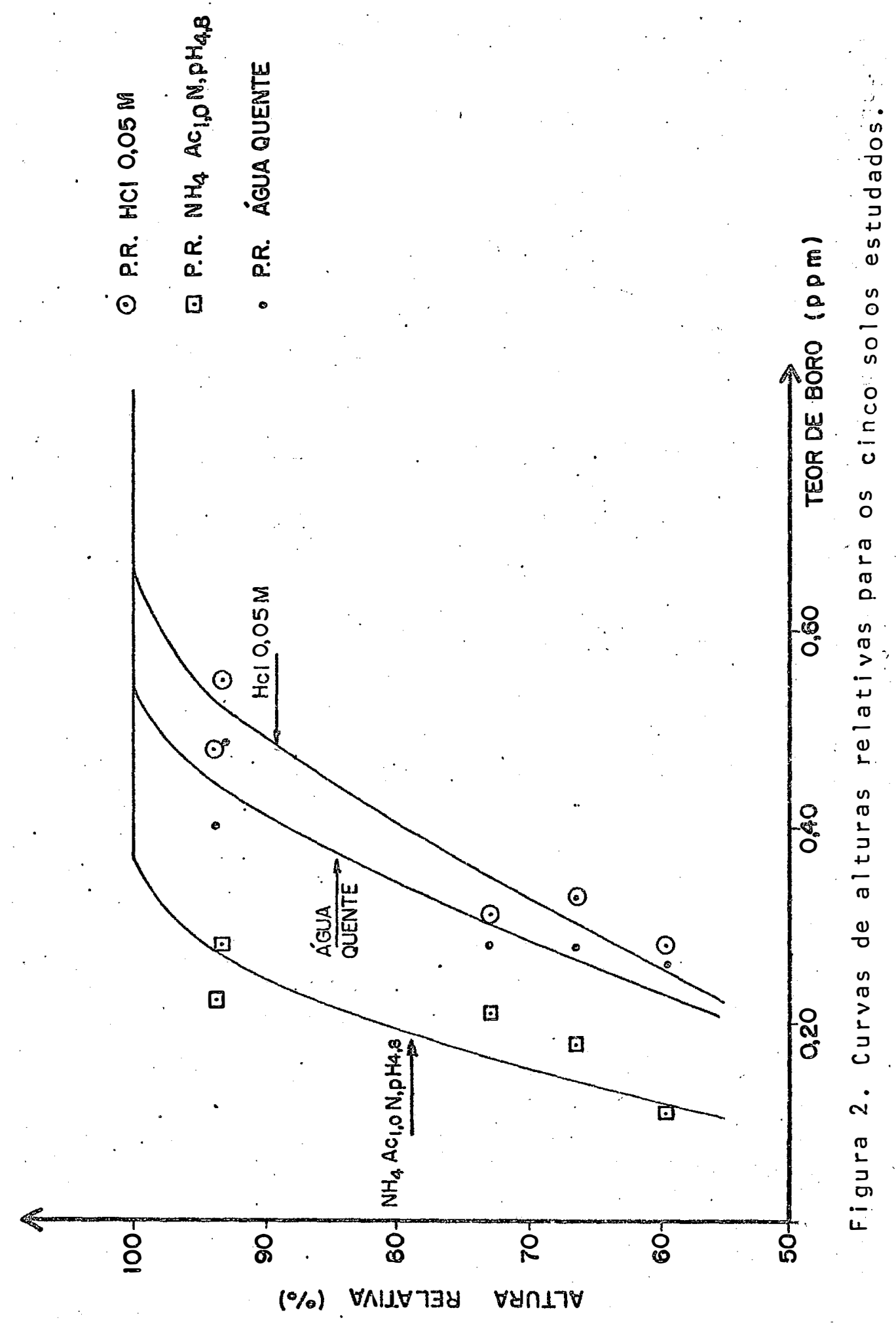


relativa, no entanto, pode-se observar que o intervalo. da classe média de fertilidade è menor, para os três extratores, quando o parâmetro utilizado é a altura relativa.

os coeficientes de correlação linear entre os teores iniciais de boro no solo extraídos pọ três extratores diferentes foram: $\mathrm{HCl} 0,05 \mathrm{M} \times$ acetato de amônio $1,0 \mathrm{~N}, \mathrm{pH} 4,8$ $\left(r^{\prime}=0,8647\right.$ n.s.), HCl $0,05 M \times$ ägua quente $\left(r^{\prime}=0,9969 * * *\right)$ e acetato de amônio $1,0 \mathrm{~N}, \mathrm{pH} 4,8 \times$ àgua quente $\left(r^{\prime}=0,8356\right.$ n.s.), portanto, O HCl $0,05 \mathrm{M}$ e a ágụa quente foram os extratores que apresentaram o maior coeficiente de correlação linear para o teor inicial de boro do solo, seguidos pelo $\mathrm{HCl} 0,05 \mathrm{M} \times \mathrm{NH}_{4} \mathrm{Ac}$ $1,0 \mathrm{~N}, \mathrm{pH} 4,8$, com menor valor para $\mathrm{NH}_{4} \mathrm{Ac} 1,0 \mathrm{~N}, \mathrm{pH}_{4}, 8 \times$ áqua quente.

Atravēs do conhecimento dos, teores de boro an tes e apōs o cultivo das plantas de girassol pode-se: comparar as quantidades de boro extraídas pelas plantas com as diferen ças entre as quantidades iniciais e finais indicadas pelos extratores ( $T$ abela 37 ). Os coeficientes de correlação linear foram em ordem decrescente $0,1372 \mathrm{n} . \mathrm{s}$. para o $\mathrm{HCl} 0,0.5 \mathrm{M}$, 0,0220 n.s. para $0 \mathrm{NH}_{4} \mathrm{Ac} 1,0 \mathrm{~N}, \mathrm{pH} 4,8$ e 0,0164 n.s. para a água quente. O HCl 0,05 M para todos os solos estudados foi o método que mais se aproximou em valores absolutos das quanti dades extraídas pelas plantas, vindo em seguida a çaua auen te. Pode-se observar que as quantidades de boro extraídas pelos extratores foram inferiores às extráidas pelas plantas o que já tinha sido constatado por McCLUNG e DAWSON (1950) e BAKER 


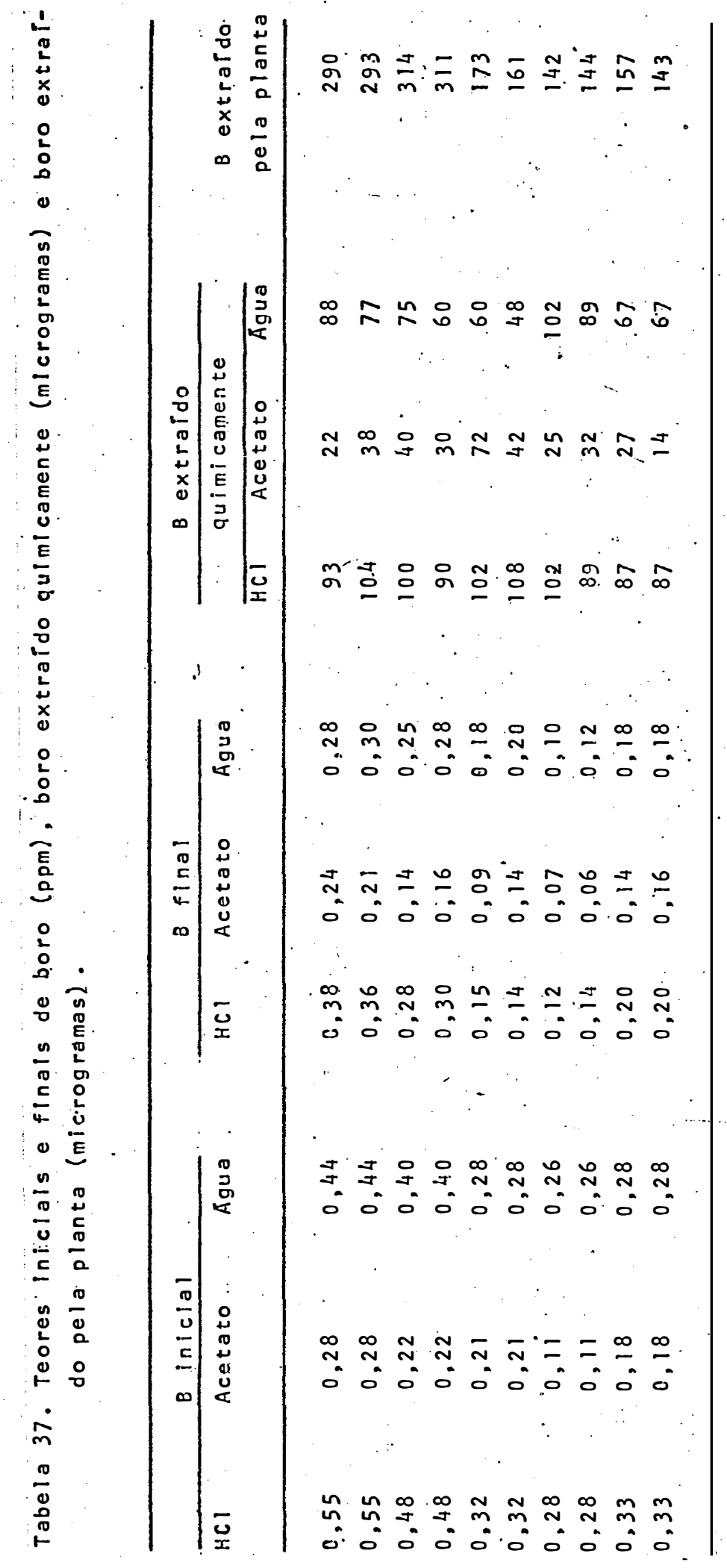


(1971), o que leva à conclusão de que os extratores estuda dos retiraram do solo apenas uma fraçã் do boro disponível às plantas.

A àgua quente foi o extrator que apresentou as maiores correlações entre o teor inicial e a quantidade de boro absorvida pelas plantas, enquanto o $\mathrm{NH}_{4} \mathrm{Ac} 1,0 \mathrm{~N}, \quad \mathrm{pH}$ 4,8 apresentou os menores valores para as correlações linear e quadrātica (Tabela 38), señdo a ägua quente, segundo o cri tério de RAIJ (1981), o melhor extrator. Com relação aos teo res de boro na planta as folhas novas foram, para os três ex tratores, a parte da planta que melhor se correlacionou :com o teor inicial de boro no solo, com. a ägua quente apresentan do os maiores coeficientes de correlação, vindo o $\mathrm{HCl} 0,05 \mathrm{M}$ em seguida; após as folhas novas as partes das plantas que apresentaram maiores correlações com os teores iniciais ! do solo obtidos pelos três extratores diferentes foram em ordem decrescente as raízes, folhas velias e caules, os quais não mostraram correlações significativas entre os seus teores de boro e as quantidades de boro absorvidas pelas plantas, ao passo que o teor de boro nas. folhas novas foi altamente cor relacionado com as quantidades de boro absorvidas. 0 ifato dos valores dos coeficientes de correlação linear e quadrātico entre o teor de boro nas folhas novas e as quantidades de bo ro absorvidas pelas plantas terem sido superiores aos valores 
.80 .

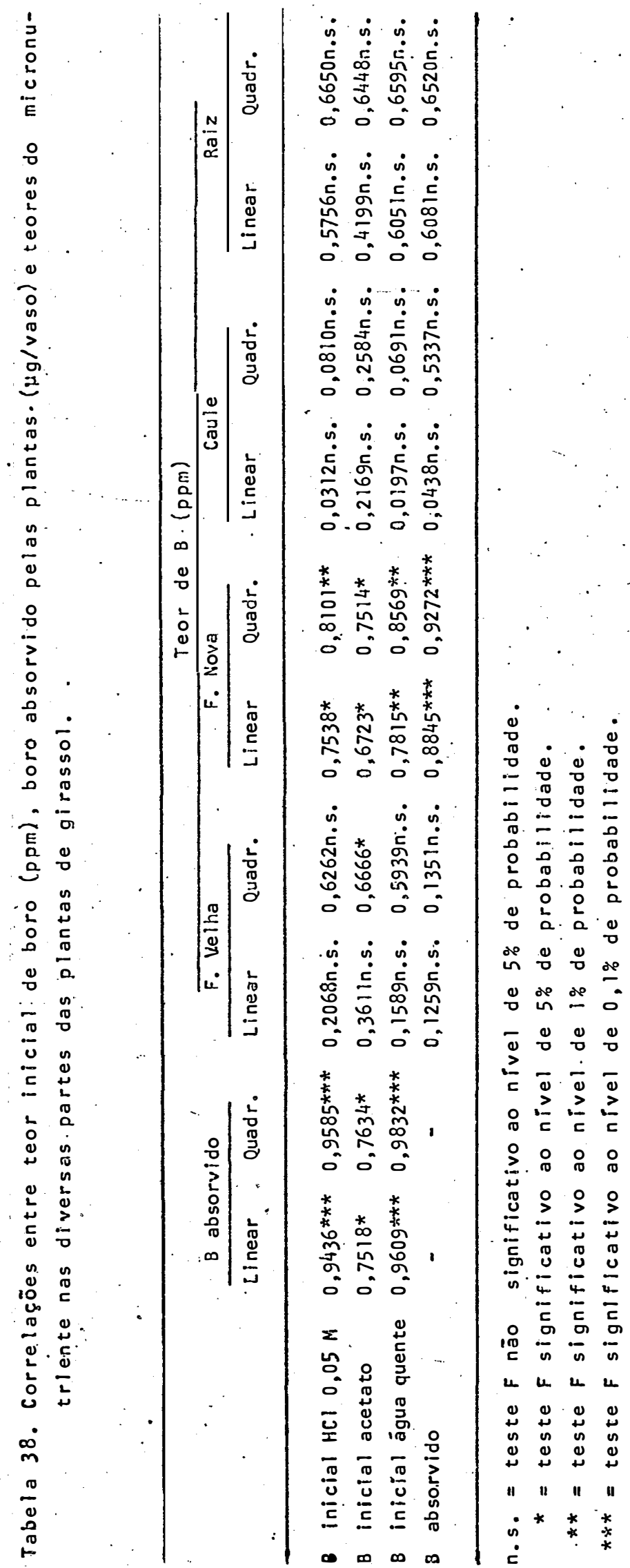


dos mesmos coeficientes observados para as correlações entre teor inicial de boro e quantidade absorvida do micronutrien te leva à conclusão de que para avaliar a disponibilidade de boro talvez seja melhor analisar as folhas novas com relação a este micronutriente do que os solos, o que está de acordo com o obtido por BAKER e COOK (1959).

Foi observado que os solos Luiz de Quéiroz e Iracema, que possuem maior quantidade de argila. (Tabela 2), apresentaram maiores quantidades de boro disponível, obtidos pelos três extratores estudados que os arenosos (Tabela 36). - que está de acordo com o relatado por. GUPTA (1968), OBUKHOV (1968), BRASIL SOBRINHO (1965) e CASAGRANDE (1978).

\subsubsection{TEOR FINAL}

Houve efeito estatisticamente significativo das do ses de borosobre o teor final (ppm) do nutriente em todos os. solos estudados para os três extratores (Tabela 39). os teores finais de boro obtidos pelos trẹs diferentes extrato res encontram-se nas Tabelas 40,41 e 42 , onde pode-se obser var que houve efeito de doses sobre os teores finais de boro obtidos pelos três diferentes extratores, o que jä tinha si do observado por PETERSON e NEWMAN (1976). O tratamento 1,1 ppm de boro diferiu estatisticamente, ao nivel de $5 \%$ de pro babilidade, do tratamento testemunha para todos os solos e extratores estudados, exceção feita ao acețato de amônio 1.,0 


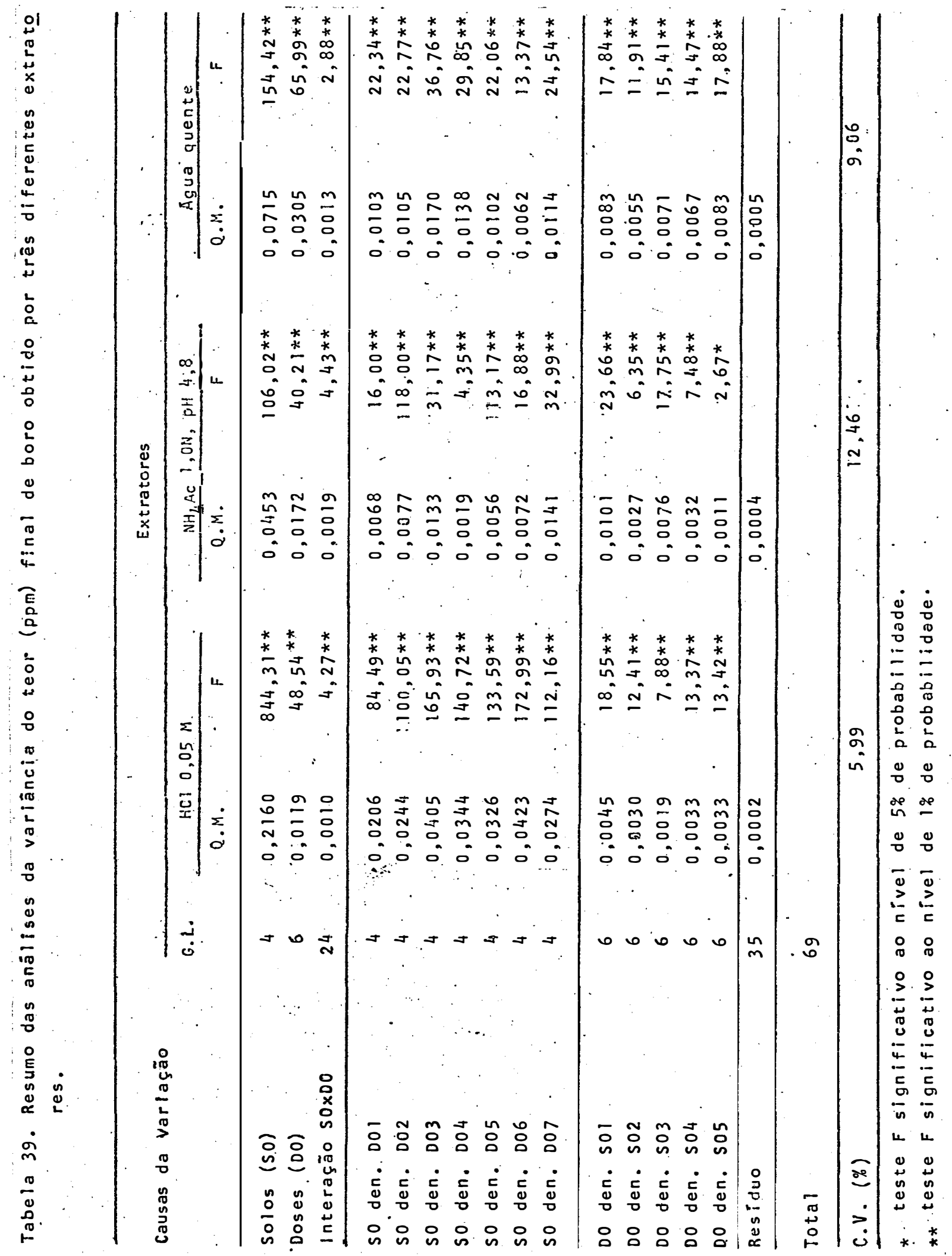




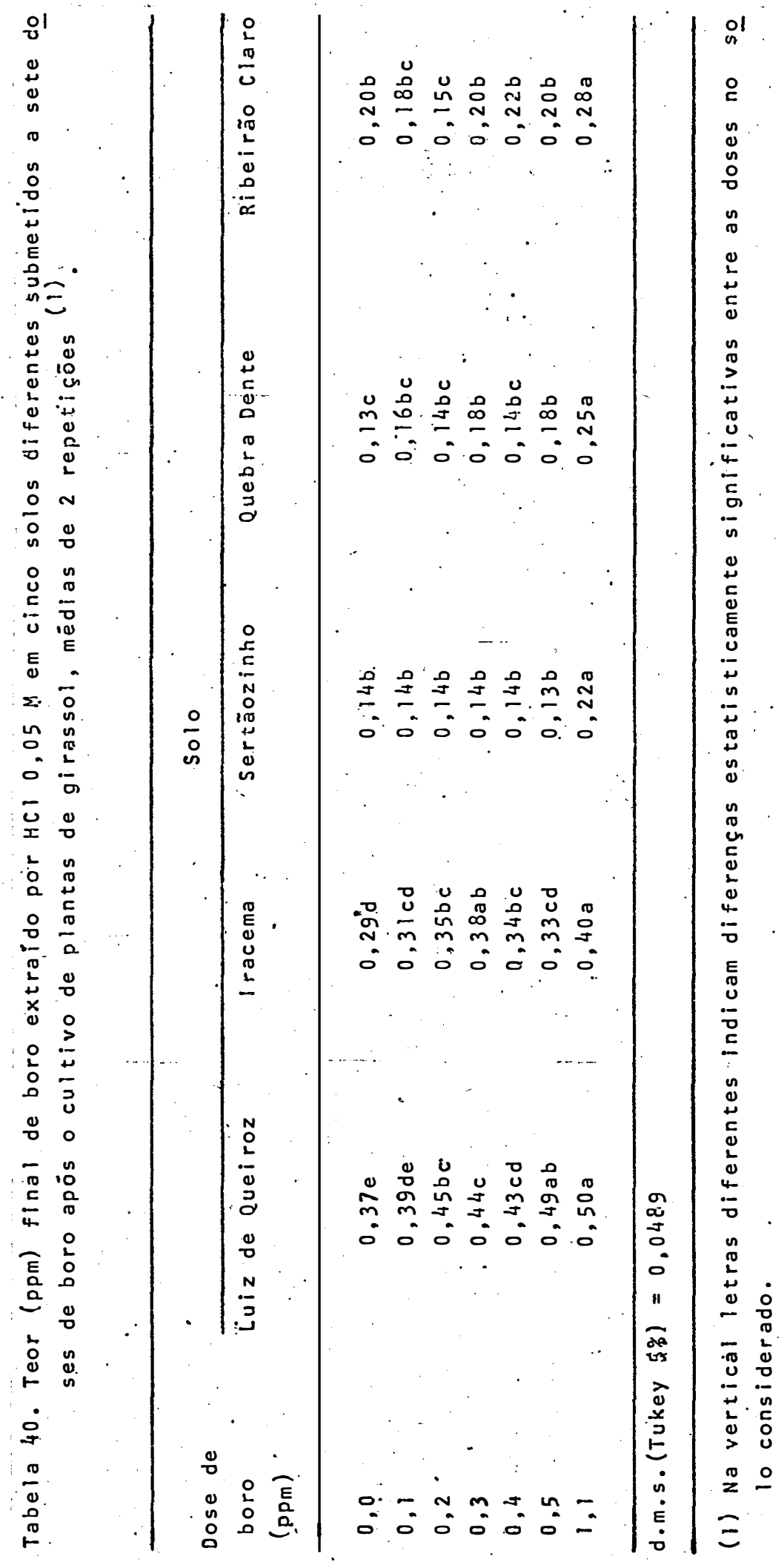




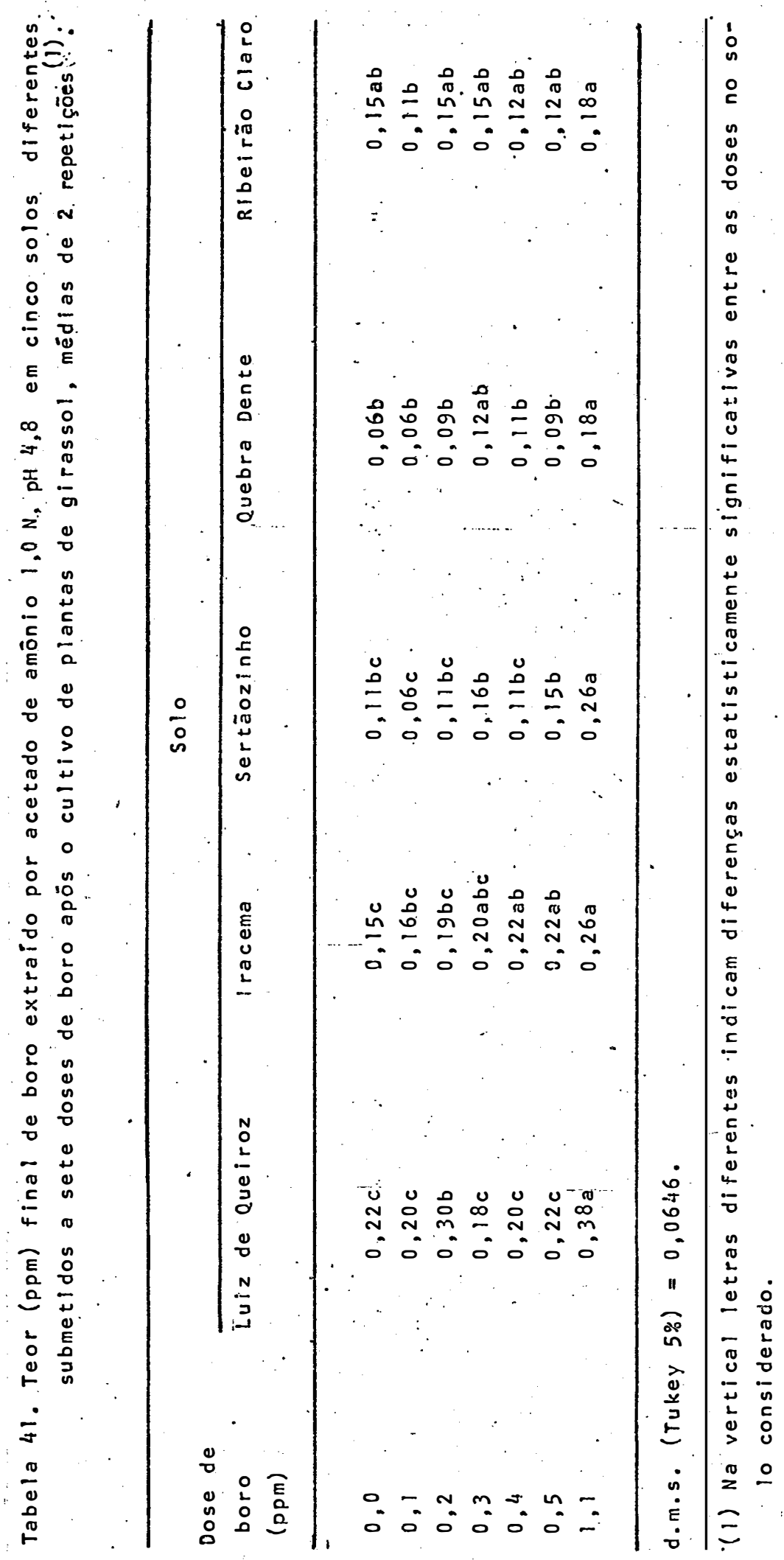

.84. 


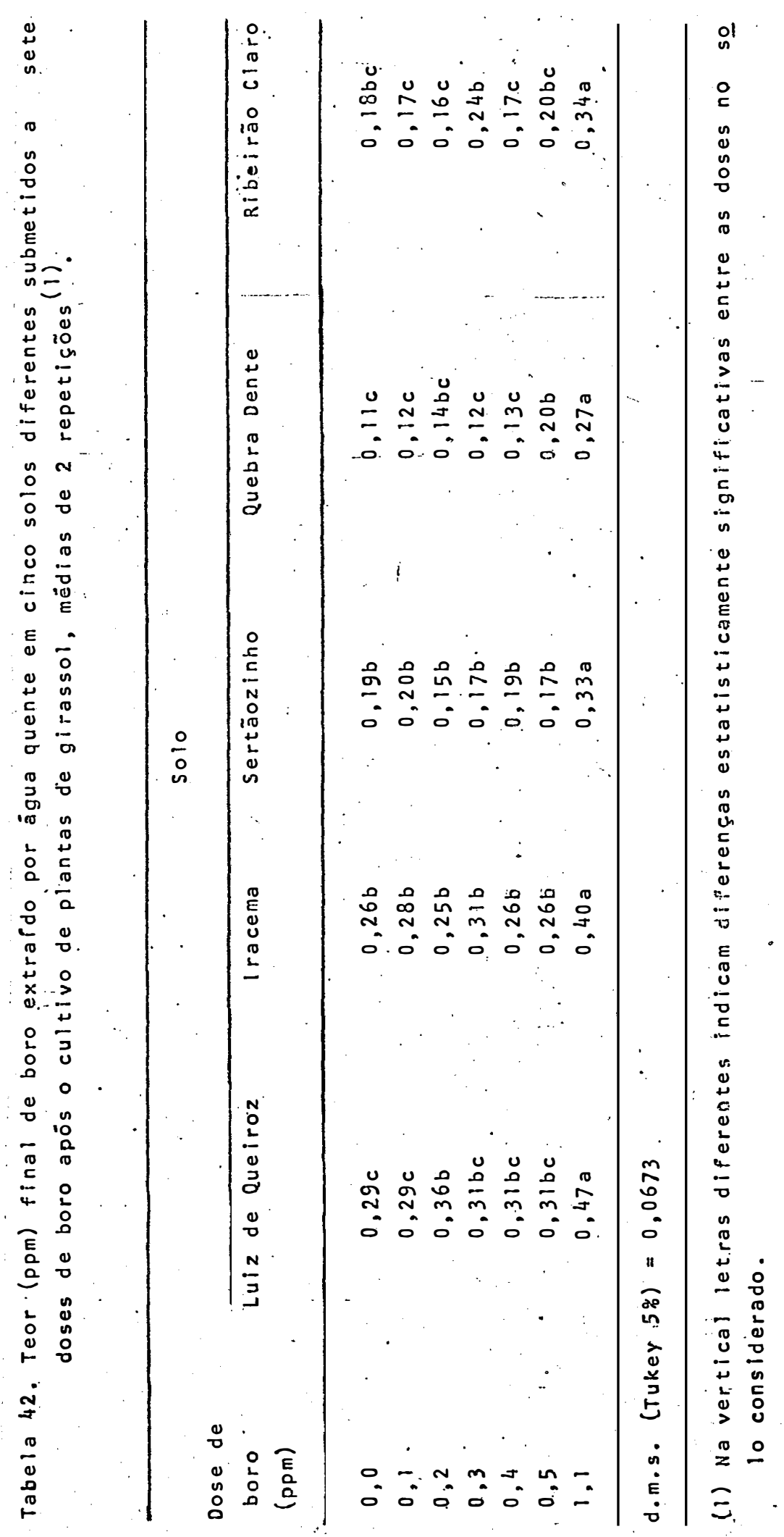


.86.

N, pH 4,8 no solo Ribeirão Claro. Pelos valores do teste. F (Tabela 39) pode-se observar que a ăgua quente foi o extra tor mais sensível às doses de boro nos solos Quebra Dente e Ribeirão Claro, ficando na segunda posição nos solos I racema e Sertãozinho e em terceiro lugar no solo Luiz de Queiroz, o acetato de amónio $1,0 \mathrm{~N}, \mathrm{pH} 4,8$ foi o mais sensível nos so los Luiz de Queiroz e Sertãozinho, enquanto o HCl 0,05 M foi o mais sensível no solo I racema. Com base no fato de que é mais vantajoso o extrator ser sensívei quando os teores do elemento no solo são baixos e não quando estes são elevados, podemos concluir com base nos teores finais de boro no solo que a àguạ quente foi o melhor extrator.

Os coeficientes de correlação linear dos teo res finais de boro, obtidos por três extratores. diferentes, entre si e com as medidas de crescimento e as anälises dos tecidos das plantas, nos cinco solos estudados, encontram-se nas Tabelas $43,44,45,46$ e 47 . Quanto às correlações dos teores finais com os teores de boro nas folhas velhas houve variação de solo para solo não se podendo concluir quà ex trator apresenta melhor correlação com os teores de boro des ta parte da planta. Com reláção às folhas novas a primeira evidência é que os teores de boro nas folhas novas foram me lhores correlacionados com os teores finais do micronutrien te no solo que nas folhas velhas, sendo que novamente não se pode concluir sobre qual extrator apresenta as melhores cor 


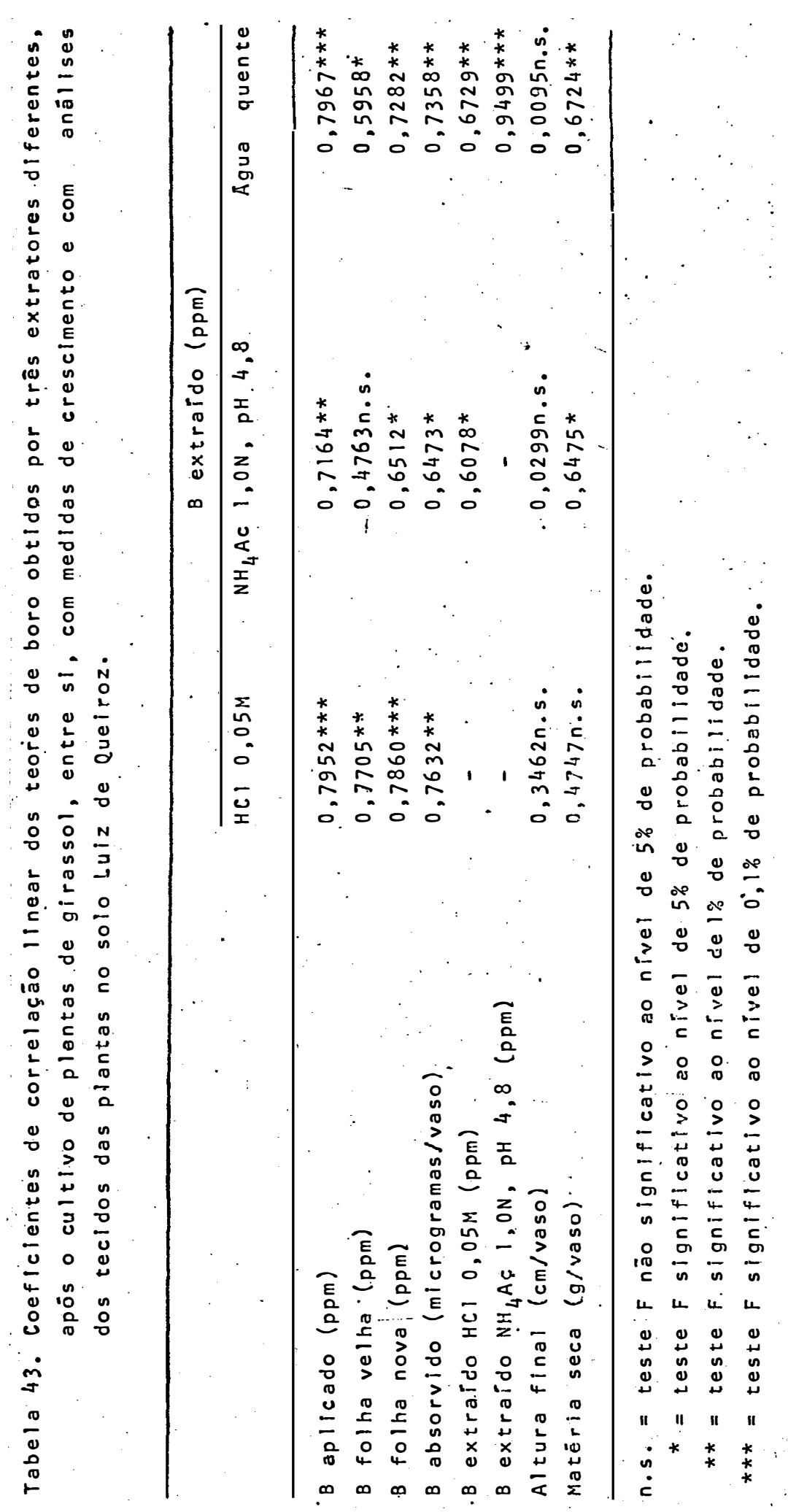




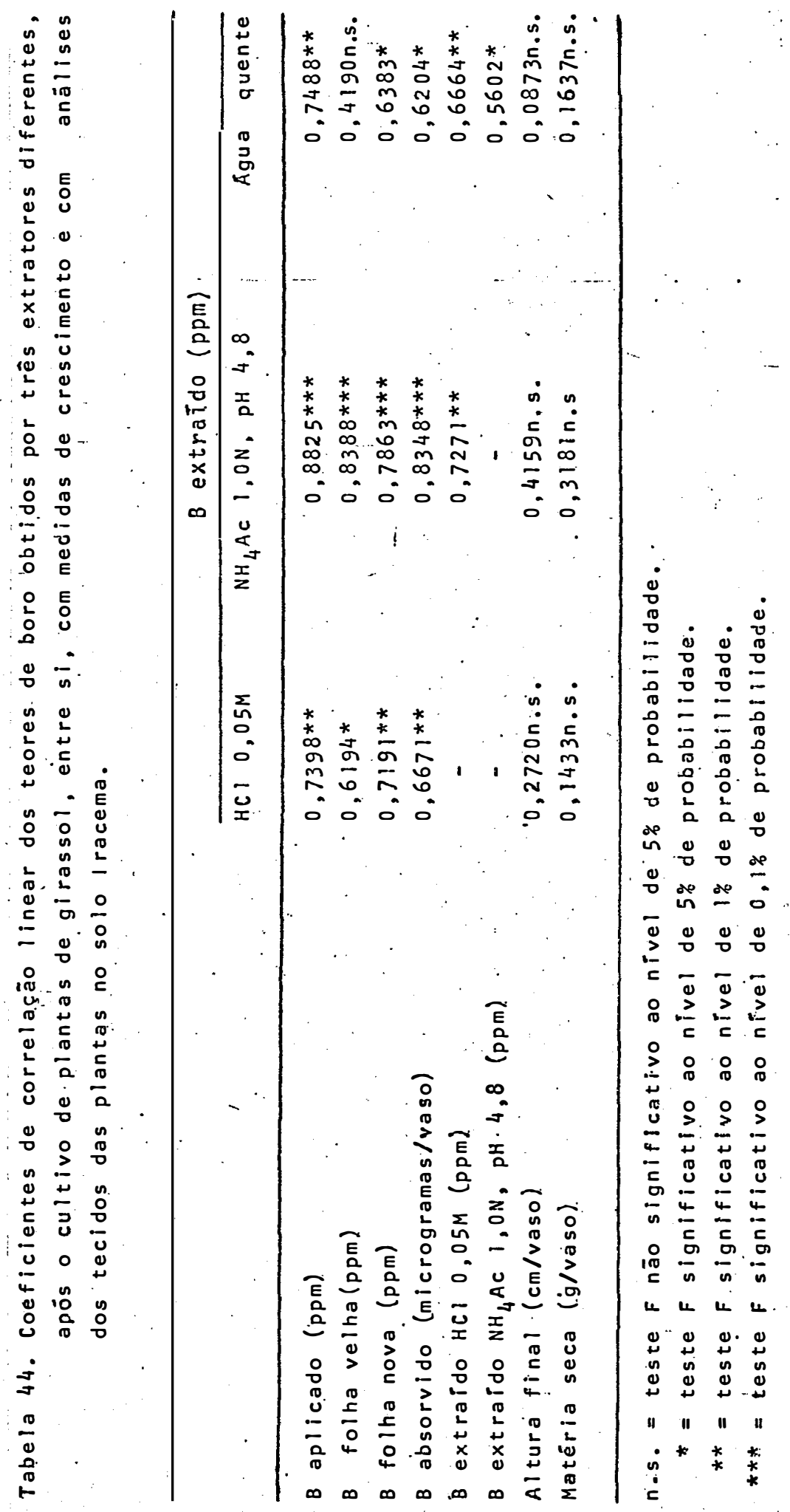

.88. 


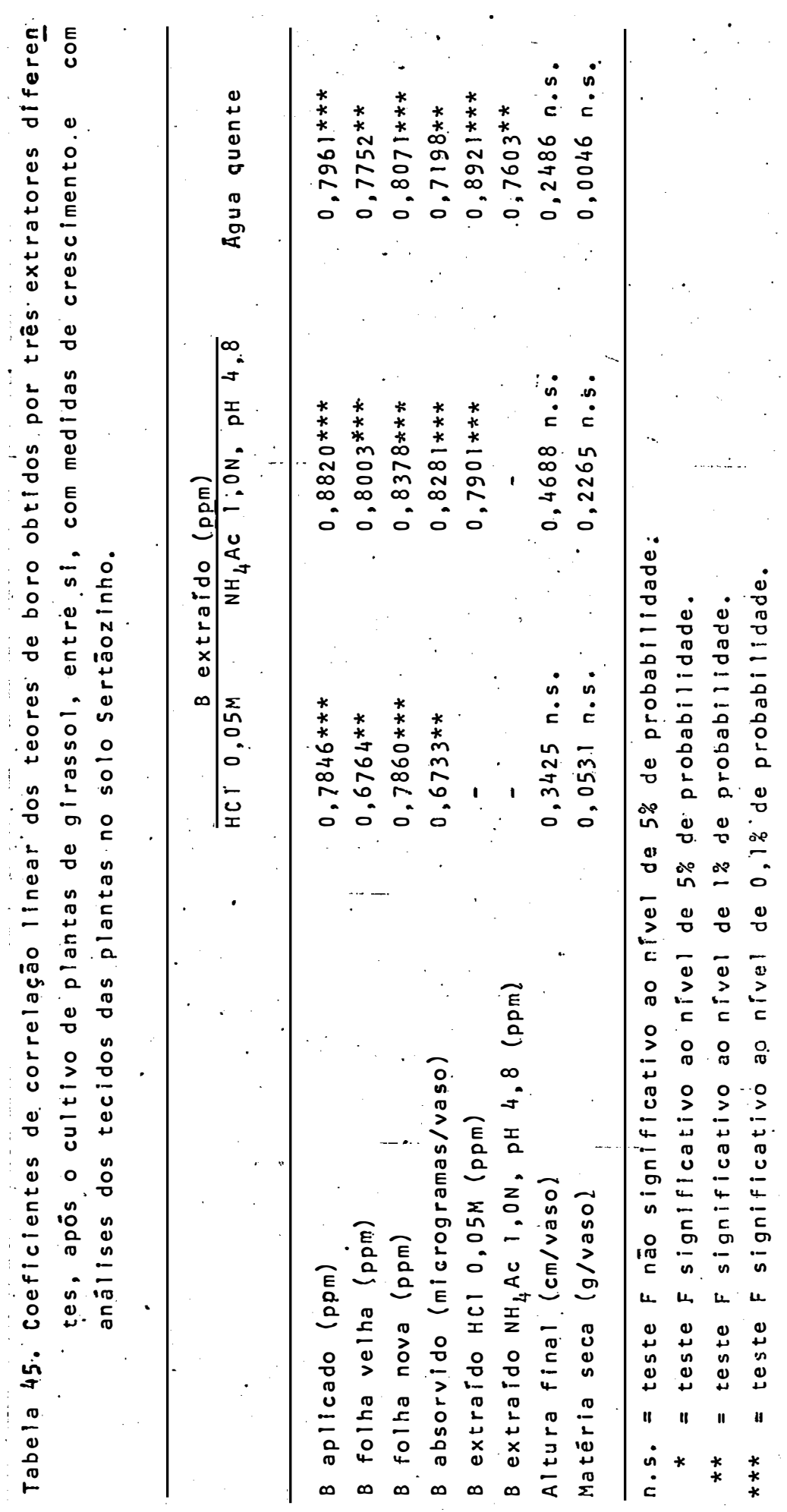

.89. 
.90.

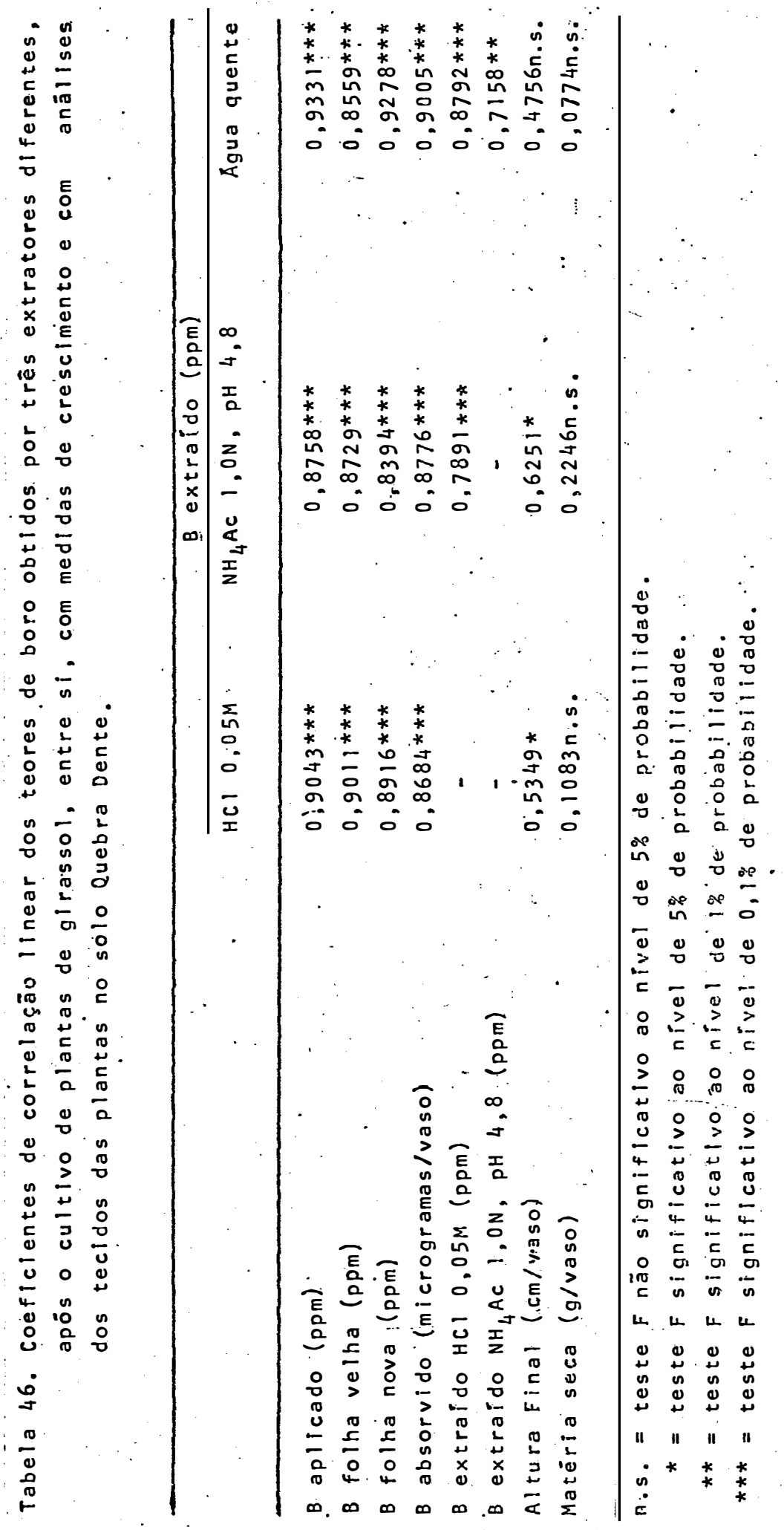




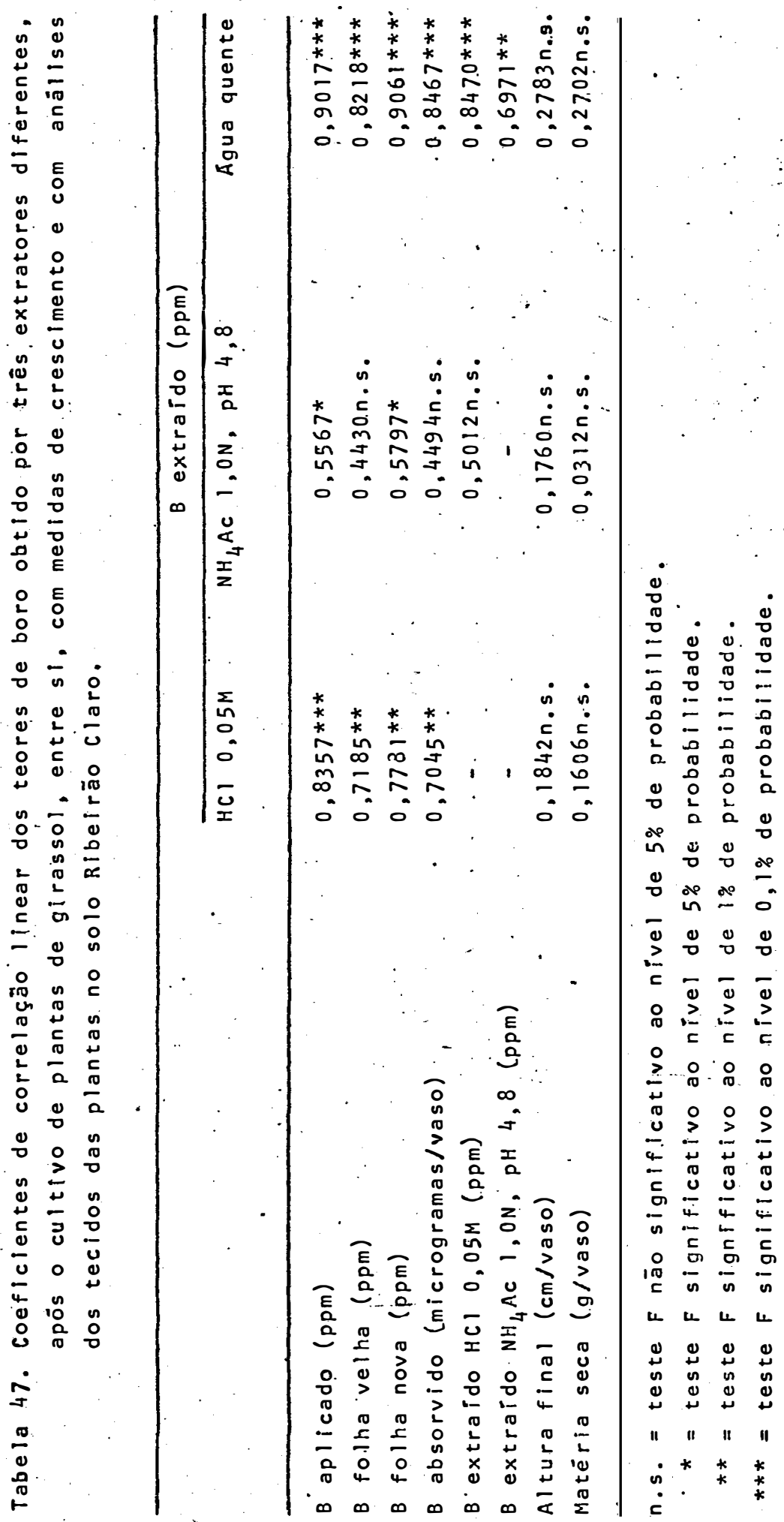


relações, o mesmo sendo válido para a quantidade de boro ab sorvida por vaso. As medidas de crescimento, produção de ma téria seca e altura final, também mostraram correlações mui to baixas e, em geral, não significativas comos teores fi nais de boro, não havendo um extrator que apresentasse melho res correlações. Apesar da variação existente nos coeficien tes de correlação entre os șolos estudados pode se concluir que com exceção do solo Luiz de Queiroz o HCl 0,05.M corre lacionou-se melhor com a água quente que o acetato de amônio $1,0 \mathrm{~N}, \mathrm{pH} \mathrm{4,8}$. 


\section{CONCLUSÕES}

- Das medidas de crescimento estudadas a altú ra das plantas foi a que melhor refletiu o estado nutricional das mesmas em relação ao boro, ao passo que o pesto da maté ria seca das raízes foi a medida de crescimento que pior re fletiu a disponibilidade de boro no solo.

- Os teores de fósforo, magnësio e enxofre di minuíram com o aumento da dose de boro nos solos com baixos teores deste micronutriente; com relação ao nitrogênio, potás sio, cālcio, zinco, cobre, ferro e manganês houve muita va riação conforme a parte da planta considerada.

- Com base na composição mineral às folhas no vas foram a parte da planta. mais sensível à disponibilidade 
de boro, seguidas pelas folhas velhas, por outro lado os caules e ráizes não se mostraram bons indicadores:da disponibilidade deste micronutriente.

- Houve em tódos os solos éfeito das doses de boro sobre os teores do micronutriente nas folhas, bem como sobre a quantidade de boro absorvida pelas plantas.

- Com relação à produção relativa de matēria seca para o HCl 0,05 M teores menores ou iguais a 110.31 ppm de B no solo são baixos, entre 0,31 a 0,50 ppm são médios e acima de 0,50 ppm são altos para o $\mathrm{NH}_{4} \mathrm{Ac} 1,0 \mathrm{~N}, \mathrm{pH} 4,8$ teores me nores ou iguais a $0,18 \mathrm{ppm}$ são baixos, entre $0 ; 18$ a $0,27 \mathrm{ppm}$ são médios e acima de 0,27 ppm são altos; para a ägua quente teores menores ou iguais a $0,26 \mathrm{pppm}$ são baixos, entre 0,26 a $0,41 \mathrm{ppm}$ são médios e acima de $0,41 \mathrm{ppm}$ são altos. Com relação à a tura relativa das plantas para O HCl $0,05 \mathrm{M}$ teores menores ou iguais a $0,36 \mathrm{ppm}$ são baixos, entre $0 ; 36$ a 0,49 ppm são mé diós e acima de $0,49 \mathrm{ppm}$ são altos; pana o $\mathrm{NH}_{4} \mathrm{Ac} 1,0 \mathrm{~N}, \mathrm{pH} \quad 4,8$ teores menores ou iguais a 0,18 ppm baixos, entre 0;18 a $0,25 \mathrm{ppm}$ são médios è acima de 0,25 ppm são altos; para a água quente teores menores ou iquais a. 0,32 ppm são baixos, entre 0,32 a 0,42 ppm são médios e acima.de 0,42 ppm são altos.

- Os três extratores estudados retiraram do solo apenas uma fração do boro disponível às plantas, sendo 
que a ägua quente foi o extrator que apresentou melhor compor tamento quando se comparou: o teor inicial com a quantidade de boro absorvida pelas plantas e com os teores do micronu triente nas folhas novas, que foram a parteda planta mais sensível ao nível de boro disponível no solo, vindo a seguir nos dois aspectos o HCl $0,05 \mathrm{M}$, enquanto. O $\mathrm{NH}_{4} \mathrm{AC} 1,0 \mathrm{~N}, \mathrm{pH} 4,8$ apresentou comportamento inferior aos dois mëtodos anteriores.

- O teor de boro nas folhas novas mostrou ser um índice melhor que os teores iniciais e finais de boro no solo, fornecidos pelos três extratores estudados, para ava liar o boro do solo disponível às plantas. Por outro lado so los de texturamais fina apresentaram maior quantidade de bo ro disponível que os de textura grosseira.

- Os teores de boro obtidos no final do ensa io pelos três extratores não se relacionaram de modo satisfá tório com as medidas de crescimento, não havendo um extrator que. apresentasse melhor comportamento. Quando se comparou os teores finais de boro obtidos com os três extratores e o teor do micronutriente nas folhas novas e velhas, bem como com a quantidade de boro absorvida por vaso não se pode concluir so bre qual extrator apresenta melhor comportamento, podendo-se dizer que o teor de boro disponível após o cultivo de plantas obtidos pelos três extratores praticamente não forneceram in formações sobre a disponibilidade de boro existente anterior 
mente ao cultivo.

- Tendo em vista o conjunto de resultados ob tidos conclui-se que a água quente foi o melhor extrator, se guida pelo $\mathrm{HCl} 0,05 \mathrm{M}$ sendo. $\mathrm{NH}_{4} \mathrm{AC}, 1,0 \mathrm{~N}, \mathrm{pH} 4,8$ o extrator de pior comportamento. 
6. LiTERATURA CITADA

BAKER, A.S. e R.L. COOK, 1956. Need of boron fertilization for alfalfa in Michigan and methods for determining this need. Agronomy Journal." Madison, 48:564-568.

BAKER, A.S. e R.L. COOK, 1959. Greenhouse studies on alfalfa with soil type, soil reaction and borax fertilization as variables. Agronomy Journal, Madison, 51:1-4.

BAKER, A.S., 1971. Relation between available boron, and boron extracted from soils by hot water or phosphoric acid. Communications in Soil Science and Plant Analysis. New York, 2: $311-320$. 
BERGER, K.C. e E. TRUOG, 1939. Boron determination in soils and plants. Industrial and Engineering Chemistry. Easton, 11: $540-545$.

BERGER, K.C.: e E. TRUOG, 1940. Boron defici.ences as revealed by plant and soil tests. Journat of the American Society of Agronomy. Genova, 32:29.7-301.

BERGER, K.C., 1949. Boron in soils and crops. Advances in Agronomy. New York, $1: 321-351$.

BLAMEY, F.P.C.; D. MOULD e J. CHAPMAN, 1979: Critical boron concentrations: in plant tissues of two sunflower cultivars. Agronomy Journal. Madison, 71:243-247.

BRASIL SOBRINHO, M.O.C., 1965. Levantamento do teor de boro em alguris solos do estado de São Paulo. ESALQ/USP, 135 p. (Tese de Livre Docência).

BRAY, R.H., 1948. Correlation of soil tests with crop response to added fertilizers and with fertilizer requirements. In:'KITCHEN, H.B., ed. Diagnostic techniques for soils and crops. Washington, D.C., The American Potash Institute, p. $53-86$.

CASAGRANDE, J.C., 1978. o boro em solos do município de Pira cicaba. ESALQ/USP, 122 p. (Dissertação de Mestrado). 
.99.

CATANi, R.A. e J.R. GALlo, 1955. Avaliação da exigência em calcário dos solos do estado de são Paulo, mediante corre lação entre o pH e a porcentagem de saturação em bases. Revista da Agricultura. Piracicaba, 30:49-60.

CATANI, R.A. e A.0. JACINTHO, 1974. Avaliąão da Fertilidade do Solo. Métodos de Anälise. São Paulo, Editora Agronômi ca Ceres. $61 \mathrm{p}$.

COPE, J.T. e R.D. ROUSE, 1973. Interpretation of soil test results. In: WALSH, L.M..J.D. BEATON, eds. Soil testing and plant analysis. Madison, Soil science Society of Ameriça, p. 35-66.

DIBLE, W.T.; E. TRUOG e K.C. BERGER, 1954. Boron determination in soils and plants by simplified curcumin procedure. Analytical Chemistry. New York, 26:418-421.

ELLIOTT, G.C. e P.V. NELSON, 1981. Acutë boron toxicity in Begonia hiemalis. Commications in soir science and plant Analysis. New York, 12:775-783.

GUPTA, U.C., 1967. A simplified method for determining hot-water soluble boron in podzol soils. Soil science. New Brunswick, 103:424-428.

GUPTA, U.C., 1968. Relationship of total and hot water soluble boron, and fixation of added boron to properties of podzol soils. Soil Science Society of America Proceedings Madison, $32: 45-48$. 
GUPTA, S.K. e J.W.B. STEWART, 1975. The extraction and determination of plant available boron in soils. Schweizerishe landwirtschaftiche Forschung saskatoon, $14: 153-169$.

GUPTA, U.C. e J. MacLEOD, 1977. Influence of calcium and magnesium sources on boron uptake and yield of alfalfa and rutabaga as related to soil pH. Soil Science. Baltimore, $124: 279-284$.

HANWAY, J.J., 1973. Experimental methods for correlating and calibrating soil tests. In: KALSH, L.M. e J.D. BEATON, eds. Soil testing and plant analysis. Madison, Soil Science Society of America, p. 55-66.

HIROCE, R., J.R. GALLO e S.A. NOBREGA, 1971. Defíciência de boro em batatinha cultivada em solo orgânico do Vale do Paraíba. Bragantia. Campinas, 30 (nota n? 2); V-VII.

HOROWITZ, A. E H.S. DANTAS, 1973. Borodisponível nos solos da zona litoral-mata de Peirnambuco. Pesquisa Agropecuária Brasizeira. Sèrie Agronomia. Rio de Janeiro, 8:163-168.

KLLMER, V.J. e L.T. ALEXANDER, 1949. Methods of making mechanical analysis of soil. Soil Science. New Brunswick, $\underline{68}: 15-24$. 
KRUG, F.J.; H. BERGAMIN FILHO; E.A.G. ZAGATTO E S.S. JORGEN SEN, 1977: Rapi.d de termination of sulphate in natural waters and plant digests by continuous flow injection turbidimetry. Analyst. London, 102:503-508.

MALAVOLTA, E. 1981. Manual de Quimica Agricola-Adubos e Adubąão. São Paulo, Editora Agronômica Ceres. 596 p.

MAZAHERI, A. 1976. Preparation and use of azomethine-H for colorimetric determination of boron. Communications in Soil Science and Plant Analysis. New York, 7:331-334.

MCCLUNG, A.C. e J.E. DAWSON, 1950. Some studies on the behavior of soil boron under cropping. Soil science Society of America Proceedings. Madison, 15:268-272.

MELSTED, S.W. e T.R. PECK, 1973. The principles of soil testing. In: WALSH, L.M. e J.D. BEATON, eds. Soil testing and plant analysis. Madison, soll science Society of America, p. 13-20.

MESQUITA FILHO, M.V. e S.A. OLIVEIRA, 1984. Influência do boro na produção de matēria seca da batata. Horticultura brasileira. Brasilia, 2 : $9-11$. 
OBUKHOV, A.I., 1968. Content and distribution of minor elements in the soils of the dry tropical zone of Burma. Soviet Soir Science Madison, 1:224-233.

OKAZAKI, E. E T.T. CHAO, 1968.; Boron adsorption and desorption by some hawaiian soils. Soit Science. New Brunswick, 105:255259 .

PETERSON, L.A. e R.C. NEWMAN, 1976. Influence of soil pH on the availability of added boron." Soir science society of American Journal. Madison, 40:280-282.

PONNAMPERUMA, F.N.; M.T. CAYTON E R.S. LANTIN, 1981. Dilute hydrochloric acid as an extractant for available zinc, copper and boron in rice soils: Plant and soil. New York, 61:297-310.

RAIJ, B. van, 1974. Calibração do poțāssio trocável èm" solos para feijão, algodão e cana-de-açücar. Ciência $e$ Cuztura. São Paule, 2€:575-579.

RAIJ, B. van, 1981. Avaliação da fertilidade do solo. Piraci caba, Instituto da Potassa (EUA-Suiça). $142 \mathrm{p}$.

RANZANI, G.; O. FREIRE e T. KINJ0, 1966. Carta de Solos do municipio de Piracicaba. Centro de Estudos de Solos, ESALQ-USP, Piracicaba, 85 p. 
.103.

REISENAUER, H.M.; L.M. WALSH e R.G. HOEFT, 1973. Testing soils for sulphur, boron, molybdenum and chlorine. In: WALSH, L.M. e J.D. BEATON, eds. Soil testing and plant analysis. Madison, Soil Science Society of America, p. 173-200.

ROUSE, R.D., 1968. Soil test theory and calibration for cotton corn, soybeans and coastal bermuda grass. Bulletin. Alabama Agricultural Experiment Station, Auburn, n: 375, $67 \mathrm{p}$.

RUSSEL, D.A., 1957. Boron and soil fertility. In: STTEFFERUD; A., ed. The Yearbook of Agriculture. Washington, D.C., The United States Department of Agriculture, p. 121-128.

SARRUGE, J.R. e H.P. HAAG, 1974. Analịses químicas em plantas. Piracicaba, ESALQ-USP. 56 p.

SCHUSTER, C.E. E R.E. STEPHENSON, 1940. Sunflower as an indicator plant of $B$ deficiency in soils. Joumal of the American Society of Agronomy. New York, 32:607-621.

WALMSLEY, D.; I.T. TWYFORD e I.S. CORNFORTH, 1971. An evaluation of soil analysis methods, for nitrogen, phosphorus and potassium, using banana. Tropical Agriculture. Trinidad, 48:141-145. 
.104.

WALSH, L.M. e J.D. BEATON, 1973. Opportunities to improve soi.l testing programs. In: WALSH, L.M. e J.D. BEATON, eds. Soil testing and plant analysis. Madison, soil Science Society of America, $p .1-11$. 